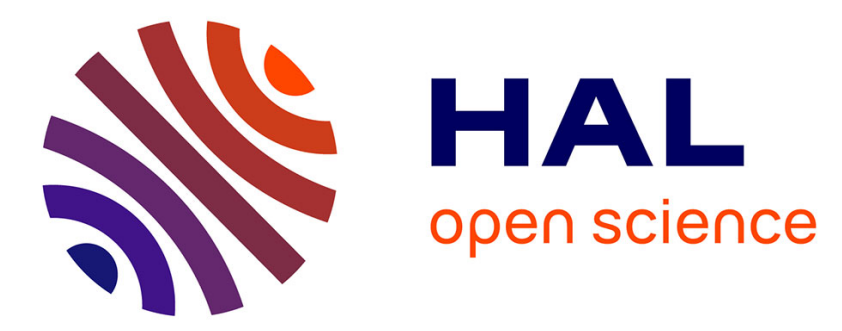

\title{
Organic matter cracking: A source of fluid overpressure in subducting sediments
}

Hugues Raimbourg, Régis Thiery, Maxime Vacelet, Vincent Famin, Claire Ramboz, Mohammed Boussafir, Jean-Robert Disnar, Asuka Yamaguchi

\section{- To cite this version:}

Hugues Raimbourg, Régis Thiery, Maxime Vacelet, Vincent Famin, Claire Ramboz, et al.. Organic matter cracking: A source of fluid overpressure in subducting sediments. Tectonophysics, 2017, 721, pp.254-274. 10.1016/j.tecto.2017.08.005 . insu-01609033

\section{HAL Id: insu-01609033 \\ https://hal-insu.archives-ouvertes.fr/insu-01609033}

Submitted on 3 Oct 2017

HAL is a multi-disciplinary open access archive for the deposit and dissemination of scientific research documents, whether they are published or not. The documents may come from teaching and research institutions in France or abroad, or from public or private research centers.
L'archive ouverte pluridisciplinaire HAL, est destinée au dépôt et à la diffusion de documents scientifiques de niveau recherche, publiés ou non, émanant des établissements d'enseignement et de recherche français ou étrangers, des laboratoires publics ou privés.

\section{(1) (1) $\$$}

Distributed under a Creative Commons Attribution - NonCommercial - NoDerivatives 44.0 


\section{Accepted Manuscript}

TEGTONOPHYSICS

Organic matter cracking: A source of fluid overpressure in subducting sediments

Hugues Raimbourg, Régis Thiéry, Maxime Vacelet, Vincent Famin, Claire Ramboz, Mohammed Boussafir, Jean-Robert Disnar, Asuka Yamaguchi

PII:

S0040-1951(17)30324-4

DOI: doi: $10.1016 /$ j.tecto.2017.08.005

Reference: TECTO 127579

To appear in:

Tectonophysics

Received date:

30 September 2016

Revised date:

14 May 2017

Accepted date:

3 August 2017

Please cite this article as: Hugues Raimbourg, Régis Thiéry, Maxime Vacelet, Vincent Famin, Claire Ramboz, Mohammed Boussafir, Jean-Robert Disnar, Asuka Yamaguchi , Organic matter cracking: A source of fluid overpressure in subducting sediments. The address for the corresponding author was captured as affiliation for all authors. Please check if appropriate. Tecto(2017), doi:10.1016/j.tecto.2017.08.005

This is a PDF file of an unedited manuscript that has been accepted for publication. As a service to our customers we are providing this early version of the manuscript. The manuscript will undergo copyediting, typesetting, and review of the resulting proof before it is published in its final form. Please note that during the production process errors may be discovered which could affect the content, and all legal disclaimers that apply to the journal pertain. 
Organic matter cracking: a source of fluid overpressure in subducting sediments

Hugues Raimbourga,b,c, Régis Thiéryd, Maxime Vacelete, Vincent Famin, Claire Rambozi,b,c, Mohammed Boussafiri,b,c, Jean-Robert Disnar,a,c, Asuka Yamaguchi ${ }^{\mathrm{a}}$

(a) Univ. d'Orléans, ISTO, UMR 7327, 45071 Orléans, France

(b) CNRS, ISTO, UMR 7327, 45071 Orléans, France

(c) BRGM, ISTO, UMR 7327, BP 36009, 45060 Orléans, France

(d) LMV, UMR 6524, CNRS/Clermont Univ., Clermont-Ferrand, France

(e) Centre de Géosciences, MINES ParisTech, Fontainebleau, France

(f) Laboratoire Géosciences Réunion, Univ. de La Réunion, IPGP, Sorbonne Paris Cité, UMR 7154 CNRS, Saint-Denis, La Réunion, France.

(g) Atmosphere and Ocean Research Institute, Tokyo Univ., 5-1-5 Kashiwanoha, Kashiwa, Chiba 277-8564, Japan

Corresponding author: hugues.raimbourg@univ־orleans.fr 


\section{1 -Abstract}

The pressure of deep fluids in subduction zones is a major control on plate boundary strength and earthquake genesis. The record, by methane-rich fluid inclusions, of large $(\sim 50-100 \mathrm{MPa})$ and instantaneous pressure variations in the Shimanto Belt (Japan) points to the presence of large fluid overpressure at depth $\left(300-500 \mathrm{MPa}, \sim 250^{\circ} \mathrm{C}\right)$. To further analyze the connection between methane and fluid overpressure, we determined with Rock-Eval the potential for a worldwide selection of deep seafloor sediments to produce methane as a result of organic matter (OM) cracking due to temperature increase during subduction. The principal factor controlling the methanogenesis potential of sediments is OM proportion, while OM nature is only a subordinate factor. In turn, OM proportion is mainly controlled by the organic terrigenous input. Considering a typical sediment from ocean-continent subduction zones, containing $0.5 w t \%$ of type III OM, cracking of OM has two major consequences: (1) Methane is produced in sufficient concentration as to oversaturate the pore-filling water. The deep fluid in accretionary prisms is therefore a mechanical mixture of water-rich and methane-rich phases; (2) $\mathrm{CH}_{4}$ production can generate large fluid overpressure, of the order of several tens of $\mathrm{MPa}$, The conditions for these large overpressure are a low permeability of the upper plate $\left(<2.10^{-21} \mathrm{~m}^{2}\right)$ and décollement zone $\left(<10^{-18} \mathrm{~m}^{2}\right)$, which may 
be prevailing in the depth domain $(\mathrm{z}>10 \mathrm{~km})$ where OM thermal cracking occurs. At these depths, OM thermal cracking appears as a source of overpressure larger than the last increments of smectite-to-illite reaction. Such large overpressures play potentially a role in facilitating slip along the plate interface. Conversely, the scarcity of earthquakes in ocean-ocean subduction zones such as Marianna or Barbados may be related to the low influx of detrital $\mathrm{OM}$ and the limited methane/overpressure generation at depth.

\section{2-Introduction}

Fluid pressure is often considered as one of the major control on brittle deformation, through its effect on yield stress in friction laws. Indeed, seismological studies point to large overpressure of fluid within the upper part of the subducting slab or along the plate interface in several subduction zones generating large earthquakes such as Costa Rica (Audet and Schwartz, 2013), Chile (Moreno et al., 2014) or southwestern Japan (Kato et al., 2010). The relationship between overpressure amplitude and seismogenesis is nevertheless not straightforward, as can be illustrated near the rupture zone of the 2010 Maule earthquake in Chile: fluid pressure is near lithostatic everywhere along the subduction interface but the zones of seismic interlocking correlate with the lowest overpressure of fluid (Moreno et al., 2014). Similarly, the mechanical role of fluid pressure in coseismic rupture is complex: Fluid thermal pressurization is a possible 
process of dynamic weakening (Wibberley and Shimamoto, 2005), while fluid pressure decrease due to earthquake-induced fault damaging and dilatancy results in strengthening.

The question of the origin and the amplitude of the overpressure has been thoroughly studied in the context of basins and oil generation. In such contexts, rock loading as a result of burial is often considered as the principal factor for the increase in pore fluid pressure (Maubeuge and Lerche, 1994; Osborne and Swarbrick, 1997; Tingay et al., 2009; Yu and Lerche, 1996). Other processes, such as aquathermal expansion, clay dehydration or organic matter cracking and oil/gas generation can also contribute to forming overpressure if the reservoir is sealed (Osborne and Swarbrick, 1997). Amongst these processes, gas generation is in theory very efficient (Barker, 1990; Ungerer et al., 1981) and has been proposed as the cause for the overpressure in several instances (Cobbold et al., 2004; Michael and Bachu, 2001).

In subduction zone settings, several processes have been investigated as possibly contributing to the generation of overpressures (see the review in Saffer and Tobin (2011)). If disequilibrium compaction is the main process operating at shallow depths $(\leq 1-2 \mathrm{~km})$, responsible for example for the large porosity in underthrusted sediments in Nankai subduction zone (Screaton et al., 2002; Tobin and Saffer, 2009), other processes 
may take over at larger depth and temperatures. Prograde metamorphic reactions, involving primarily the clay minerals abundant in the sediments (e.g. smectite to illite or smectite to chlorite reactions) result in general in releasing water from the minerals and possibly contribute to fluid overpressure (Kameda et al., 2011; Saffer and Tobin, 2011). Similarly, hydrocarbon generation from organic matter cracking has a potential impact on fluid pressure, exactly like in basinal settings (Moore and Vrolijk, 1992).

Smectite-to-illite reaction occurs principally in the range $50-150^{\circ} \mathrm{C}$ (Pytte and Reynolds, 1989; Saffer and Tobin, 2011). In hot subduction zone settings such as the Nankai accretionary prism, the reaction is already significantly advanced at depth $\sim 1 \mathrm{~km}$ below seafloor, in the lower part of drilled section (Saffer and McKiernan, 2009). The temperature window where oil and gas generation occurs is a function of the nature of the organic matter buried as well as of the burial rate (Bordenave, 1993; Ungerer et al., 1986). As, in worldwide subduction zones, OM is principally of type III (terrestrial origin) (Larue, 1991), and the burial rate of sediments is "high", with respect to oil basin standards, $\mathrm{OM}$ thermal cracking starts in the temperature range $100-150^{\circ} \mathrm{C}$, i.e. higher than clay reactions. The associated low porosity-low permeability environment prevents fluid leakage and is much favorable to overpressure buildup and preservation (Neuzil, 1995). 
To study OM thermal cracking requires to reach depths beyond drilling in active margins: the $150^{\circ} \mathrm{C}$ isotherm is located for example at $\sim 10 \pm 2 \mathrm{~km}$ depth in the Nankai accretionary prism (Marcaillou et al., 2012), a relatively "hot" type of subduction zone, and at larger depths in Costa Rica or Tohoku-Oki (Harris et al., 2010; Kimura et al., 2012). Therefore, for such $\mathrm{T}$ domain the only reliable source of information lies in the inner domains of fossil accretionary prisms eroded and exhumed to the surface. In the three well-studied geological examples of the Franciscan Complex (Dalla Torre et al., 1996), Kodiak Island (Vrolijk et al., 1988) and the Shimanto Belt (Raimbourg et al., 2014b), fluid inclusions made of a mixture of salt water and methane, trapped in quartz for $\mathrm{T} \sim 250^{\circ} \mathrm{C}$, have been described. The consistent occurrence of this mixture shows that methane is sufficiently abundant to oversaturate the pore-filling water and to be exsolved as a free phase in this temperature range. This evidence shows qualitatively that the permeability was sufficiently low as to inhibit the migration of hydrocarbons and gas at the depths of OM thermal cracking.

In this work we explore further the connection between OM thermal cracking and overpressure in subduction zone. Similarly to Larue (1991), we propose to analyze fossil and modern subduction zone sediments in parallel. First, the microthermometric and RockEval analyses of material from the deep domains of a fossil accretionary prism, the 
Shimanto Belt in Japan, are used to get insights into the nature and concentration of $\mathrm{OM}$ and the overpressure recorded in the fluid. Second, the RockEval analysis of worldwide samples is carried out as an input to an analytical model of OM thermal cracking and fluid overpressure generation in subducted sediments. Finally, we discuss on the basis of this model the possible connections between OM thermal cracking, overpressure and seismogenesis in subduction zones.

\section{3-Methods}

\subsection{Microthermometric measurements on fluid inclusions}

Microthermometric measurements were carried out on fluid inclusions contained in quartz veins. The selected quartz fragments were placed on a $200 \mu \mathrm{m}$-thick, $1.6 \mathrm{~cm}^{-}$wide rounded glass window placed on the silver block of the Linkam heating-cooling stage. Phase changes in the inclusions were observed using an Olympus BHS microscope equipped with a x80 ULWD Olympus objective and recorded by a Marlin black and white camera (CMOS 2/3" sensor, resolution $1280 \times 1024$ pixels $^{2}$, pixel size $6.7 \mu \mathrm{m}$ ). Temperature was measured using a class B Pt 100 thermistance. Temperature is sampled every $\sim 300 \mathrm{~ms}$ by a Eurotherm 902 controller which allows analogic output. The temperature cycles of the stage (heating - cooling rate and temperature steps) are controlled using a LabVIEW ${ }^{\circledR}$ computer program. In the vicinity of the phase transitions, 
we chose slow heating rates of $\sim 1^{\circ} \mathrm{C} / \mathrm{mn}$.

The stage was calibrated between $-56.6^{\circ}$ and $573^{\circ} \mathrm{C}$ against eight reference temperatures. The standards used were either natural and synthetic fluid inclusions (melting point of $\mathrm{CO}_{2}$ at $-56.6^{\circ} \mathrm{C}$; melting point of ice: $0^{\circ} \mathrm{C}$ ) or solids: ceramics (solid solid transitions at $37^{\circ}$ and $47^{\circ} \mathrm{C}$ in $\mathrm{CsPbCl}_{3}$ and at $180^{\circ} \mathrm{C}$ in $\mathrm{Pb}_{3}\left(\mathrm{PO}_{4}\right)_{2}$; salt: b/g $\rightarrow$ a transition at $147^{\circ} \mathrm{C}$ in $\mathrm{AgI}$ and subsequent melting at $557^{\circ} \mathrm{C} ;$ mineral: $\mathrm{a} \rightarrow \mathrm{b}$ transition in quartz at $573^{\circ} \mathrm{C}$. Based on the calibration, the precision on measured temperatures is around $\pm 1^{\circ} \mathrm{C}$ over the investigated T-range.

\section{2-Analysis of organic matter}

\subsubsection{Rock-Eval analysis}

Rock-Eval pyrolysis, a classical method for petroleum source rocks, was used to determine the amount and quality of OM in sediments. Depending on the estimated OM content, 50 to $100 \mathrm{mg}$ of dried sediment was used for Rock-Eval6® (Vinci Technologies, Rueil Malmaison) analysis. The inert pyrolysis program (oven 1) starts with an isothermal stage of $2 \mathrm{~min}$ at $200^{\circ} \mathrm{C}$. Then, the pyrolysis oven temperature is raised at $30^{\circ} \mathrm{C} \cdot \mathrm{min}^{-1}$ up to $650^{\circ} \mathrm{C}$, and held 3 minutes at this temperature. The oxidation phase (oven2) starts by an isothermal stage at $400^{\circ} \mathrm{C}$ then a ramp at $30^{\circ} \mathrm{C} \cdot \mathrm{min}^{-1}$ up to $850^{\circ} \mathrm{C}$, with a hold for $5 \mathrm{~min}$. 
The significance of the now classical Rock-Eval parameters was explained by Espitalié et al. (1977). The Rock-Eval parameters used for this study are the following: The S1 and S2 parameters represent respectively "free" thermovaporized hydrocarbon (HC) and "linked" pyrolysed HC produced during the inert pyrolysis (in mg HC.g-1 sample). $\mathrm{S} 3$ parameter represents the $\mathrm{CO}$ and $\mathrm{CO} 2$ released during this inert pyrolysis (oven1). $\mathrm{S} 4$ parameter represents the $\mathrm{CO}$ and $\mathrm{CO} 2$ produced during the oxidative pyrolysis (oven2). We deduce from the parameters S1, S2, S3 and S4 the Total Organic Carbon (TOC, wt\%). The TOC is also the sum of the Pyrolyzed Carbon (PC, deduced from inert pyrolysis parameters) and Residual Carbon (RC, deduced from oxidative pyrolysis parameters). The Hydrogen Index (HI, or mg HC.g-1 TOC) is the amount of HC released during pyrolysis relative to TOC. The Oxygen Index (OI, or $\mathrm{mg} \mathrm{CO}_{2 . \mathrm{g}^{-1}} \mathrm{TOC}$ ) is a measure of the oxygen content of the $\mathrm{OM}$ calculated from the amounts of $\mathrm{CO}$ and $\mathrm{CO}_{2}$ released during pyrolysis and normalized to TOC. Note that for TOC below $0.1 \mathrm{wt} \%$, the values of HI and OI have to be considered with caution. Unlike previous instruments, Rock-Eval6® measures the exact temperature experienced by the sample. The value determined at the top of the S2 peak is called TpeakS2. Tmax is a well-established OM thermal maturity indicator in ancient sediments.

\subsubsection{Estimation of methane productivity}


Methane productivity is defined as the potential for a sediment rock volume to generate

methane by cracking its whole OM stock into methane. Such virtual thermogenic production of methane can be estimated from the generic reaction:

$$
\text { initial organic matter } \rightarrow \text { residual organic matter }+ \text { methane }
$$

or

$$
\mathrm{C}_{x} \mathrm{H}_{y} \rightarrow \mathrm{C}_{x \prime}+\mathrm{nCH}_{4}
$$

The initial stock of organic carbon $C_{x}$ of subsurface sediments (i.e. $<1 \mathrm{~km}$ below sea floor) is estimated from their TOC, while initial hydrogenation of OM (i.e. the atomic ratio $\frac{\mathrm{y}}{\mathrm{x}}=\mathrm{H} / \mathrm{C}_{\mathrm{atom}}$ ) is derived from their Rock-Eval HI (Espitalié et al., 1977). The mass proportion (relative to unit rock mass) of hydrogen is given by $\frac{T O C x \mathrm{H} / \mathrm{C}_{\mathrm{atom}}}{12}$, the mass proportion of methane is thus $4 \frac{T O C \times \mathrm{H} / \mathrm{C}_{\mathrm{atom}}}{12}=\frac{T O C \times \mathrm{H} / \mathrm{C}_{\mathrm{atom}}}{3}$. Considering, for low porosity rocks, a density of $2.710^{3} \mathrm{~kg} / \mathrm{m}^{3}$, the methane productivity (in $\mathrm{kg} / \mathrm{m}^{3}$ of rock) is given by $27 x \frac{\operatorname{TOC} x \mathrm{H} / \mathrm{C}_{\mathrm{atom}}}{3}$.

\section{4-Fossil record of the composition and pressure of deep subduction}

\section{fluids}

\subsection{Choice of the field target}

With the Franciscan Complex or Kodiak Island, the Shimanto Belt is one of the most-studied examples of accretionary prism, where exhumed, fossil structures are 
used to interpret the deep domains of modern subduction margins. In particular, the inner domains of the Shimanto Belt have been used to study the nature of the deep fluids (Kondo et al., 2005; Raimbourg et al., 2014b; Raimbourg et al., 2015; Sakaguchi, 1999; Yamaguchi et al., 2012) or the features of the deformation (Okamoto et al., 2006; Raimbourg et al., 2014a). The Hyuga tectonic mélange is interpreted as having formed as a result of shearing along the plate interface at depth (Raimbourg et al., 2014a). Consequently, we carried out microthermometric measurements on fluid inclusions and a RockEval study of organic matter from the Hyuga Tectonic mélange, to analyze the physico-chemical properties of the fluid at the depths of organic matter cracking along the plate interface.

\subsection{Occurrences of methane-rich fluid inclusions}

In the Hyuga Tectonic mélange (Fig. 1), pervasive quartz veining occurred throughout rock evolution, in particular for peak burial conditions of $300-500 \mathrm{MPa}$ and $\sim 250-270^{\circ} \mathrm{C}$ and through the near-isothermal rock exhumation (Raimbourg et al., 2014b; Toriumi and Teruya, 1988). All fluid inclusions are made of a mixture of salt water and methane, in variable proportions. While in most of the Hyuga mélange unit, only one kind of water-rich fluid inclusions are present, two types of inclusions, namely water-rich and methane-rich ones, could be observed along the eastern coast, pointing to the 
coexistence of two immiscible fluids at depth (Raimbourg et al., 2014b).

Methane-rich fluid inclusions are present in non-deformed quartz veins, postdating the metamorphic climax and hence trapped along the retrograde path. The inclusions are organized as secondary planes of inclusions (Fig. 1), corresponding to healed fracture planes and recording therefore the P-T conditions during a short time interval.

\subsection{Results of microthermometric measurements}

We measured the temperature of homogenization of the methane-rich phase in several fluid inclusion planes (Fig. 2), from which the density of the trapped fluid can be calculated and an isochoric line can be drawn with the Loner software (Bakker, 2009).

The fluid P-T conditions of trapping can then be inferred from the fact that the rock was exhumed isothermally and that there is no evidence for a large rock-fluid discrepancy in temperature: trapping $\mathrm{P}-\mathrm{T}$ conditions correspond to the intersection of the isochore with the $\mathrm{T}=250^{\circ} \mathrm{C}$ isotherm.

Reproducing the procedure for each fluid inclusion in a given plane yields the range in fluid pressure during the short time lapse for the fracture to heal. A difference in $\mathrm{T}_{\mathrm{h}}$ of $10^{\circ} \mathrm{C}$ converts into a difference in trapping pressure of $\sim 50 \mathrm{MPa}$. Considering for each fracture in Fig. 2 the range of variations in homogenization temperatures, in most cases the width of $\mathrm{T}_{\mathrm{h}}$ distribution is $\sim 10^{\circ} \mathrm{C}$, but it can be as large as $\sim 20^{\circ} \mathrm{C}$. Accordingly, 
fractures are characterized by large, of the order of $\sim 50-100 \mathrm{MPa}$, variations in the trapping pressure of the methane-rich fluid.

\section{4-Results of RockEval analysis of organic matter}

The amount of carbon released during pyrolysis ( $\mathrm{S} 1$ and $\mathrm{S} 2$ peaks, or $\mathrm{PC}$ ) is extremely low in all samples, i.e. less than $0.1 \mathrm{mg} / \mathrm{g}$ of rock (Tab. 1). In contrast, the samples contains a small, but significant amount of refractory carbon, estimated during the oxidation stage (S3 and $\mathrm{S} 4$ peaks, or $\mathrm{RC}$ ). These features show that Hyuga Tectonic Mélange rocks are very mature, i.e. the OM initially present in the Hyuga Tectonic Mélange rocks has already been cracked and remains as carbon assemblages. This maturity is in agreement with paleotemperatures as large as $\sim 250^{\circ} \mathrm{C}$ experienced during burial (Kondo et al., 2005; Mukoyoshi et al., 2009; Palazzin et al., 2016).

The average content of $\mathrm{OM}$ in the rocks is $0.37 \mathrm{wt} \%$ (column TOC) and ranges between virtually no OM up to relatively large concentrations (0.6 wt\%) (Tab. 1). The TOC is similar in samples near the coast (yellow samples), where methane-rich fluid inclusions are present, to other samples of the Hyuga mélange. This average OM content is reduced from the original content in unmetamorphosed sediments by an amount corresponding to the hydrocarbons produced during cracking.

Considering a typical HI of 100 for pristine, subduction zone sediments (Fig. 5), yields 
an original atomic ratio $\mathrm{H} / \mathrm{C}_{\text {atom }}$ of 0.6 (Espitalié et al., 1977). Equation (1) can then be rewritten:

$$
\mathrm{C}_{x} \mathrm{H}_{0.6 x} \rightarrow \mathrm{C}_{0.85 x}+0.15 x \mathrm{CH}_{4}
$$

The average content of $0.37 \mathrm{wt} \%$ of refractory carbon converts into $0.46 \mathrm{wt} \%$ of initial TOC. Similarly, considering the sample richest in OM where we actually observed methane-rich fluid inclusions (sample 102), its residual TOC of $0.59 \mathrm{wt} \%$ converts into $0.73 w t \%$ of initial (=pre-cracking) carbon.

\section{5-Nature and concentration of OM in modern subducting}

\section{sediments}

To analyze the cracking of $\mathrm{OM}$ and the associated methane production in subducting sediments, we analyzed with Rock-Eval the relative proportions of Carbon, Hydrogen and Oxygen in the OM stock in various modern subduction zone sediments.

\subsection{Choice of the subduction zones and tested material}

To analyze the fate of subducted organic matter, we selected DSPD/ODP/IODP core samples of sediments on top of subducting plates and bound to be subducted as part of the slab (Fig. 3 and 4). We chose several zones worldwide, encompassing the variety of seismic and structural features of subduction zones. First, the different zones can be discriminated according to the presence (Costa Rica, NE Japan, Nankai, Alaska, 
Cascadia) or absence (Barbados, Marianna) of historical record of large magnitude earthquakes along the plate interface (Heuret et al., 2011; Kodaira et al., 2000; Lay et al., 2011; Yue et al., 2013). Among the "seismogenic" subduction zone, two distinct types are recognized. First, NE Japan and Costa Rica are characterized by a very small Neogene accretionary prism, a thin sedimentary cover on incoming plate composed mostly of pelagic or hemipelagic material and the subduction of most or all of the incoming sequence (Kimura et al., 1997; Morris and Villinger, 2006; Shipley and Moore, 1986; Von Huene and Lallemand, 1990; Von Huene et al., 1980; Von Huene et al., 2004). In contrast, Alaska and Nankai margins are characterized by a large Neogene accretionary prism, abundant terrigeneous influx of sediments to the trench, a thick sediment section at the trench, and the accretion of a variable proportion of it (Moore et al., 2009; Moore et al., 2005; Moore et al., 1991; von Huene et al., 1998). Among the aseismic subduction zone, Mariana, located far from any terrigeneous input, has only locally a very small accretionary prism and most or all of the $\sim 500 \mathrm{~m}$ thick sedimentary section, consisting principally in cherts and volcaniclastics, is subducted (Oakley et al., 2008; Shipboard Scientific Party, 1990). Barbados is characterized by a large accretionary prism, but the sedimentary sequence on top of the subducting plate at the drill site (DSDP Site 543) is relatively thin because it is located in the north of the 
margin, a zone poorer in sediments than in south (Westbrook et al., 1984). There, sediment section is $\sim 450 \mathrm{~m}$ thick and is composed of clays and mud (Shipboard Scientific Party, 1984).

In any case, we focused on the fraction of the sediment section bound to be subducted. Therefore, in Costa Rica (Shipboard Scientific Party, 1997), SW Japan (Shipboard Scientific Party, 2001a) and Barbados (Shipboard Scientific Party, 1984), we collected samples below the décollement or its seaward projection ("protodécollement"). For NE Japan (Shipboard Scientific Party, 1980) and Marianna (Shipboard Scientific Party, 1990) where the whole section is subducting, we analyzed the whole sedimentary column. For Alaska, at the trench the underthrusted section below the décollement has a thickness of $\sim 700 \mathrm{~m}$ (von Huene et al., 1998), which is also the thickness of the sedimentary sequence on top of the oceanic plate far from the trench at DSDP site 178 (Shipboard Scientific Party, 1973). As a simplifying assumption, we considered therefore that the whole section from Site 178 is equivalent to the subducting section. In all studied cores, regularly spaced samples were collected along the whole studied length, in order to get representative OM compositions of the sediment column to be subducted.

\section{2-Results}

\subsection{1-Types of $\mathrm{OM}$}


Two end-member subduction zones can be discriminated based on their TOC (Fig. 6) and HI/OI ratio (OI being the Oxygen Index) (Fig. 5 and Tab. 2): ocean-ocean subduction zones, such as Marianna, are characterized by a large contribution of marine OM (Type II), with large HI ( 300-700), hence large $\mathrm{H} / \mathrm{C}_{\text {atom }}(\sim 0.9-1.6)$, while ocean-continent subduction zones, such as Alaska, which receive a large supply of detrital material from the continent, including plant-derived type III OM, have a much lower HI ( 100), and hence a lower $\mathrm{H} / \mathrm{C}_{\text {atom }}$ ratio $(\sim 0.6)$. In parallel, ocean-ocean subduction zones are deprived of OM, with TOC mostly below $0.1 \%$ (Fig. 6), while ocean-continent subduction zones receive a larger supply of detrital OM, with TOC mostly in the range $0.1-1 \%$. In other words, the autochtonous, marine production of $\mathrm{OM}$ is very low $(\sim 0.1 \%)$ and subduction zone sediments characterized by larger TOC have incorporated the external supply of terrigenous OM.

\subsection{2-Methane productivity}

Methane productivity is at first order controlled by the total OM content (Fig. 6 and Tab.

2). Even if the OM of ocean-ocean subduction zones is richer in hydrogen than that of ocean-continent subduction zones (Fig. 5), such variations are subordinate to the amount of TOC, whose variations span over one order of magnitude from $0.1 \%$ in Marianna and up to $0.5-1 \%$ in many other subduction zones. As a result, the TOC can be 
used at first order as a proxy for methane productivity in subduction zones.

\section{6-Model of thermogenic methane production}

We only consider here the actual production of methane as a result of thermal cracking of $\mathrm{OM}$, in sediments on top of the subducting plate and below the décollement, which are undergoing burial and temperature increase. We do not take into account the biogenic production of methane, although it may be considerable in some instances, because an unknown fraction of this methane may leak from the yet uncompacted upper sediment column before entering subduction.

\subsection{Temperature/depth of cracking and associated porosity}

The conditions of cracking are at first order controlled by temperature. The type III organic matter that constitutes the largest component of the total OM stock in ocean-continent subduction zones (Fig. 5) reacts to form methane principally between 150 and $250^{\circ} \mathrm{C}$ (Fig. 7). Given the large variability of thermal régimes in subduction zones (Stevenson, 1993), we chose a depth of $10 \mathrm{~km}$ for the isotherm $150^{\circ} \mathrm{C}$ as lower bound. Indeed, this isotherm is crossed at $10 \pm 2 \mathrm{~km}$ in Nankai, a relatively "hot" type of subduction zone (Marcaillou et al., 2012), while it is crossed at $\sim 20 \mathrm{~km}$ depth along the plate interface in Tohoku-Oki (Kimura et al., 2012), and at $~ 30 \mathrm{~km}$ in Costa Rica (Harris et al., 2010). Similarly, the compilation of metamorphic conditions of oceanic or 
continental terranes subducted down to blueschist or eclogite-facies conditions show that the gradient is always lower than $15^{\circ} \mathrm{C} / \mathrm{km}$ (Agard and Vitale-Brovarone, 2013; Agard et al., 2009).

The porosity corresponding to such large depths is not well constrained. There is a wealth of data from core and log measurement from drilling in accretionary prisms, but they are mostly restricted to depths above $1 \mathrm{kmbsf}$, hence to large to moderate porosity (e.g. (Hyndman et al., 1993)). Data at larger depths are much more limited and come for example from shale basins, such as the Beaufort-Mackenzie Basin, Canada, where the porosity at $4 \mathrm{~km}$ depth drops down to $0-5 \%$ (Issler, 1992) or from the New Jersey coastal plain, where shale porosity become lower than $5 \%$ below $\sim 4 \mathrm{~km}$ depth (Kominz and Pekar, 2001). Similarly, compaction curves derived from the compilation of porosity-depth curves by Sclater and Christie (1980) show that in worldwide basin porosity is lower than $5 \%$ at 6-7 $\mathrm{km}$ depth. In addition, the additional tectonic loading in convergent margin results in even larger compaction (Bray and Karig, 1985). Furthermore, direct porosity measurements in the exhumed rocks of the Hyuga mélange are around 2.5\% (Tsuji et al., 2006). We therefore consider that the porosity of subducting sediments for depths $\sim 10 \mathrm{~km}$ is lower than $5 \%$, i.e. $\sim 50 \mathrm{~kg}$ of water per $\mathrm{m}^{3}$ of rock. 


\subsection{OM stock in incoming sediments}

Before being degraded by temperature, OM is firstly consumed by bacterial activity in the shallow sediment column. To estimate the stock of $\mathrm{OM}$ available for thermal cracking, it is necessary to subtract from the initial stock the fraction of OM consumed by bacterial activity.

To assess quantitatively how much of the initial $\mathrm{OM}$ stock is consumed by bacterial activity is very difficult (see Discussion 9.2). Considering the problem the other way round, one can try to evaluate the minimum depth a sediment volume has to reach before bacterial activity is sufficiently reduced so that $\mathrm{OM}$ concentration no longer varies.

For this purpose, only sediment sections with a constant supply in OM can be considered, which restricts strongly the possible sites. For example, in most sedimentary columns belonging to accretionary prisms, the increase in TOC towards the seafloor reflects to some extent the fact that the OM supply increases with the proportion of terrigenous sediment as the deposition site gets closer to the subduction front.

To avoid this problem, we considered a few sequences of typical deep sea sediment deposited at a constant distance from the continental source in time: this is the case of 
the Bering Sea (IODP 323, sites U1343 and U1344 ), Alaska margin (IODP 341, sites U1419 and U1420 (Expedition 341 Scientists, 2014)), and Mexican Gulf drill sites (IODP 308, site U1324 (Expedition 308 Scientists, 2006)). These hemipelagic sediments sections are all relatively rich in clay, contain $\mathrm{OM}$ principally in the range $0.5-2.5 \mathrm{wt} \%$ and span a large depth range in order to assess the TOC evolution within the sediment column as a result of bacterial activity (Fig. 9).

This compilation shows that the decrease in TOC, as a result of bacterial consumption, is concentrated in the first hundred meters of sediments. Deeper in the sediment (i.e. in most sediment cores analyzed in Tab. 2), if bacteria may be present, we consider that they do not significantly modify the stock of OM (this hypothesis is further discussed in 9.2). As a result, the $\mathrm{OM}$ stock in incoming sediments below $\sim 100 \mathrm{mbsf}$ can be considered as a good estimate of what reaches cracking depth and is transformed into methane.

\subsection{OM available for thermal cracking}

We consider a typical sediment of ocean-continent subduction zones, with a significant terrigenous input, hence prone to produce methane: in modern examples, TOC is often close to $0.5 \mathrm{wt} \%$ but can go up to $1 \mathrm{wt} \%$ (Fig. 6, SW and NE Japan, Costa Rica and Alaska), similarly to worldwide values compiled in (Larue, 1991).

This amount is estimated in core samples mostly below 100mbsf (Fig. 4), it corresponds 
therefore to the OM stock after most of the bacterial consumption has occurred. This stock is bound to be subducted with limited variation down to the much larger depths where thermogenic cracking occurs.

Similarly to these values in modern sediments, the fossil sediments of Hyuga contain up to $0.6 \mathrm{wt} \%$ of residual carbon, which converts according to Eq. 1 into $0.7 \mathrm{wt} \%$ of available TOC before thermal cracking (section 4.3).

\subsection{Types of models}

We consider in the following two different models. The first one is based on the hypothesis that the permeability field at cracking depths is so low that the system is closed in terms of fluid flux. It enables to derive analytically the maximum overpressure that can be produced in the subducting sediments. A second, 2D numerical model, consists in a parametric study of the actual overpressure as a function of the permeability field. It enables to determine the conditions on the permeability for significant overpressure to develop.

\section{7-Models of methane production - closed system}

The first, simplest model consists in considering that, at cracking depths, the permeability is too low for a significant flux of fluid (water and methane) to get out of the rock. If not realistic, it provides the order of magnitude of the overpressure that can 
be generated, as well as the physico-chemical state of the fluid wetting the rocks at these depths.

\subsection{Unmixing of methane}

Considering a typical sediment from continent-continent subduction zones, its methane production by OM thermal cracking ranges approximatively as $1-3 \mathrm{~kg}$ methane (60 to $190 \mathrm{~mol})$ per $\mathrm{m}^{3}$ of rocks (Figs 4 and 5).

As produced, methane is dissolved into the pore-filling water of sediments with a porosity lower than 5\%. Methane solubility in pure or seawater (Fig. 10, calculated from Duan and Mao (2006)) is only well constrained up to 200MPa, but as it is mostly dependent on temperature, one can extrapolate solubility to larger pressures/depths. At $250{ }^{\circ} \mathrm{C}$, methane solubility ranges up to $1.5 \mathrm{~mol} / \mathrm{kg}$ of water, hence the water contained in a pelitic sediment with $5 \%$ porosity can dissolve up to $75 \mathrm{~mol}$ of $\mathrm{CH}_{4} / \mathrm{m}^{3}$ of rock. The comparison between the storage capacity of dissolved methane $\left(75 \mathrm{~mol} / \mathrm{m}^{3}\right.$ of rock $)$ and the potential production (60 to $190 \mathrm{~mol} / \mathrm{m}^{3}$ of rock) shows that for standard incoming material and temperature conditions, cracking of OM in subduction zones produces a sufficient amount of methane to saturate the pore-filling water.

\subsection{Overpressures}

Let us consider again a typical sediment of ocean-continent subduction zones, with a 
significant terrigenous input, hence prone to produce methane: in modern examples, TOC is often close to $0.5 \mathrm{wt} \%$ but can go up to $1 \mathrm{wt} \%$ (Fig. 6), similarly to worldwide values compiled in (Larue, 1991). Similarly, the fossil sediments of Hyuga contain up to $0.6 \mathrm{wt} \%$ of residual carbon, which converts according to Eq. 1 into $0.7 \mathrm{wt} \%$ of initial (pre-cracking) TOC (section 4.3). In parallel, we consider $2.5-5 \%$ as the porosity range relevant for the depths where cracking occurs.

\subsubsection{Calculation procedure}

The calculation of fluid pressure variation associated with a chemical (thermal cracking of $\mathrm{OM}$ ) or physical (methane degassing of the aqueous fluid contained in the pores) process can be calculated according to the following scheme, which corresponds to a closed system evolution:

-Estimate $\delta \mathrm{V}_{0}$, the net production of volume associated with the process

-Calculate $\delta \mathrm{P}_{\mathrm{f}}$, the increase in fluid pressure, so that $\delta \mathrm{V}_{1}\left(\delta \mathrm{P}_{\mathrm{f}}\right)$, the variation in pore space associated with the pressure variation, obeys $\delta \mathrm{V}_{1}+\delta \mathrm{V}_{0}=0$, i.e. all the volume produced is accommodated within the rock volume.

The function $\delta \mathrm{V}_{1}\left(\delta \mathrm{P}_{\mathrm{f}}\right)$ is the sum of the volume variations of the bulk rock, the water in the pore and possibly the degassed methane if present. Its derivation is exposed in 7.2.1.1 and is used in 7.2.1.2 and 7.2.1.3 to estimate the fluid pressure variations 
associated with the cracking of $\mathrm{OM}$ and degassing of the pore fluid, respectively.

\subsubsection{1-Processes controlling the pressure variations in a rock with low porosity}

The accommodation of an extra volume within the pores of a given volume of rock results in an increase in fluid pressure, which can be calculated knowing the storage capacity of the pore fluid, the bulk rock and additional gas if present.

(1) Storage by compression of pore fluid

The storage capacity of the fluid contained in the pores (defined per $\mathrm{m}^{3}$ of rock) is a function of the volume of fluid and of its compressibility. Considering for the sake of simplicity pure water, at $200 \mathrm{MPa}$ and $200^{\circ} \mathrm{C}$, the isothermal compressibility of water is

(Wagner and Pruss, 2002):

$$
\frac{1}{\mathrm{~V}} \frac{\partial \mathrm{V}}{\partial P_{f}}=3.910^{-4} / \mathrm{MPa}
$$

If the rock porosity is $5 \%$, it contains $50 \mathrm{~L}$ of water per $\mathrm{m}^{3}$ of rock, hence the storage capacity $\alpha_{w}$ related to pore water compression is:

$$
\alpha_{w}=19.5 \mathrm{~cm}^{3} / \mathrm{MPa} / \mathrm{m}_{\text {rock }}^{3}
$$

If the rock porosity is $2.5 \%$, then storage capacity $\alpha_{w}$ is:

$$
\alpha_{w}=9.75 \mathrm{~cm}^{3} / \mathrm{MPa} / \mathrm{m}_{\text {rock }}^{3}
$$

(2) Storage by increase in pore space

The storage capacity of the rock corresponds to the excess pore volume it can create for a 
given increase in pore fluid pressure. For the sake of simplicity, we consider in what follows only isotropic rocks. In poroelasticity, the volumetric strain $\theta$ can be expressed as a function of confining pressure $P_{c}$ and fluid pressure $P_{f}$ (Nur and Byerlee, 1971):

$$
\theta=\frac{1}{K} P_{c}-\left(\frac{1}{K}-\frac{1}{K_{s}}\right) P_{f}
$$

where $K$ is the effective (=dry) bulk modulus of the rock and $K_{s}$ the modulus of the rock without pore (i.e. solid grains). As this strain is positive in compression, the storage capacity $\alpha_{\text {rock }}$ is simply defined as $\alpha_{\text {rock }}=-\frac{\delta \theta}{\delta P_{f}}=-\left(\frac{1}{K}-\frac{1}{K_{s}}\right)$.

Assessing $\alpha_{\text {rock }}$ implies to estimate $K$ and $K_{s}: K$ can be deduced from seismic velocities as $K=\rho\left(V_{p}^{2}-\frac{4}{3} V_{s}^{2}\right)$. In the Hyuga mélange rocks where methane-rich fluid inclusions were described, the velocities measured by (Tsuji et al., 2006) yield bulk modulus between 20 and $30 \mathrm{GPa}$, hence we take an average of $25 \mathrm{GPa}$. Note that it is a gross approximation, as the velocities differ depending on the direction with respect to foliation, hence the rock is not isotropic. Now, the solid grain elastic modulus $K_{S}$ incorporates all the grains constituting the rock, with varying lithology, size and morphology. Though its exact value is impossible to assess, an estimate can be found considering the bulk modulus of quartz, its major component: $K_{S}$ for quartz is of the order of 38 Gpa (Levien et al., 1980). Note that true $K_{S}$ should be slightly higher, as phyllosilicates present in the rock have a lower compressibility (for example $K_{s}$ for 
muscovite is of the order of $60 \mathrm{GPa}$ (Ortega-Castro et al., 2010)).

With these values, the volume increase of the rock can be estimated as

$$
\alpha_{\text {rock }} \approx \frac{1}{70} G P a^{-1}
$$

In other words, volume reduction for a pore fluid increase of $70 \mathrm{MPa}$ is $10^{-3}$, hence $1 \mathrm{~m}^{3}$ of rock reduces of $1000 \mathrm{~cm}^{3}$. Storage capacity is thus:

$$
\alpha_{\text {rock }} \approx 14 \mathrm{~cm}^{3} / \mathrm{MPa} / \mathrm{m}_{\text {rock }}^{3}
$$

(3) Storage by compression of gaseous methane

If methane is present, its compression adds additional storage capacity to the rock

(Duan et al., 1992), which depends on the amount of methane contained:

$$
\frac{\partial \overline{\mathrm{V}}_{\mathrm{CH}_{4}}}{\partial P_{f}} \approx-610^{-2} \mathrm{~cm}^{3} / \mathrm{mol} / \mathrm{MPa}
$$

For a TOC of $0.5 \%$, the OM considered produces $135 \mathrm{~mol}$ of $\mathrm{CH}_{4}$ per $\mathrm{m}^{3}$ of rock (see

calculations below), hence the storage capacity of the methane is:

$$
\alpha_{C H 4}=8.1 \mathrm{~cm}^{3} / \mathrm{MPa} / \mathrm{m}_{\text {rock }}^{3}
$$

The total storage capacity $\alpha_{\text {bulk }}$ of a rock is finally given by:

$$
\alpha_{\text {bulk }}=\alpha_{w}+\alpha_{\text {rock }}+\alpha_{C H 4}
$$

For a porosity of $5 \%$ and a TOC of $0.5 \%$ as well as for a porosity of $2.5 \%$ and a TOC of $1 \%$,

$$
\alpha_{\text {bulk }} \approx 40 \mathrm{~cm}^{3} / \mathrm{MPa} / \mathrm{m}_{\text {rock }}^{3}
$$




\subsubsection{2-Pressure variation during fluid degassing}

Let's consider a solution made of $1 \mathrm{~L}$ of water and dissolved $\mathrm{CH}_{4}$, where the concentration of $\mathrm{CH}_{4}$ exceeds the solubility limit by 1 mol per liter of water.

When degassing occurs, the increase in volume $\delta \mathrm{V}_{0}$ of the system at $\mathrm{P}$ and $\mathrm{T}$ constant is simply:

$$
\delta \mathrm{V}_{0}=\overline{\mathrm{V}}_{\mathrm{CH}_{4}}-\overline{\mathrm{V}}_{\mathrm{CH}_{4}}^{\mathrm{l}}
$$

where $\bar{V}_{\mathrm{CH}_{4}}$ is the molar volume of $\mathrm{CH}_{4}$ (in L/mol) as a free phase and $\overline{\mathrm{V}}_{\mathrm{CH}_{4}}$ is the partial molar volume of $\mathrm{CH}_{4}$ when dissolved in water. At 200MPa, i.e. at the upper limit of the model by (Duan and Mao, 2006), which uses the equations of state of Duan et al. (1992) for pure $\mathrm{CH}_{4}$ and Spivey et al. (2004) for $\mathrm{H}_{2} \mathrm{O}-\mathrm{NaCl}, 200^{\circ} \mathrm{C}$ and sea-water salinity,

$$
\delta \mathrm{V}_{0}=\overline{\mathrm{V}}_{\mathrm{CH}_{4}}-\overline{\mathrm{V}}_{\mathrm{CH}_{4}}^{\mathrm{l}} \approx 3 \mathrm{~cm}^{3} / \mathrm{mol}
$$

This implies that the mechanical mixture of $1 \mathrm{~L}$ of water and 1 mole of free $\mathrm{CH}_{4}$ phase has a larger volume than when this mole is dissolved into the water. The actual volume increase can in turn be estimated, knowing the amount (in moles) of $\mathrm{CH}_{4}$ produced by the breakdown of $\mathrm{OM}$ that exceeds the solubility limit, which is, in seawater at $200^{\circ} \mathrm{C}$ and $200 \mathrm{MPa}, 0.93 \mathrm{~mol} / \mathrm{kg}$ water.

Considering a sediment with a TOC of $0.5 \%$ and a porosity of $5 \%$, it produces $135 \mathrm{~mol}$ of 
methane (see below), of which 88 are in excess with respect to saturation. The associated net volume increase is $\delta \mathrm{V}=265 \mathrm{~cm}^{3} / \mathrm{m}_{\text {rock }}^{3}$. The corresponding fluid overpressure $\delta P_{f}$ is given by:

$$
\delta P_{f}=\frac{\delta \mathrm{V}}{\alpha_{b u l k}} \approx 6 \mathrm{MPa}
$$

For a TOC of $1 \%$ and a porosity of $2.5 \%$, a similar calculation gives:

$$
\delta P_{f} \approx 18 \mathrm{MPa}
$$

\subsubsection{3- Pressure variations associated with cracking of OM}

Let's consider the reaction of cracking of OM as:

$$
C_{x} H_{y} \rightarrow C_{x}+n C_{4}
$$

We seek the variation in volume (per unit mass) $\Delta \overline{\mathrm{V}}_{r}$ associated with this reaction.

As the precise nature of reacting $\mathrm{OM}$ is not known, we look for an upper bound on $\Delta \overline{\mathrm{V}}_{r}$ by considering a minimum density for the reactant: For example, vitrinite, a typical component of type III OM, has a minimum density of $1.28 \mathrm{~g} / \mathrm{cm}^{3}$ (massic volume 0.78 $\mathrm{cm}^{3} / g$ ) (Van Krevelen, 1961). For type III OM, considering relatively evolved material with a $\mathrm{HI}$ as low as $50 \mathrm{mg} \mathrm{HC} / \mathrm{gC}$.org (Tissot and Welte, 1978), density is $\sim 1.35 \mathrm{~g} / \mathrm{cm}^{3}$ (massic volume $0.74 \mathrm{~cm}^{3} / \mathrm{g}$ ) (Okiongbo et al., 2005). Pure carbon is considered as graphite, with a density at most $2.23 \mathrm{~g} / \mathrm{cm}^{3}$ (massic volume $0.45 \mathrm{~cm}^{3} / g$ ) (Roberts et al., 1990). Molar volume of methane is, at $200 \mathrm{MPa}$ and $200^{\circ} \mathrm{C}, \sim 0.34 \mathrm{~g} / \mathrm{cm}^{3}\left(2.94 \mathrm{~cm}^{3} / \mathrm{g}\right)$ 
(Duan et al., 1992).

Considering the typical reactant with a $\mathrm{HI}$ of $50 \mathrm{mg} \mathrm{HC} / \mathrm{gC}$.org, its atomic ratio $\mathrm{H} / \mathrm{C}$ is of the order of 0.5, hence $y=\frac{x}{2}$ (Espitalié et al., 1977).

For the sake of stoechiometry, the reaction of cracking can therefore be rewritten as

$$
C_{x} H_{\frac{x}{2}} \rightarrow C_{\frac{7 x}{8}}+\frac{x}{8} \mathrm{CH}_{4}
$$

Let's consider 1 mole of starting $\mathrm{OM}$, which produces $\mathrm{x} / 8 \mathrm{~mol}$ of $\mathrm{CH}_{4}$. The weight of starting material is $\left(\frac{25}{2} x\right) \mathrm{g}$, the weight of produced methane is $(2 x) \mathrm{g}$ and the pure carbon produced weighs $\left(\frac{21}{2} x\right)$ g.

Now let's consider $1 \mathrm{~g}$ of material is reacted, with a volume comprised between 0.74 and $0.78 \mathrm{~cm}^{3}$ : it produces $\frac{4}{25} \mathrm{~g}$ of $\mathrm{CH}_{4}$, with a volume of $0.47 \mathrm{~cm}^{3}$ and $\frac{21}{25} \mathrm{~g}$ of $\mathrm{C}$ with a volume of $0.38 \mathrm{~cm}^{3}$, hence a total volume of $0.85 \mathrm{~cm}^{3}$ for the reaction products. There is therefore a volume increase of $\sim 0.1 \mathrm{~cm}^{3} / \mathrm{g}$ of $\mathrm{OM}$.

Considering a sediment with a TOC of $0.5 \%$ and a porosity of $5 \%, 1 \mathrm{~m}^{3}$ of sediment has a weight of $2.710^{3} \mathrm{~kg}$ and contains $13500 \mathrm{~g}$ of OM. It produces, upon cracking, $2160 \mathrm{~g}$ (135 mol) of $\mathrm{CH}_{4}$, i.e. a volume of $\sim 6150 \mathrm{~cm}^{3}$.

From these 135 moles of methane produced, $46 \mathrm{~mol}$ are dissolved into water. The remaining methane $(89 \mathrm{~mol})$ has a volume of $4190 \mathrm{~cm}^{3}$ and corresponds to the total production of methane as a free phase (per $\mathrm{m}^{3}$ of rock). 
Now, considering the net volume production, i.e. the volume variation associated to the reaction, cracking $13500 \mathrm{~g}$ of OM results in a volume increase of $1350 \mathrm{~cm}^{3}$. In addition, the dissolution of a fraction (46 moles out of 135) of the produced methane into the pore-filling water results in an associated volume loss of $140 \mathrm{~cm}^{3}$. The net volume variation $\delta \mathrm{V}$, considering cracking $+\mathrm{CH}_{4}$ dissolution, is therefore $1210 \mathrm{~cm}^{3}$ per $\mathrm{m}^{3}$ of rock.

The associated fluid pressure variation can be calculated from the net volume variation.

$$
\delta P_{f}=\frac{\delta \mathrm{V}}{\alpha_{\text {bulk }}} \approx 29 \mathrm{MPa}
$$

If now the TOC is $1 \%$ and the porosity $2.5 \%$, the sediment produces $270 \mathrm{~mol}$ of $\mathrm{CH}_{4}$ and the net volume variation is $2630 \mathrm{~cm}^{3}$. The associated fluid pressure variation is:

$$
\delta P_{f}=\frac{\delta \mathrm{V}}{\alpha_{b u l k}} \approx 66 \mathrm{MPa}
$$

\subsection{2-Summary}

Under the closed system hypothesis, thermal cracking of OM to produce methane results in a pressure increase (see 7.2.1). The first source of overpressure is related to the exsolution of methane from the water in which it is dissolved: methane concentration within the pore water slowly increases along with thermal cracking, until reaching then exceeding solubility. Once overstepping is sufficient, rapid unmixing of the methane as a free phase (i.e. "bubbles" of supercritical methane in water) and drop 
in the concentration of dissolved methane back to solubility occur. This process is extremely rapid and results in overpressures, as the density of methane is larger as a dissolved species in water than as a free phase (see 7.2.1.2). Overpressure amplitude depends on the amount of methane dissolution in excess of solubility value, which is not well constrained. Considering as an upper bound that all the methane produced is first dissolved in the pore water before instantaneous unmixing, this overpressure can be as large as $\sim 18 \mathrm{MPa}$ (see 7.2.1.2). The second source of overpressure, simply related to the change in volume of the products compared to that of the reactants of Eq. 1, results in overpressures in the range $29-66 \mathrm{MPa}$ (see 7.2 .1 .3 ). As it results from progressive burial/T increase, the typical time scale for the pressure buildup associated with thermal cracking is the million years.

\section{8-Models of methane production - drained system}

A more realistic estimate of the fluid pressure buildup in subducting sediments requires to consider, in addition to fluid sources as a result of cracking, fluid pressure dissipation as a result of flow out of the rocks. Two main paths of outflow are considered: (a) upward flow within the hanging wall and (b) lateral flow with the décollement and its associated damage zone. A first model (model 1) considers only path (a), while model 2 considers the combination $(a+b)$. In each case, we estimate upper bounds on permeability values 
for significant overpressure to develop.

\section{1-Model setup}

\subsubsection{Geometry and physical parameters}

The subducting sediments have a thickness of $\sim 90 \mathrm{~m}$ (Fig. 8), comprising an upper horizon, of thickness of $\sim 30 \mathrm{~m}$, accommodating all the strain between upper and lower plate. The subduction dip angle is $10^{\circ}$, the thermal gradient along the plate interface is $\sim 15^{\circ} \mathrm{C} / \mathrm{km}$. The subducting sediments enter the modelled box at a depth of $10 \mathrm{~km}$ and exit it at a depth of $13 \mathrm{~km}$, so that they pass through the $150-200^{\circ} \mathrm{C}$ temperature range, where we consider that most OM is cracked and methane is produced. The horizontal size of the box is $17 \mathrm{~km}$. The subduction velocity is $5 \mathrm{~cm} / \mathrm{yr}$. The dynamic viscosity of the fluid is calculated at $300 \mathrm{MPa}$ and $150^{\circ} \mathrm{C}$ as $2.510^{-4} \mathrm{~Pa} . \mathrm{s}$ (Wagner and Pruss, 2002). Modelling has been performed with with the Comsol Multiphysics ${ }^{\mathrm{TM}}$ software (finite element method).

\subsubsection{Fluid source}

Considering a sediment with a TOC of $0.5 \%$ and a porosity of $5 \%, 1 \mathrm{~m}^{3}$ of sediment, produces upon OM thermal cracking and methane generation a net pore volume of $1210 \mathrm{~cm}^{3}$ (see 7.2.1.3). The net production of pore volume over the whole control domain per year is equal to the difference between the material entering the control domain 
$\left(V_{\text {in }}\right)$ and the material leaving it, hence $1210 \mathrm{~cm}^{3} \mathrm{x} V_{\text {in. }} . V_{\text {in }}$ (per year and per meter parallel to the margin) is $90 \mathrm{~m} \times 5 \mathrm{~cm} \times 1 \mathrm{~m}=4.5 \mathrm{~m}^{3}$, the pore volume production per year is $\sim 510^{-3} \mathrm{~m}^{3}$. The whole control volume is $100 \mathrm{~m} \times 17000 \mathrm{~m} \times 1 \mathrm{~m}$. The resulting volume production, in other words the source term in porous flow equation, is therefore $\sim 10^{-16}$ $\mathrm{m}^{3} / \mathrm{m}^{3}$ of rock $/ \mathrm{s}$.

\subsubsection{Permeability field}

The dissipation of overpressure produced in the control volume of subducting sediments results from the flow out of fluid following two main paths: (1) a vertical flow through the upper plate domain and (2) a lateral flow through the décollement zone, which could constitute a more permeable horizon. To account for these two distinct contributions, we run two kinds of models. In the first class of models, the décollement zone has the same permeability as the upper plate, hence all fluid outflow is vertical through the upper plate. In the second class of models, we fixed an increased permeability to the décollement zone to allow the lateral outflow.

The permeability in the clay-rich subducting sediments varies in the range $10^{-20}$ to $10^{-22} \mathrm{~m}^{2}$, i.e. very low values, corresponding to the low-porosity, clay-rich nature of the rocks (Neuzil, 1994; Saffer and Bekins, 2006). This value plays a minor role in the pressure dissipation, as the sediment layer is really thin and cannot, whatever its 
permeability, efficiently retain the overpressure (see 8.2.1).

The permeability in the upper plate varies over the range $10^{-18}$ to $10^{-22} \mathrm{~m}^{2}$. In the second class of model, the permeability of the décollement varies in the range $10^{-14}$ to $10^{-21} \mathrm{~m}^{2}$.

\subsubsection{Initial and boundary conditions}

In the initial conditions, the pore fluid pressure is everywhere hydrostatic. It increases with time as a result of the source of fluid. The lateral boundaries are impermeable to the flow in the first class of models, as the problem is principally unidimensional in the vertical direction. In the second class of model, the lateral boundaries are also impermeable, but for the right boundary of the décollement zone, where hydrostatic pressure conditions are prescribed to allow the flow out through the décollement zone.

\section{2-Results}

We consider in the following pore pressure profiles when the system has reached a steady state, i.e. when fluid outflow is equivalent to fluid source. Fluid overpressure $(\Delta \mathrm{P})$ is defined as the difference between actual $\left(\mathrm{P}_{\mathrm{f}}\right)$ and hydrostatic fluid pressure $\left(\mathrm{P}_{f \_h y d}\right)$.

8.2.1 Models with no flow through the décollement

In this model, all the flux is vertical and the overpressure iso-lines are horizontal. The maximum overpressure is located in the deepest points of the model (Fig. 11) and its 
amplitude varies with the permeability of the upper plate (Fig. 12). The development of large, i.e. $>10 \mathrm{MPa}$, overpressure in the subducting sediments and above, requires permeability in the upper plate lower than $\sim 210^{-21} \mathrm{~m}^{2}$.

8.2.2 Models with significant flow through the décollement

Considering conditions where the upper plate has a sufficiently low permeability to enable overpressure build-up, the drainage through the décollement zone is efficient only when its permeability is higher than $\sim 10^{-18} \mathrm{~m}^{2}$ (Fig. 13 and 14), while lower permeability results in significant overpressure development in the subducting sediments.

\section{9-Discussion}

\section{1-Methane as a free phase in subduction fluids}

Our analysis of OM evolution and methane thermogenic production during burial shows that methane unmixing from aqueous pore waters is not a rare phenomenon but can be expected for most subduction zone sediments, which receive a significant terrigenous input. Indeed, similarly to the example provided by the Hyuga mélange rocks, which contain an amount of OM typical of modern subduction zones (see 4.3), occurrences of methane-rich fluid inclusions are reported from worldwide fossil subduction zones, including the Shimanto Belt (Sakaguchi, 1999), Kodiak in Alaska (Vrolijk et al., 1988) or 
the Franciscan Complex (Dalla Torre et al., 1996). The typical deep fluids from accretionary prisms can therefore be described chemically as a mixture of salt water and methane and physically as a two-phase mixture, one being water-rich and the other one being methane-rich. The stability domain of $\mathrm{CH}_{4}$-rich fluids is limited to temperatures of $\sim 300^{\circ} \mathrm{C}$ and the Central Alps show a clear transition with increasing grade of $\mathrm{H}_{2} \mathrm{O}+\mathrm{CH}_{4}$ mixtures into $\mathrm{H}_{2} \mathrm{O}+\mathrm{CO}_{2}$ ones (Mullis et al., 1994).

The trapping of $\mathrm{CH}_{4}$-rich fluid in inclusions in Hyuga quartz veins occurred during the rock retrograde evolution, hence not directly on the plate interface. But as these rocks followed a nearly isothermal retrograde evolution, their OM was completely refractory at the time they were wetted by the methane-rich fluids. We interpreted therefore these fluids as percolating from the plate interface (Raimbourg et al., 2014b), where OM thermal cracking and methane production are concentrated. Earthquakes along the plate interface and associated damaging provide therefore a plausible process to account for the instantaneous pressure drop recorded in fluid inclusions (Fig. 2).

\section{2-Budget of hydrocarbons in subducted sediments}

The generation of overpressure as a result of OM thermal cracking within subducted sediments is controlled by the flux in, i.e. the OM content of the sediments reaching the conditions of OM thermal cracking, and the flux out, i.e. the leakage of hydrocarbons as 
they are produced.

9.2.1 Flux in: organic matter in subducting sediments

To estimate the influx of organic matter entering subduction, we assumed that bacterial

OM degradation was mostly efficient in the upper few hundred(s) meters of sediment, so that the average TOC value in the deeper part of drill sites $(0.5 \mathrm{wt} \%)$ is representative of the remaining OM available for thermal cracking (Fig. 6 and Tab. 2). Although this value is clearly in the lower range of worldwide TOC concentrations compiled by Larue (1991), it is important to discuss the validity of this assumption given its importance in the model. With increasing depth, bacterial proliferation (and OM consumption) becomes limited by the availability of electron acceptors, itself controlled by their rate of downward diffusion from seawater. The assumption of limited bacterial OM consumption below a certain thickness of sediments is supported by the observed distribution of bacteria with depth, showing in general a strong decrease in bacteria concentration beyond a few tens of meters of sediments (Parkes et al., 2000). Of course, there are counterexamples, in particular in deformed sediments where fluid advection may supply nutriments to greater overburden depths. This is the case in the Nankai accretionary prism, where certain sites show large and uniform concentrations in bacteria over the entire cored section (e.g. the $\sim 500 \mathrm{~m}$-longcores in Sites C0004 
(Expedition 316 Scientists, 2009a) or C0007 (Expedition 316 Scientists, 2009b)). The majority of drill sites show that these counterexamples, however, are exceptions to the rule, and that metabolic activity vanishes within few 100s meters under the sea floor. This is the case in the west African margin showing a sharp peak in methanogenesis at $\sim 100 \mathrm{mbsf}$, then a drop toward negligible values below 200mbsf (Sivan et al., 2007). In Nankai Trough Site 1175 (D'Hondt et al., 2002), the sulfate, methane and bacteria concentration profiles with depth shows that the associated metabolic activity is mostly confined to the first 100m of sediments (Shipboard Scientific Party, 2001c). In deep ocean sediments from the Woodlark Basin, direct measurements of methanogenesis rates have been carried out under experimental conditions, and show a tenfold decrease in methanogenesis rates over the first 200mbsf (Wellsbury et al., 2002). At IODP site C0009, in the fore-arc basin of the Nankai Trough area where gas hydrates are present (Moore et al., 2009), the amount of in situ methane produced by the bacteria and contained in the sediments section richest in methane $(1050-1250 \mathrm{mbsf})$ is $10-20 \mathrm{~L}_{\mathrm{CH} 4} / \mathrm{L}_{\text {sediment, }}$, hence a mass proportion of $\sim 0.5 \mathrm{wt} \%$ (Wiersberg et al., 2015). In the same interval, the TOC ranges between 2.5 and $5 \mathrm{wt} \%$, five to ten times larger than our preferred value, suggesting that the OM influx considered in our model is indeed conservative. In this perspective of keeping our model conservative, it is also important 
to recall that we neglected the influx of biogenic methane in the subduction because of its possible leakage, although it may considerably increase the total methane budget and fluid overpressure.

9.2.2 Flux out: hydrocarbons vented out of subducting sediments along with thermal cracking

The schematic evolution of subducting sediments, in terms of hydrological properties, is closely correlated to its porosity and permeability decrease along with burial (Neuzil, 1994): From a high-porosity, high-permeability open system near ocean floor, it evolves towards a low-porosity, low-permeability closed system at depth. Indeed, significant fluid expulsion in the shallow part of accretionary prism is evidenced for example by heat flow data or cold seeps and mud diapirs (Henry et al., 1992; Henry et al., 1996; Kastner et al., 1991; Shipley et al., 1990). In addition to this shallow source of fluid produced principally by sediment compaction and reduction of pore spaces (Le Pichon et al., 1993), geochemical analyses of pore fluid in drilled cores point in many instances to the additional contribution of a deeper source of fluid, evidenced by the fluid low salinity (Gieskes et al., 1990; Kastner et al., 1991; Saffer and Tobin, 2011), This "deep" fluid, focused along the décollement, carries hydrocarbons formed by thermogenic cracking of organic matter, as shown by the $\delta^{13} \mathrm{C}$ of dissolved methane in Barbados (Vrolijk et al., 
1990) or by the presence of propane in costa Rica (Morris and Villinger, 2006). Therefore, the sediment is still leaking at the depths of organic matter thermogenic cracking $\left(\sim 150-200^{\circ} \mathrm{C}\right.$, see Fig. 7$)$, even though the porosity and permeability are reduced.

Quantifying such leakage is difficult, because most of the gases dissolved in the pore fluid are lost upon core recovery. In Costa Rica, where propane was identified within the décollement, gas sampling technique does not allow for an estimate of the gas content with respect to a given fluid or rock volume (Haeckel, 2006), hence does not allow quantifying the hydrocarbon flux out of the OM thermal cracking zone.

An indirect analysis of the fluid and gas flux within subducting sediments during burial is provided by the geochemistry of cold springs through serpentine mud volcanoes in the Mariana Trench (Mottl et al., 2004). The systematic geochemical trend with distance from the trench shows that the fluid mixing along the subducting interface is limited, for $\mathrm{T}$ condition of the order of $150^{\circ} \mathrm{C}$. Similarly, in metapelites from the Shimanto Belt, the Franciscan Complex or Kodiak, oxygen and carbon isotopic features of the veins formed in the $\mathrm{T}$ range $150-350^{\circ} \mathrm{C}$ point to local buffering by host-rock (Brantley et al., 1998; Lewis and Byrne, 2003; Raimbourg et al., 2015; Sadofsky and Bebout, 2001). This set of observations suggest that percolation of fluids, which would homogenize the geochemical signatures of the subducting sediments, is much restricted. It supports a 
model where the leakage of fluid and hydrocarbons from the depth of OM thermal cracking to the surface is limited. Therefore, if such leakage is undisputably attested by ODP/IODP measurements of the chemistry of pore fluid in cores from shallow depth, it is probably not sufficient to release most of the overpressure generated by $\mathrm{OM}$ thermal cracking at depth.

\section{3- Fluid pressure distribution}

\subsubsection{Permeability field}

The numerical modelling developed in section 8 provides estimates of maximum permeability required for the significant overpressure to develop, that are $\sim 210^{-21} \mathrm{~m}^{2}$ for the upper plate (Fig. 12) and $\sim 10^{-18} \mathrm{~m}^{2}$ for the décollement zone (Fig. 14), both conditions to be fulfilled simultaneously.

\subsubsection{Upper plate permeability}

In modern and fossil accretionary prism, the nature of the upper plate nature is variable, for example igneous rocks in Costa Rica (Vannucchi et al., 2001) or sediments in Shimanto Belt (Raimbourg et al., submitted), which might influence its permeability. In the Costa Rica example, the "reference" hydrological model by Spinelli et al. (2006) includes an upper plate with a permeability of $\sim 10^{-20} \mathrm{~m}^{2}$, but a larger range of permeability $\left(10^{-18.5} \mathrm{~m}^{2}\right.$ to $\left.10^{-21} \mathrm{~m}^{2}\right)$, including the values calculated here as necessary to 
permit overpressure, actually fits the model constraints.

For sedimentary/metasedimentary upper plate, Saffer and Bekins (2006) consider in their generic model that permeability is controlled by the porosity and the nature of the material. Based on the compilation of Neuzil (1994) for clay-rich material, the linear $\log$ (permeability)-porosity relationships of Saffer and Bekins (2006) predict, for clay fraction in the range $10-100 \%$ and porosity below $5 \%$, a permeability in the range $10^{-22}-$ 3. $10^{-21} \mathrm{~m}^{2}$. Such a very low permeability in argillaceous rocks is further supported by permeability experiments on illite-bearing shales (Kwon et al., 2004) or on a large range of mudstones (Yang and Aplin, 2007, 2010). In contrast, sandstone-rich material have a permeability that is higher, by several orders of magnitude, than clay-rich rocks (Nelson, 1994).

As a consequence, in sedimentary and metasedimentary wedges, the condition for upper plate permeability to be as low as $\sim 10^{-21} \mathrm{~m}^{2}$ at large scale is that (i) mudstone-rich units are abundant (ii) the more permeable, sandstone rich units do not form a connected network from $10 \mathrm{~km}$ depth to the surface.

\subsubsection{Décollement zone permeability}

The other condition for overpressure to develop as a result of OM thermal cracking is a relatively low permeability décollement, at most $\sim 10^{-18} \mathrm{~m}^{2}$. 
These low values are relatively counter-intuitive with respect to the classical picture of the tip of accretionary wedge, where the décollement zone is considered as a drain focusing the flow out of the accretionary prism (Saffer and Tobin, 2011), with permeability in the range $10^{-14}$ to $10^{-17} \mathrm{~m}^{2}$ (Henry and Le Pichon, 1991; Saffer and Bekins, 1998; Spinelli et al., 2006). These values are constrained partly by modelling solute concentration profiles (Saffer and Bekins, 1998; Spinelli et al., 2006) or by direct permeability measurements (Bekins et al., 2011), both at low depth $(<1 \mathrm{kmbsf})$, so that they are relevant for the relatively shallow portion ( a few $\mathrm{kms}$ depth) of the accretionary prism.

The evolution of décollement permeability at larger depth $(\mathrm{z}>10 \mathrm{~km})$ is difficult to determine, but estimates can be proposed, based on its structure and lithology.

The décollement structure, in its very shallow termination, has been described in ocean drilling campaigns. For example, in the Japan Trench, a 1m-thick scaly clay is defined as the main slip zone, surrounded by a $\sim 10 \mathrm{~m}$-thick zone of increased deformation (dark seams and bands) (Chester et al., 2013). In Nankai (Shipboard Scientific Party, 2001a) and in Barbados (Maltman et al., 1997), the décollement zone is 30-40m thick, with brecciated horizons and in Barbados, localized horizons showing scaly clay and S-C fabrics. In any example, the décollement zone is a horizon with a thickness of at least 
$10 \mathrm{~m}$ where fracturing and brecciation concentrate, with a relatively heterogeneous internal structure in terms of deformation intensity.

Further away from the trench, direct sampling is impossible and one has to rely on the examples provided by tectonic mélanges within fossil structures on-land. In particular, the Mugi mélange within the Shimanto Belt is interpreted as a tectonic unit deformed along the plate interface during subduction, for temperature conditions of the order of the ones considered for OM thermal cracking (Kitamura et al., 2005). Internal deformation is highly heterogeneous, with meter-scale fault zones cutting across domains of tectonic mélange affected by a penetrative network of smaller-scale faults and shear zones (Kitamura and Kimura, 2012). Paleodécollement zone at depth are therefore similar to the shallow fault structure, with large-scale faults embedded in a penetratively and finely deformed domain that can be interpreted as the "damage" zone. The permeability of the deformed zone is much different in the core and in the damage zone. Fault cores, where material is comminuted to a very small grain size, has a permeability that is relatively small, of the order of $10^{-18} \mathrm{~m}^{2}$ parallel to the fault zone to $10^{-21} \mathrm{~m}^{2}$ perpendicular to it (Faulkner and Rutter, 2003; Morrow et al., 1984). The permeability of the damage zone is possibly much higher, as a result of the network of fractures formed (Faulkner et al., 2010). Experiments show an increase up to 2-3 orders 
of magnitude with respect to unfractured, initial material (Mitchell and Faulkner, 2008;

Uehara and Shimamoto, 2004), while measurements in natural faults also show several orders of magnitude increase between fault core and damage zone (Wibberley, 2002). But these consideration are derived from faults in coarse-grained crystalline rocks and it is not clear to which extent they apply to very fine-grained, clay-rich metasedimentary rocks of low grade. Fracturing experiments in low-porosity shales sampled near the Chelungpu fault did not result in a significant increase in permeability, which remained close to its initial low value of $\sim 10^{-19} \mathrm{~m}^{2}$ (Chen et al., 2009). Similarly, faults in deep (up to $4 \mathrm{~km}$ depth), clay-rich samples from the North Sea and the Norwegian Shelf are made of phyllosilicates (clay smears), with a very low permeability $\left(\sim 10^{-20} \mathrm{~m}^{2}\right)$. Furthermore, the fracture permeability in shale is highly dependent on the effective pressure, with a decrease by 2-3 orders of magnitude for Peff in the range $0-40 \mathrm{MPa}$ (Chen et al., 2009). The fracture permeability of the damage zone in very fine-grained, clay-rich metasediments forming the décollement zone at $\mathrm{OM}$ thermal cracking depth, such as the Mugi mélange (Kitamura and Kimura, 2012), can in these conditions be as low as $\sim 10^{-18} \mathrm{~m}^{2}$, in which case overpressure development in subducting sediments and at the base of the upper plate, is possible.

9.3.2 Sources of fluid at $\mathrm{T}>150^{\circ} \mathrm{C}$ : $\mathrm{OM}$ thermal cracking vs. smectite-to-illite reaction 
Overpressures in subducting sediments are reported in a large depth range (Saffer and Tobin, 2011) and below a few $\mathrm{km}$ depth they mostly depend on dehydration reactions. For sediments, the most significant dewatering reactions involve silica phase and clays. The opal-to-quartz transformation is completed at $\sim 100^{\circ} \mathrm{C}$ (Spinelli et al., 2007), while the smectite-to-illite reaction proceeds principally in the range $50^{\circ}-150^{\circ} \mathrm{C}$ (Pytte and Reynolds, 1989). Therefore, deeper than the isotherm $150^{\circ} \mathrm{C}$ and down to $\sim 300^{\circ} \mathrm{C}$, fluid sources include the last increments of the smectite-to-illite reaction and the thermal cracking of OM.

Estimating the former fluid source requires to assess the temperature dependence of the smectite-to-illite reaction. The analysis of reaction progress in natural sedimentary basins show that above $\sim 150^{\circ} \mathrm{C}$ the smectite content in interstraified I/S is only $10-20 \%$ at most (Huang et al., 1993; Pollastro, 1993; Pytte and Reynolds, 1989; Velde and Vasseur, 1992).

The smectite proportion in subducting sediments and décollement zone is highly variable from negligible to above $90 \%$ (Vrolijk, 1990). In their model of smectite-to-illite reaction in the Nankai subduction zone, Saffer et al. (2008) considered a proportion of $45 \%$ of smectite in whole rock.

The volumetric proportion of water in smectite depends on pressure and temperature, 
with relationships that are not well constrained (Ransom and Helgeson, 1994a; Vidal and Dubacq, 2009). We assume as an upper bound that it contains a volumetric proportion of $\sim 20 \%$ of water (Saffer et al., 2008; Spinelli and Saffer, 2004), corresponding to two layers of water in interlayer space.

The resulting volume of water bound to smectite above $\sim 150^{\circ} \mathrm{C}$ is $\sim 1-2 \%$ in volume of total rock, for sedimentary rocks with a large $(\sim 50 \%)$ proportion of smectite. This compares to, or is slightly larger, than the average volume of methane generated by OM thermal cracking, of the order of $0,6 \%$ of rock volume $\left(\sim 6150 \mathrm{~cm}^{3} / \mathrm{m}^{3}\right.$ of rock, see 7.2 .1 .3$)$. This estimate of the total stored fluid (either water or methane) disregards how the release rate of fluid varies with temperature: OM thermal cracking and methane production peaks around $180^{\circ} \mathrm{C}$ for rapid burial (Fig. 7), while water released by smectite-to-illite reaction constantly decreases with $\mathrm{T}$, in the range above $150^{\circ} \mathrm{C}$ (Saffer and Tobin, 2011). The generation of fluid by OM thermal cracking may therefore become the major source of fluid for temperatures above $180-200^{\circ} \mathrm{C}$. Smectite-to-illite reaction is unfortunately too complex a reaction for available kinetic models (Huang et al., 1993; Pytte and Reynolds, 1989; Velde and Vasseur, 1992) to faithfully reproduce the "tail" of the reaction, i.e. the domain where smectite fraction become very small.

Furthermore, following the approach by Neuzil (1995), the generation of overpressure 
from the diagenetic transformations requires considering not the fluid production, but rather the total volume variation resulting from the reaction. This quantity, which we called net volume production, is the one we used in our numerical model of overpressure generation (section 8). It is only a fraction of total fluid produced, as the production of fluid is compensated by a decrease in the volume of the solid phases. In the case of OM thermal cracking, the net volume production is only $1 / 5$ of the total fluid production $\left(\sim 1200 \mathrm{~cm}^{3} / \mathrm{m}^{3}\right.$ of rock vs. $\sim 6150 \mathrm{~cm}^{3} / \mathrm{m}^{3}$ of rock, see 7.2 .1 .3$)$. The same considerations apply to smectite-to-illite reaction, which requires to know the difference in water density between interlayer and bulk state.

At high $\mathrm{P}$ and $\mathrm{T}$, interlayer water volumetric mass is extremely poorly constrained (Colten-Bradley, 1987). Even at ambient $\mathrm{P}$ and $\mathrm{T}$, it is only indirectly estimated as $17.22 \mathrm{~cm}^{3} / \mathrm{mol}$ (Ransom and Helgeson, 1994b), to be compared to $18.07 \mathrm{~cm}^{3} / \mathrm{mol}$ for bulk water (Wagner and Pruss, 2002). Although the calculation is not done for the relevant $\mathrm{P}$ and $\mathrm{T}$ conditions, for water, the net volume variation between interlayer and bulk state is only $1 / 20$ of the water volume. In other words, the net volume increase resulting from smectite dehydration is only $1 / 20$ of the water released.

Because of this difference in net volume production (1/5 for OM thermal cracking vs. 1/20 for smectite dehydration, with respect to total fluid produced), OM thermal 
cracking appears, above $150^{\circ} \mathrm{C}$, as the principal source of overpressure, if not of fluid.

\subsubsection{Dissipation vs. sources of fluid pressure}

The fluid pressure field results from the dynamic equilibrium between sources of pressure and outflow of fluid (Neuzil, 1995). This dynamic equilibrium is integrated into an adimensional ratio $\Gamma L / \kappa$, where $\Gamma$ is the geological forcing, i.e. the source term (in $\mathrm{m}^{3}$ of fluid $/ \mathrm{m}^{3}$ of rock/s), $\kappa$ the hydraulic conductivity (in $\mathrm{m} / \mathrm{s}$ ) and $L$ the drainage length (in $\mathrm{m}$ ). As detailed above, the source term corresponds to the net volume production associated with diagenetic reactions, which is only a fraction of the total fluid production.

Cases where $\Gamma L / \kappa>1$ correspond in principle to overpressure development and this prediction was validated in hydraulic models of accretionary prisms (Saffer and Tobin, 2011). In our simpler model of vertical outflow, without décollement, $\Gamma / \kappa L>1$ corresponds to permeability of the upper plate lower than $\sim 310^{-20} \mathrm{~m}^{2}$. Such a threshold on permeability coincides rather well with the onset of the overpressure (Fig. 12).

\section{4-Implications of overpressure for seismogenesis}

In the models where the décollement and upper plate permeability is low, the amplitude of the overpressures associated with OM thermal cracking is significant, as it compares with the overall deviatoric state of stress, estimated as $\sim 5-15 \mathrm{MPa}$ from earthquakes 
where stress drop was total (Hasegawa et al., 2012), 35MPa from analog experiments (Duarte et al., 2015), or 7-37MPa from global force balance (Lamb, 2006). Therefore, in subducting sediments where continuous burial and load increase result in an average high level of pore fluid pressure, the additional overpressure related to deep methane generation may have a mechanical effect and enhance slip.

The temperature range of OM thermal cracking is particularly relevant for earthquake generation, as the $150^{\circ} \mathrm{C}$ isotherm defines the updip limit of the seismogenic zone in the classical model by Hyndman et al. (1997). Adding more recent earthquakes and thermal models for subduction zones further supports Hyndman et al. (1997)'s model: most plate interface rupture initiates in the $\mathrm{T}$ range $150-300^{\circ} \mathrm{C}$ (Fig. 15). Temperature characteristics with the T-range of OM thermal cracking and methane production for Type III OM (gray box in Fig. 15) coincide therefore with earthquake nucleation. This possible link between OM thermal cracking and seismogenesis is further supported by the correlation between distribution of earthquake and methanogenesis potential: The ocean־ocean subduction zones considered here are barren in $\mathrm{OM}$ and are aseismic (Heuret et al., 2011), while the ocean-continent subduction zones, which contain a significant amount of OM, are associated with large earthquakes.

The potential mechanism connecting OM thermal cracking and seismogenesis is twofold. 
First, subducting sediments concentrate OM-cracking-related methane production as they are the constant source of "fresh" OM to be cracked at depth. Consequently, the associated overpressure affect their upper boundary, i.e. the seismic plate interface. The maximum amplitude of methane-related overpressure in modern sediments (up to $66 \mathrm{MPa}$, see 7.2 .1 .3 ) or in Hyuga mélange rocks (up to $50 \mathrm{MPa}$, for a porosity of $2.5 \%$ (Tsuji et al., 2006)) is of the order of earthquake-related pressure variations recorded by fluid inclusions (Fig. 2). Second, unmixing of methane from an aqueous fluid, which can occur as a result of deformation during seismic slip, generates an additional pore pressure increase. Such instantaneous pressure increase is a weakening process promoting further slip.

These coupled effects (slow increase in fluid overpressure with burial, instantaneous fluid pressure increase during slip) suggest that methane production from OM may favor earthquake generation in subduction zones. To further test this hypothesis would require a much higher density of core data in worldwide margins, as the spatial distribution of $\mathrm{OM}$ is extremely heterogeneous. A good example of this heterogeneity is given by NE Japan margin, where the 2011 Tohoku-Oki slip zone was drilled in Site C0019 (Expedition 343/343T Scientists, 2013). There, the décollement runs extremely close to the oceanic crust, so subducted sediment column is extremely thin and 
comprises only pelagic clays and cherts with a low TOC. On the other hand, seismic profiles across the subduction zone show that the subducting crust is cut regularly by normal faults making horsts and grabens and a sediment cover much thicker than at site C0019 is subducted in the hanging wall of normal faults (Chester et al., 2013). These sediments contain potentially a larger TOC (as they sample wedge sediments, richer in OM, similarly to site 436 in Fig. 6) and can be the source of thermogenic methane at depth. Because of these variations, it is difficult to make precise estimates of the subducted OM stock. In addition, earthquake generation is a very complex process where multiple factors probably intervene, including for example the topography of the subducting plate (Perfettini et al., 2010) or the lithological content of subducting material (Cloos and Shreve, 1996). Notwithstanding this complexity and heterogeneity, the difference in subducted OM may play a major role in the simplistic dichotomy between "Mariana-type" and "Chilean-type" subduction zones (Uyeda and Kanamori, 1979).

\section{Conclusion}

Source rocks from subduction zones have a low total organic content, hence a low potential in hydrocarbon generation by industrial standards (Bordenave et al., 1993). Nonetheless, because of the relatively low thermal gradient prevailing in such zones, 
hydrocarbon generation occurs at large depths, where pore fluid volume is small and rock permeability low (Neuzil, 1995). The consequences of these conditions for OM thermal cracking are twofold. First, the concentration of methane generated is sufficient to saturate the pore-filling water, so that the fluid at depths larger than $10 \mathrm{~km}$ is two-phased, i.e. made of a mechanical mixture of water-rich and methane-rich fluids. Second, our models show that OM thermal cracking is a potential source of fluid overpressure. The temperature range for OM thermal cracking, as well as the comparison in OM budget between seismic and aseismic subduction zones, suggest that cracking-related overpressure may facilitate seismogenesis. 


\section{Acknowledgements}

This work has received funding from (i) the European Research Council (ERC) under the seventh Framework Programme of the European Union (ERC Advanced Grant, grant agreement No 290864, RHEOLITH) and (ii) the Labex VOLTAIRE (ANR-10-LABX-100-01). We thank Laurent Guillou-Frottier for his help with the numerical modelling. 


\section{Figures}

Figure 1: A) Sample site of quartz veins containing the studied fluid inclusions in the Hyuga mélange unit from the Shimanto Belt, on Kyushu Island, Japan. B) Photomicrographs of secondary methane-rich fluid inclusions. The three pictures, taken by slightly changing the focus of the microscope, highlight the fluid inclusion distribution along a plane at low angle with the surface of the thin section, corresponding to a healed microfracture. B') Close-up view of a characteristic fluid inclusion, in the center of photomicrograph in B). The inclusion has a regular shape and is filled by a single, methane-rich phase.

Figure 2: A) Temperatures of methane homogenization of methane-rich fluid inclusions.

Each plot corresponds to inclusions along a single plane. B) Trapping pressure of the fluid, inferred as the intersection of the isochore of its host inclusion with the $\mathrm{T} \sim 250^{\circ} \mathrm{C}$ isotherm. The large scatter in homogenization temperatures of the inclusions in a given plane reflects the large variations in fluid pressure over the short time necessary for the microfracture plane to heal. For example, a $\Delta T$ of $\sim 10^{\circ} \mathrm{C}$ in homogenization temperatures converts into a pressure variation $\triangle P \sim 50 M P a$. 
Figure 3: Distribution of core samples analyzed in Fig. 6, 7 and Tab. 2. The underlying map, showing the plate boundary nature, is adapted from Von Huene and Scholl (1991).

Figure 4: Lithostratigraphic column of all core samples analyzed with Rock-Eval (Figs.

5, 6 and Tab. 2).

Figure 5: Rock-Eval analyses of ODP/DSPS/IODP sediment samples shown in a pseudo

Van-Krevelen diagram, with the three generic types of OM.

Figure 6: Potential methane productivity as a function of their TOC for sediments in worldwide subduction zones. Methane productivity is derived from TOC and HI parameters given by Rock-Eval analysis of sediments core samples (see 4.2.2). Blue/black symbols refer to ocean-ocean/ocean-continent subduction zones, respectively.

Figure 7: Cracking of OM resulting from the increase in temperature, calculated using the software Temis Suite 2008 from the Beicip Franlab and a TOC of $0.5 \%$ wt. We considered two kinds of OM, representative of marine ("Landana") and terrigenous ("Brent") kerogene, and rapid $\left(300^{\circ} \mathrm{C}\right.$ in $\left.1.5 \mathrm{Ma}\right)$ or slow $\left(300^{\circ} \mathrm{C}\right.$ in $\left.15 \mathrm{Ma}\right)$ burial-increase 
in T. For terrigeneous material, irrespectively of burial rate, cracking occurs principally in the $\mathrm{T}$ range $150-250^{\circ} \mathrm{C}$.

Figure 8: Model of thermogenic cracking of OM. (A) The domain modelled numerically in section 8 is shown as the grey area. It comprises a thin section of subducting sediments at its bottom and the overlying upper plate. (B) Close-up view of the subducting sediments at the bottom of the modelled domain. It is composed of $60 \mathrm{~m}$ of undeformed material below a $\sim 30 \mathrm{~m}$-thick décollement zone accommodating all the deformation. The $90 \mathrm{~m}$-thick section (=control volume) is affected by thermal cracking of OM. The upper limit of the control volume is at a depth of $\sim 10 \mathrm{~km}$, corresponding to the isotherm $150^{\circ} \mathrm{C}$ for a gradient of $15^{\circ} \mathrm{C} / \mathrm{km}$. The overpressure within the control volume and above is the result of the balance between gas production and gas leakage (through the décollement and the upper plate).

Figure 9: TOC as function of depth in several deep sea sediment columns. Drilling sites are located at a fixed position with respect to the source of OM, so that the supply of OM can be considered as constant with time of deposition/depth in the column. The associated lithostratigraphic columns are described in Supplemental File. 
Figure 10: Curves of iso-solubility in $\mathrm{mol} / \mathrm{kg}$ of methane in pure water (dashed lines) and seawater (solid lines), calculated from Duan and Mao (2006).

Figure 11: Field of overpressure $\left(\Delta \mathrm{P}=\mathrm{P}_{\mathrm{f}}-\mathrm{P}_{\mathrm{f} \_ \text {hyd }}\right)$ for the case where permeability is set at $10^{-21} \mathrm{~m}^{2}$ for the upper plate and at $10^{-22} \mathrm{~m}^{2}$ for the subducting sediment. The maximum overpressure, $\sim 22 \mathrm{MPa}$, is located in the lower left corner of the model.

Figure 12: Maximum overpressure $\Delta \mathrm{P}$ as a function of subducting sediment and upper plate permeability. Overpressure amplitude is controlled by upper plate permeability. Significant, i.e. $>10 \mathrm{MPa}$, overpressure occur only when the permeability of the upper plate is lower than $\sim 210^{-21} \mathrm{~m}^{2}$. The criterion $\Gamma L / \kappa=1$ is defined in Neuzil (1995) as the threshold for overpressure to develop (see 9.3.3).

Figure 13: Field of overpressure $\left(\Delta \mathrm{P}=\mathrm{P}_{\mathrm{f}}-\mathrm{P}_{\mathrm{f}_{-} \text {hyd }}\right)$ for the case where permeability is set at $10^{-17} \mathrm{~m}^{2}(\mathrm{~A})$ and $10^{-19} \mathrm{~m}^{2}(\mathrm{~B})$ for the décollement zone and at $5.10^{-22} \mathrm{~m}^{2}$ for the upper plate. In the case (A) where the décollement has a relatively high permeability, it enables an efficient drainage of the subducting sediments and prevents large overpressure to 
develop. The case of a low permeability décollement zone (B) is similar to the models where the outflow is vertical.

Figure 14: Maximum overpressure $\Delta \mathrm{P}$ as a function of décollement and upper plate permeability. Décollement with a permeability larger than $\sim 10^{-18} \mathrm{~m}^{2}$ efficiently drains the fluid out of subducting sediments and dissipates overpressure, while décollement permeability lower than $\sim 10^{-18} \mathrm{~m}^{2}$ results in significant overpressure build-up.

Figure 15: Comparison of the subduction zone mega-earthquakes temperatures characteristics with the T-range of OM thermal cracking and methane production for Type III OM (gray box). Temperature of the slip maximum/nucleation for mega-earthquakes were determined using relocalized hypocenters/slip zones and thermal models according to: Japan NE 2011 - (Lay et al., 2011; Suzuki et al., 2012; Wada and Wang, 2009), Sumatra 2004 - (Engdahl et al., 2007; Rhie et al., 2007; Syracuse et al., 2010; Wada and Wang, 2009), Chile 1960 and 2010 - (Vigny et al., 2011; Völker et al., 2011), Nankai 1944 - (Marcaillou et al., 2012), other south american earthquakes and Alaska 1964 - (Oleskevich et al., 1999). For Sumatra 2004, the T of the zone of maximum coseismic slip is lower than $125^{\circ} \mathrm{C}$, while for Nankai 1944 , the maximum coseismic slip 
is defined as $>1 \mathrm{~m}$. For Maule earthquake (Chile 2010), two patches of maximum slip were identified (Vigny et al., 2011).

Table 1: Summary of Rock-Eval analyses of Hyuga mélange rocks. Note that due to the very low amount of pyrolysed hydrocarbons $\mathrm{S} 2$, the value of Tmax is extremely ill-defined. Samples on the coast appear with a yellow color. PC, RC and TOC stand for pyrolysed, residual carbon and total organic content, respectively.

Table 2: Summary of Rock-Eval analyses of worldwide subduction zone sediments. 


\section{References}

Agard, P., Vitale-Brovarone, A., 2013. Thermal regime of continental subduction: The record from exhumed HP-LT terranes (New Caledonia, Oman, Corsica). Tectonophysics 601, 206-215.

Agard, P., Yamato, P., Jolivet, L., Burov, E., 2009. Exhumation of oceanic blueschists and eclogites in subduction zones: Timing and mechanisms. Earth Sci. Rev. 92, 53-79.

Audet, P., Schwartz, S.Y., 2013. Hydrologic control of forearc strength and seismicity in the Costa Rican subduction zone. Nature Geoscience 6, 852-855.

Bakker, R.J., 2009. Package FLUIDS. Part 3: Correlations between equations of state, thermodynamics and fluid inclusions. Geofluids 9, 63-74.

Barker, C., 1990. Calculated volume and pressure changes during the thermal cracking of oil to gas in reservoirs. AAPG Bull. 74, 1254-1261.

Bekins, B.A., Matmon, D., Screaton, E.J., Brown, K.M., 2011. Reanalysis of in situ permeability measurements in the Barbados décollement. Geofluids 11, 57-70.

Bordenave, M.L., 1993. Applied petroleum geochemistry. Technip Editions, Paris.

Bordenave, M.L., Espitalié, J., Leplat, P., Oudin, J.L., Vandenbroucke, M., 1993. Screening techniques for source rock evaluation, in: Bordenave, M.L. (Ed.), Applied petroleum geochemistry. Technip Editions, Paris, pp. 217-278. 
Brantley, S.L., Fisher, D.M., Deines, P., Clark, M.B., Myers, G., 1998. Segregation veins: evidence for the deformation and dewatering of a low-grade metapelite, in: Holness, M.B. (Ed.), Deformation-enhanced fluid tranport in the Earth's crust and mantle. Chapman and Hall, London, pp. 267-288.

Bray, C.J., Karig, D.E., 1985. Porosity of sediments in accretionary prisms and some implications for dewatering processes. J. Geophys. Res. 90, 768-778.

Chen, T.-M., Zhu, W., Wong, T.-F., Song, S.-R., 2009. Laboratory characterization of permeability and its anisotropy of Chelungpu fault rocks. Pure and Applied Geophysics 166, 1011-1036.

Chester, F.M., Rowe, C., Ujiie, K., Kirkpatrick, J., Regalla, C., Remitti, F., Moore, J.C., Toy, V., Wolfson-Schwehr, M., Bose, S., Kameda, J., Mori, J.J., Brodsky, E.E., Eguchi, N., Toczko, S., Scientists, E.a.T., 2013. Structure and composition of the plate-boundary slip zone for the 2011 Tohoku-Oki earthquake. Science 342, 1208-1211.

Cloos, M., Shreve, R., 1996. Shear zone thickness and the seismicity of chilean- and mariana-type subduction zones. Geology 24, 107-110.

Cobbold, P.R., Mourgues, R., Boyd, K., 2004. Mechanism of thin-skinned detachment in the Amazon Fan: assessing the importance of fluid overpressure and hydrocarbon generation. Mar. Petrol. Geol. 21, 1013-1025. 
Colten-Bradley, V.A., 1987. Role of pressure in smectite dehydration - Effects on geopressure and smectite-to-illite transformation. AAPG Bull. 71, 1414-1427.

D'Hondt, S.L., Rutherford, S., Spivack, A.J., 2002. Metabolic activity of subsurface life in deep-sea sediments. Science 295, 2067-2070.

Dalla Torre, M., De Capitani, C., Frey, M., Underwood, M., Mullis, J., Cox, R., 1996. Very low-temperature metamorphism of shales from the Diablo Range, Franciscan Complex, California: New constraints on the exhumation path. GSA Bull. 108, 578-601.

Duan, Z., Mao, S., 2006. A thermodynamic model for calculating methane solubility, density and gas phase composition of methane-bearing aqueous fluids from 273 to $523 \mathrm{~K}$ and 1 to 2000 bars. Geochim. Cosmochim. Ac. 70, 3369-3386.

Duan, Z., Moller, N., Weare, J.H., 1992. An equation of state for the $\mathrm{CH}_{4}-\mathrm{CO}_{2}-\mathrm{H}_{2} \mathrm{O}$ system: I. Pure systems from 0 to $1000^{\circ} \mathrm{C}$ and 0 to 8000 bar. Geochim. Cosmochim. Ac. 56, 2605-2617.

Duarte, J.C., Schellart, W.P., Cruden, A.R., 2015. How weak is the subduction zone interface. Geophys. Res. Lett. 42, 1-10.

Engdahl, E.R., Villasenor, A., DeShon, H.R., Thurber, C.H., 2007. Teleseismic relocation and assessment of seismicity (1918-2005) in the region of the 2004 Mw 9.0 Sumatra-Andaman and 2005 Mw 8.6 Nias Island great earthquakes. Bull. Seism. Soc. Am. 97, S43-S61. 
Espitalié, J., Laporte, J.L., Madec, M., Marquis, F., Leplat, P., Paulet, J., Boutefeu, A., 1977.

Méthode rapide de caractérisation des roches mères, de leur potentiel pétrolier et de leur degré d'évolution. Revue de l'IFP 32, 23-42.

Expedition 308 Scientists, 2006. Site U1324, in: Flemings, P.B., Behrmann, J.H., John, C.M.

(Eds.), Proc. IODP, vol. 308.

Expedition 316 Scientists, 2009a. Expedition 316 Site C0004, in: Kinoshita, M., Tobin, H.,

Ashi, J., Kimura, G., Lallemant, S., Screaton, E.J., Curewitz, D., Masago, H., Moe, K.T., Expedition 314/315/316 Scientists (Eds.), Proc. IODP, 314/315/316. Integrated Ocean Drilling Program Management International, Inc., Washington, DC, pp. 1-107.

Expedition 316 Scientists, 2009b. Expedition 316 Site C0007, in: Kinoshita, M., Tobin, H.,

Ashi, J., Kimura, G., Lallemant, S., Screaton, E.J., Curewitz, D., Masago, H., Moe, K.T., Expedition 314/315/316 Scientists (Eds.), Proc. IODP, 314/315/316. Integrated Ocean Drilling Program Management International, Inc., Washington, DC, pp. 1-110. doi:110.2204/iodp.proc.314315316.314315135.314312009.

Expedition 341 Scientists, 2014. Southern Alaska Margin: interactions of tectonics, climate, and sedimentation. IODP Prel. Rept. 341, 192.

Expedition 343/343T Scientists, 2013. Site C0019, in: Chester, F.M., Mori, J., Eguchi, N., Toczko, S. (Eds.), Proc. IODP, Vol. 343/343T. 
Faulkner, D.R., Jackson, C.A.L., Lunn, R.J., Schlische, R.W., Shipton, Z.K., Wibberley, C., Withjack, M.O., 2010. A review of recent developments concerning the structure, mechanics and fluid flow properties of fault zones. J. Struct. Geol. 32, 1557-1575.

Faulkner, D.R., Rutter, E.H., 2003. The effect of temperature, the nature of the pore fluid, and subyield differential stress on the permeability of phyllosilicate-rich fault gouge. J. Geophys. Res. 108, 1-12.

Gieskes, J.M., Blanc, G., Vrolijk, P., Elderfield, H., Barnes, R., 1990. Interstitial water chemistry-Major constituents, in: Moore, J.C., Mascle, A., et al. (Eds.), Proc. ODP, Sci. Res., vol 110, pp. 155-178.

Haeckel, M., 2006. A transport-reaction model of the hydrological systems of the Costa Rica subduction zone, in: Morris, J.D., Villinger, H.W., Klaus, A. (Eds.), Proc. ODP, Sci. Results, 205, pp. 1-26.

Harris, R.N., Spinelli, G., Ranero, C.R., Grevemeyer, I., Villinger, H.W., Barckhausen, U., 2010. Thermal regime of the Costa Rican convergent margin: 2. Thermal models of the shallow Middle America subduction zone offshore Costa Rica. Geochemistry Geophysics Geosystems 11, 1-22.

Hasegawa, A., Yoshida, K., Asano, Y., Okada, T., Iinuma, T., Ito, Y., 2012. Change in stress field after the 2011 great Tohoku-Oki earthquake. Earth Planet. Sci. Lett. 355-356, 231-243. 
Henry, P., Foucher, J.-P., Le Pichon, X., Sibuet, M., Kobayashi, K., Tarits, P., Chamot-Rooke, N., Furuta, T., Schultheiss, P., 1992. Interpretation of temperature measurements from the

Kaiko-Nankai cruise: Modeling of fluid flow in clam colonies. Earth Planet. Sci. Lett. 109, 355-371.

Henry, P., Le Pichon, X., 1991. Fluid flow along a decollement layer: A model applied to the $16^{\circ} \mathrm{N}$ section of the Barbados accretionary wedge. J. Geophys. Res. 96, 6507-6528.

Henry, P., Le Pichon, X., Lallemant, S., Lance, C., et al., 1996. Fluid flow in and around a mud volcano field seaward of the Barbados accretionary wedge: Results from Manon cruise. J. Geophys. Res. 101, 20,297-220,323.

Heuret, A., Lallemand, S., Funiciello, F., Piromallo, C., Faccenna, C., 2011. Physical characteristics of subduction interface type seismogenic zones revisited. G-cubed 12, 1-26.

Huang, W.-L., Longo, J.M., Pevear, D.R., 1993. An experimentally derived kinetic model for smectite-to-illite conversion and its use as a geothermometer. Clays Clay Miner. 41, 162-177.

Hyndman, R.D., Moore, G.F., Moran, K., 1993. Velocity, porosity, and pore-fluid loss from the Nankai subduction zone accretionary prism, in: Hill, I.A., Taira, A., Firth, J.V. (Eds.), Proc. ODP, Sci. Results, Vol. 131, pp. 211-220. doi:210.2973/odp.proc.sr.2131.2125.1993.

Hyndman, R.D., Yamano, M., Oleskevich, D.A., 1997. The seismogenic zone of subduction thrust faults. The Island Arc 6, 244-260. 
Issler, D.R., 1992. A new approach to shale compaction and stratigraphic restoration,

Beaufort-Mackenzie Basin and Mackenzie Corridor, Northern Canada. AAPG Bull. 76, 1170-1189.

Kameda, J., Yamaguchi, A., Saito, S., Sakuma, H., Kawamura, K., Kimura, G., 2011. A new source of water in seismogenic subduction zones. Geophys. Res. Lett. 38, 1-5.

Kastner, M., Elderfield, H., Martin, J.B., 1991. Fluids in convergent margins: What do we know about their composition, origin, role in diagenesis and importance for oceanic chemical fluxes? Phil. Trans. R. Soc. Lond. 335, 243-259.

Kato, A., Iidaka, T., Ikuta, R., Yoshida, Y., et al., 2010. Variations of fluid pressure within the subducting oceanic crust and slow earthquakes. Geophys. Res. Lett. 37, 1-5.

Kimura, G., Hina, S., Hamada, Y., Kameda, J., Tsuji, T., Kinoshita, M., Yamaguchi, A., 2012. Runaway slip to the trench due torupture of highly pressurized megathrust beneath the middle trench slope: The tsunamigenesis of the 2011Tohoku earthquake off the east coast of northern Japan. Earth Planet. Sci. Lett. 339-340, 32-45.

Kimura, G., Silver, E.A., Blum, P., et al., 1997. Proc. ODP, Init. Repts. College Station, TX (Ocean Drilling Program) 170.

Kitamura, Y., Kimura, G., 2012. Dynamic role of tectonic mélange during interseismic process of plate boundary mega earthquakes. Tectonophysics 568-569, 39-52. 
Kitamura, Y., Sato, K., Ikesawa, E., Ikehara-Ohmori, K., Kimura, G., Kondo, H., Ujiie, K., Onishi, C.T., Kawabata, K., Hashimoto, Y., Mukoyoshi, H., Masago, H., 2005. Melange and its seismogenic roof decollement: A plate boundary fault rock in the subduction zone - An example from the Shimanto Belt, Japan. Tectonics 24.

Kodaira, S., Takahashi, N., Nakanishi, A., Miura, S., Kaneda, Y., 2000. Subducted seamount imaged in the rupture zone of the 1946 Nankaido earthquake. Science 289, 104-106.

Kominz, M.A., Pekar, S.F., 2001. Oligocene eustasy from two-dimensional sequence stratigraphic backstripping. GSA Bull. 113, 291-304.

Kondo, H., Kimura, G., Masago, H., Ohmori-Ikehara, K., Kitamura, Y., Ikesawa, E., Sakaguchi, A., Yamaguchi, A., Okamoto, S., 2005. Deformation and fluid flow of a major out-of-sequence thrust located at seismogenic depth in an accretionary complex: Nobeoka Thrust in the Shimanto Belt, Kyushu, Japan. Tectonics 24.

Kwon, O., Kronenberg, A.K., Gangi, A.F., Johnson, B., Herbert, B.E., 2004. Permeability of illite-bearing shale: 1 . Anisotropy and effects of clay content and loading. J. Geophys. Res. $109,1-19$.

Lamb, S., 2006. Shear stresses on megathrusts : Implications for mountain building behind subduction zones. J. Geophys. Res. 111, doi:10.1029/2005JB003916.

Larue, K.D., 1991. Organic matter in the Franciscan and Cedros subduction complexes: the 
problems of "instantaneous maturation" and "missing petroleum" in accretionary prisms

Mar. Petrol. Geol. 8, 468-482.

Lay, T., Ammon, C.J., Kanamori, H., Xue, L., Kim, M.J., 2011. Possible near-trench slip during the $2011 \mathrm{Mw} 9.0$ off the Pacific coast of Tohoku Earthquake. Earth Planets Space 63.

Le Pichon, X., Henry, P., Lallemant, S., 1993. Accretion and erosion in subduction zones: The role of fluids. Annu. Rev. Earth Pl. Sc. 21, 307-331.

Levien, L., Prewitt, C.T., Weidner, D.J., 1980. Structure and elastic properties of quartz at pressure. Am. Mineral. 65, 920-930.

Lewis, J.C., Byrne, T.B., 2003. History of metamorphic fluids along outcrop-scale faults in a

Paleogene accretionary prism, SW Japan: Implications for prism-scale hydrology. G-cubed 4, $1-10$.

Maltman, A., Labaume, P., Housen, B., 1997. Structural geology of the decollement at the toe of the Barbados accretionary prism, in: Shipley, T.H., Ogawa, Y., Blum, P., Bahr, J.M. (Eds.), Proc. ODP, Sci. Results, 156, pp. 279-292.

Marcaillou, B., Henry, P., Kinoshita, M., et al., 2012. Seismogenic zone temperatures and heat-flow anomalies in the To-nankai margin segment based on temperature data from IODP expedition 333 and thermal model. Earth Planet. Sci. Lett. 349-350, 171-185.

Maubeuge, F., Lerche, I., 1994. Geopressure evolution and hydrocarbon generation in a north 
Indonesian basin: two-dimensional quantitative modelling. Mar. Petrol. Geol. 11.

Michael, K., Bachu, S., 2001. Fluids and pressure distributions in the foreland-basin succession in the west-central part of the Alberta basin, Canada: Evidence for permeability barriers and hydrocarbon generation and migration. AAPG Bull. 85, 1231-1252.

Mitchell, T.M., Faulkner, D.R., 2008. Experimental measurements of permeability evolution during triaxial compression of initially intact crystalline rocks and implications for fluid flow in fault zones. J. Geophys. Res. 113, 1-16.

Moore, G., Park, J.O., Bangs, N.L., Gulick, S.P., Tobin, H.J., Nakamura, Y., Saito, S., Tsuji, T., Yoro, T., Tanaka, H., Uraki, S., Kido, Y., Sanada, Y., Kuramoto, S., Taira, A., 2009. Structural and seismic stratigraphic framework of the NanTroSEIZE Stage 1 transect, in: Kinoshita, M., Tobin, H., Ashi, J., Kimura, G., Lallemant, S., Screaton, E.J., Curewitz, D., Masago, H., Moe, K.T., Expedition 314/315/316 Scientists (Eds.), Proc. IODP, 314/315/316. Integrated Ocean Drilling Program Management International, Inc., Washington, DC, pp. 1-46. doi:10.2204/iodp.proc.314315316.314315102.314312009.

Moore, G.F., Mikada, H., Moore, J.C., Becker, K., Taira, A., 2005. Legs 190 and 196 synthesis: Deformation and fluid flow processes in the Nankai Trough accretionary prism, in: Mikada, H., Moore, G.F., Taira, A., Becker, K., Moore, J.C., Klaus, A. (Eds.), Proc. ODP, Sci. Results, 190/196, pp. 1-26. doi:10.2973/odp.proc.sr.190196.190201.192005. 
Moore, J.C., Diebold, J., Fisher, M.A., Sample, J., Brocher, T., Talwani, M., et al., 1991.

EDGE deep seismic reflection transect of the eastern Aleutian arc-trench layered lower crust reveals underplating and continental growth. Geology 19, 420-424.

Moore, J.C., Vrolijk, P., 1992. Fluids in accretionary prisms. Rev. Geophys. 30, 113-135.

Moreno, M., Haberland, C., Oncken, O., Rietbrock, A., Angiboust, S., Heidbach, O., 2014.

Locking of the Chile subduction zone controlled by fluid pressure before the 2010 earthquake.

Nature Geoscience 7, 292-296.

Morris, J.D., Villinger, H.W., 2006. Leg 205 synthesis: subduction fluxes and fluid flow across the Costa Rica convergent margin, in: Morris, J.D., Villinger, H.W., Klaus, A. (Eds.), Proc. ODP, Sci. Rpts, vol. 205, p. doi:10.2973/odp.proc.sr.2205.2006.

Morrow, C.A., Shi, L.Q., Byerlee, J.D., 1984. Permeability of fault gouge under confining pressure and shear stress. J. Geophys. Res. 89, 3193-3200.

Mottl, M., Wheat, C.G., Fryer, P., Gharib, J., 2004. Chemistry of springs across the Mariana forearc shows progressive devolatilization of the subducting plate. Geochim. Cosmochim. Ac. $68,4915-4933$.

Mukoyoshi, H., Hirono, T., Hara, H., Sekine, K., Tsuchiya, N., Sakaguchi, A., Soh, W., 2009. Style of fluid flow and deformation in and around an ancient out-of-sequence thrust: An example from the Nobeoka Tectonic Line ine the Shimanto accretionary complex, southwest 
Japan. Island Arc 18.

Mullis, J., Dubessy, J., Poty, B., O'Neil, J., 1994. Fluid regimes during late stages of a continental collision: Physical, chemical, and stable isotope measurements of fluid inclusions in fissure quartz from a geotraverse in the Central Alps, Switzerland. Geochim. Cosmochim. Ac. $58,2239-2267$.

Nelson, P.H., 1994. Permeability-porosity relationships in sedimentary rocks. Log. Anal. $38-62$.

Neuzil, C.E., 1994. How permeable are clays and shales? Water Resour. Res. 30, 145-150.

Neuzil, C.E., 1995. Abnormal pressures as hydrodynamic phenomena. Am. J. Sci. 295, $742-786$

Nur, A., Byerlee, J.D., 1971. An exact effective stress law for elastic deformation of rock with fluids. J. Geophys. Res. 76.

Oakley, A.J., Taylor, B., Moore, G.F., 2008. Pacific Plate subduction beneath the central Mariana and Izu-Bonin fore arcs: New insights from an old margin. G-cubed 9, 1-28.

Okamoto, S., Kimura, G., Takizawa, S., Yamaguchi, H., 2006. Earthquake fault rock indicating a coupled lubrication mechanism. e-Earth 1, 23-26.

Okiongbo, K.S., Aplin, A.C., Larter, S.R., 2005. Changes in Type II kerogen density as a function of maturity: Evidence from the Kimmeridge Clay Formation. Energy \& Fuels 19, 
2495-2499.

Oleskevich, D.A., Hyndman, R.D., Wang, K., 1999. The updip and downdip limits to great subduction earthquakes: Thermal and structural models of Cascadia, south Alaska, SW Japan, and Chile. J. Geoph. Res. 104, 14965-14991.

Ortega-Castro, J., Hernández-Haro, N., Timón, V., Sainz-Díaz, C.I., Hernández-Laguna, A., 2010. High-pressure behavior of 2M1 muscovite. Am. Mineral. 95.

Osborne, M.J., Swarbrick, R.E., 1997. Mechanisms for generating overpressure in sedimentary basins: a reevaluation. AAPG Bull. 81, 1023-1041.

Palazzin, G., Raimbourg, H., Famin, V., Jolivet, L., Kusaba, Y., Yamaguchi, A., 2016.

Deformation processes at the down-dip limit of the seismogenic zone: The example of Shimanto accretionary complex. Tectonophysics $687,28-43$.

Parkes, J.R., Cragg, B.A., Wellsbury, P., 2000. Recent studies on bacterial populations and processes in subseafloor sediments: a review. Hydrogeology J. 8, 11-28.

Perfettini, H., Avouac, J.-P., Tavera, H., Kositsky, A., Nocquet, J.-M., Bondoux, F., Chlieh, M., Sladen, A., Audin, L., Farber, D.L., Soler, P., 2010. Seismic and aseismic slip on the Central Peru megathrust. Nature 465.

Pollastro, R.M., 1993. Considerations and applications of the illite/smectite geothermometer in hydrocarbon-bearing rocks of Miocene to Mississippian age. Clays Clay Miner. 41, 
119-133.

Pytte, A.M., Reynolds, R.C., 1989. The thermal transformation of smectite to illite, in: Naeser, N.D., McCulloh, T.H. (Eds.), Thermal history of sedimentary Basins: Methods and case histories. Springer-Verlag, New York, pp. 33-40.

Raimbourg, H., Augier, R., Famin, V., Gadenne, L., Palazzin, G., Yamaguchi, A., Kimura, G., 2014a. Long-term evolution of an accretionary prism: the case study of the Shimanto Belt, Kyushu, Japan. Tectonics 33, 1-24.

Raimbourg, H., Famin, V., Palazzin, G., Sakaguchi, A., Yamaguchi, A., Augier, R., submitted. Tertiary evolution of the Shimanto Belt (Japan): a large-scale collision in Early Miocene. Tectonics.

Raimbourg, H., Thiery, R., Vacelet, M., Ramboz, C., Cluzel, N., Trong, E.L., Yamaguchi, A., Kimura, G., 2014b. A new method of reconstituting the P-T conditions of fluid circulation in an accretionary prism (Shimanto, Japan) from microthermometry of methane-bearing aqueous inclusions. Geochim Cosmochim Ac 125, 96-109.

Raimbourg, H., Vacelet, M., Ramboz, C., Famin, V., Augier, R., Palazzin, G., Yamaguchi, A., Kimura, G., 2015. Fluid circulation in the depths of accretionary prisms: an example of the Shimanto Belt, Kyushu, Japan. Tectonophysics 655, 161-176.

Ransom, B., Helgeson, H., 1994a. A chemical and thermodynamic model of dioctahedral 2: I 
layer clay minerals in diagenetic processes: Dehydration of dioctahedral aluminous smectite as a function of temperature and depth in sedimentary basin. 1. 295, 245-228.

Ransom, B., Helgeson, H., 1994b. Estimation of standard molal heat capacities, entropies and volumes of 2:1 clay minerals. Geochimica et Cosmochimica Acta 58, 4537-4547.

Rhie, J., Dreger, D., Bürgmann, R., Romanowicz, B., 2007. Slip of the 2004 Sumatra-Andaman earthquake from joint inversion of long-period global seismic waveforms and GPS static offsets. Bull. Seism. Soc. Am. 97, S115-S127.

Roberts, Z.L., Campbell, T.J., Rapp, G.R.J., 1990. Encyclopedia of minerals (2nd edition). Van Nostrand Reinhold, New York.

Sadofsky, S.J., Bebout, G.E., 2001. Paleohydrology at $5^{-}$to 50-kilometer depths of accretionary prisms: The Franciscan Complex, California. Geophys. Res. Lett. 28, 2309-2312.

Saffer, D., McKiernan, A.W., 2009. Evaluation of in situ smectite dehydration as a pore water freshening mechanism in the Nankai Trough, offshore southwest Japan. Geochem. Geophys. Geosystems 10, 1-24.

Saffer, D., Tobin, H.J., 2011. Hydrogeology and mechanics of subduction zone forearcs: Fluid flow and pore pressure. Ann. Rev. Earth Planet. Sci. 39, 157-186.

Saffer, D., Underwood, M., McKiernan, A.W., 2008. Evaluation of factors controlling smectite transformation and fluid production in subduction zones: Application to the Nankai Trough. 
Island Arc 17.

Saffer, D.M., Bekins, B.A., 1998. Episodic fluid flow in the Nankai accretionary complex:

Timescale, geochemistry, flow rates and fluid budget. J. Geophys. Res. 103, 30,351-330,370.

Saffer, D.M., Bekins, B.A., 2006. An evaluation of factors influencing pore pressure in accretionary complexes: Implications for taper angle and wedge mechanics. J. Geophys. Res. 111, doi:10.1029/2005JB003990.

Sakaguchi, A., 1999. Thermal maturity in the Shimanto accretionary prism, southwest Japan, with the thermal change of the subducting slab: Fluid inclusion and vitrinite reflectance study. Earth Planet. Sci. Lett. 173, 61-74.

Sclater, J.G., Christie, P.A.F., 1980. Continental stretching: An explanation of the post-mid-Cretaceous subsidence of the Central North Sea Basin. J. Geophys. Res. 85, 3711-3739.

Screaton, E.J., Saffer, D.M., Henry, P., Hunze, S., Leg 190 Shipboard Party, 2002. Porosity loss within the underthrust sediments of the Nankai accretionary complex: Implications for overpressures. Geology 30, 19-22.

Shipboard Scientific Party, 1973. Site 178, in: Musich, L., Weser, O.E. (Eds.), Proc. DSDP, Init. Rpts, vol. 18, p. doi:10.2973/dsdp.proc.2918.2109.1973.

Shipboard Scientific Party, 1980. Site 436: Japan Trench outer rise, Leg 56, in: Lee, M., Stout, 
L.N. (Eds.), DSDP, Init. Rpts, vol. 56-57, p. ddoi:10.2973/dsdp.proc.5657.2107.1980.

Shipboard Scientific Party, 1984. Site 543: oceanic reference site east of the Barbados Ridge

Complex, in: Biju-Duval, B., Moore, J.C., et al. (Eds.), Init. Repts DSDP, College Station, TX

(Ocean Drilling Program), pp. 1-72.

Shipboard Scientific Party, 1990. Site 800, in: Lancelot, Y., Larson, L.R., et al. (Eds.), Proc.

ODP, Init. Repts, College Station, TX (Ocean Drilling Program), pp. 33-89.

Shipboard Scientific Party, 1997. Site 1040, in: Kimura, G., Silver, E.A., Blum, P., al., e.

(Eds.), Proc. ODP, Init. Repts, College Station, TX (Ocean Drilling Program), pp. 1-58.

Shipboard Scientific Party, 2001a. Site 1174, in: Moore, G.F., Taira, A., Klaus, A., Becker, L.,

Boeckel, B., Cragg, B.A., Dean, A., Fergusson, C.L., Henry, P., Hirano, S., Hisamitsu, T.,

Hunze, S., Kastner, M., Maltman, A.J., Morgan, J.K., Murakami, Y., Saffer, D.M.,

Sanchez-Gomez, M., Screaton, E.J., Smith, D.C., Spivack, A.J., Steurer, J., Tobin, H.J., Ujiie,

K., Underwood, M.B., Wilson, M. (Eds.), Proc. ODP, Init. Repts, College Station, TX (Ocean

Drilling Program), pp. 1-149.

Shipboard Scientific Party, 2001c. Site 1175, in: Moore, G.F., Taira, A., Klaus, A., Becker, L.,

Boeckel, B., Cragg, B.A., Dean, A., Fergusson, C.L., Henry, P., Hirano, S., Hisamitsu, T.,

Hunze, S., Kastner, M., Maltman, A.J., Morgan, J.K., Murakami, Y., Saffer, D.M.,

Sanchez-Gomez, M., Screaton, E.J., Smith, D.C., Spivack, A.J., Steurer, J., Tobin, H.J., Ujiie, 
K., Underwood, M.B., Wilson, M. (Eds.), Proc. ODP, Init. Repts, College Station, TX (Ocean

Drilling Program), pp. 1-92.

Shipley, T.H., Moore, G.F., 1986. Sediment accretion, subduction and dewatering at the base

of the trench slope off Costa Rica: a seismic reflection view of the décollement. J. Geophys.

Res. 91, 2019-2028.

Shipley, T.H., Stoffa, P.L., Dean, D.F., 1990. Underthrust sediments, fluid migration paths, and mud volcanoes associated with the accretionary wedge off Costa Rica: Middle America Trench. J. Geophys. Res. 95, 8743-8752.

Sivan, O., Schrag, D.P., Murray, R.W., 2007. Rates of methanogenesis and methanotrophy in deep-sea sediments. Geobiology 5, 141-151.

Spinelli, G., Mozley, P.S., Tobin, H.J., Underwood, M.B., Hoffman, N.W., Bellew, G.M., 2007.

Diagenesis, sediment strength, and pore collapse in sediment approaching the Nankai Trough subduction zone. GSA Bull. 119, 377-390.

Spinelli, G., Saffer, D., 2004. Along-strike variations in underthrust sediment dewatering on the Nicoya margin, Costa Rica related to the updip limit of seismicity. Geophys. Res. Lett. 31, $1-5$.

Spinelli, G.A., Saffer, D.M., Underwood, M., 2006. Hydrogeologic responses to three-dimensional temperature variability, Costa Rica subduction margin. J. Geophys. Res. 
111.

Spivey, J.P., McCain, W.D., North, R., 2004. Estimating density, formation volume factor, compressibility, methane solubility, and viscosity for oilfield brines at temperatures from 0 to $275^{\circ} \mathrm{C}$, pressures to $200 \mathrm{MPa}$, and salinities to $5.7 \mathrm{~mole} / \mathrm{kg}$. J. Can. Petrol. Technol. 43, 52-60.

Stevenson, A.J., 1993. Generation, migration and resource potential for hydrocarbons in accretionary subduction systems - a large, unconventional hydrocarbon resource?, in: Howell, D.G. (Ed.), The future of energy gases. USGS Professional Papers 1570, Washington, pp. 353-363.

Suzuki, K., Hino, R., Ito, Y., Yamamoto, Y., Suzuki, S., Fujimoto, H., Shinohara, M., Abe, M., Kawaharada, Y., Hasegawa, Y., Kaneda, Y., 2012. Seismicity near the hypocenter of the 2011 off the Pacific coast of Tohoku earthquake deduced by using ocean bottom seismographic data Earth Planets and Space in press.

Syracuse, E.M., Van Keken, P.E., Abers, G.A., 2010. The global range of subduction zone thermal models. Phys. Earth Planet. In. 183, 73-90.

Tingay, M.R.P., Hillis, R.R., Swarbrick, R.E., Morley, C.K., Damit, A.R., 2009. Origin of overpressure and pore-pressure prediction in the Baram province, Brunei. AAPG Bull. 93, $51-74$

Tissot, B.P., Welte, D.H., 1978. Petroleum formation and occurrence: A new approach to oil 
and gas exploration. Springer-Verlag, New York.

Tobin, H.J., Saffer, D.M., 2009. Elevated fluid pressure and extreme mechanical weakness of a plate boundary thrust, Nankai Trough subduction zone. Geology 37, 679-682.

Toriumi, M., Teruya, J., 1988. Tectono-metamorphism of the Shimanto Belt. Modern Geology $12,303-324$.

Tsuji, T., Kimura, G., Okamoto, S., Kono, F., Mochinaga, H., Saeki, T., Tokuyama, H., 2006.

Modern and ancient seismogenic out-of-sequence thrusts in the Nankai accretionary prism:

Comparison of laboratory-derived physical properties and seismic reflection data. Geophys.

Res. Lett. 33, 1-5.

Uehara, S.I., Shimamoto, T., 2004. Gas permeability evolution of cataclasite and fault gouge in triaxial compression and implications for changes in fault-zone permeability structure through the earthquake cycle. Tectonophysics 378, 183-195.

Ungerer, P., Behar, E., Discamps, D., 1981. Tentative calculation of the overall volume expansion of organic matter during hydrocarbon genesis from geochemistry data. Implications for primary migration, Advances in Organic Geochemistry. John Wiley \& Sons. Ungerer, P., Espitalié, J., Marquis, F., Durand, B., 1986. Use of kinetic models of organic matter evolution for the reconstruction of paleotemperatures, in: Burrus, J. (Ed.), Thermal modeling in sedimentary basins. Technip, Paris, pp. 531-546. 
Uyeda, S., Kanamori, H., 1979. Backarc opening and the mode of subduction. J. Geophys.

Res. 84, 1049-1061.

Van Krevelen, D.W., 1961. Coal: Typology, chemistry, physics, constitution. Elsevier, Amsterdam.

Vannucchi, P., Scholl, D.W., Meschede, M., McDougall-Reid, K., 2001. Tectonic erosion and consequent collapse of the Pacific margin of Costa Rica: Combined implications from ODP Leg 170, seismic offshore data, and regional geology of the Nicoya Peninsula. Tectonics 20, 649-668.

Velde, B., Vasseur, G., 1992. Estimation of the diagenetic smectite to illite transformation in time-temperature space. Am. Mineral. 77, 967-976.

Vidal, O., Dubacq, B., 2009. Thermodynamic modelling of clay dehydration, stability and compositional evolution with temperature, pressure and $\mathrm{H} 2 \mathrm{O}$ activity. Geochimica et Cosmochimica Acta 73, 6544-6564.

Vigny, C., Socquet, A., Peyrat, S., Ruegg, J.-C., Métois, M., et al., 2011. The 2010 Mw 8.8 Maule megathrust earthquake of Central Chile, monitored by GPS. Science 332, 1417-1421. Völker, D., Grevemeyer, I., Stipp, M., Wang, K., He, J., 2011. Thermal control of the seismogenic zone of southern central Chile. J. Geophys. Res. 116, 1-20.

von Huene, R., Klaeschen, D., Gutscher, M.A., Fruehn, J., 1998. Mass and fluid flux during 
accretion at the Alaskan margin. GSA Bull. 110, 468-482.

Von Huene, R., Lallemand, S., 1990. Tectonic erosion along the Japan and Peru convergent margins. GSA Bull. 102, 704-720.

Von Huene, R., Langseth, M., Nasu, N., Okada, H., 1980. Summary, Japan Trench Transect, in: Lee, M., Stout, L.N. (Eds.), DSDP, Init. Rpts, vol. 56-57, p. doi:10.2973/dsdp.proc.5657.2111.1980.

Von Huene, R., Ranero, C.R., Vannucchi, P., 2004. Generic model of subduction erosion. Geology 32, 913-916.

Von Huene, R., Scholl, D.W., 1991. Observations at convergent margins concerning sediment subduction, subduction erosion, and the growth of continental crust. Rev. Geophys. 29, 279-316.

Vrolijk, P., 1990. On the mechanical role of smectite in subduction zones. Geology 18, 703-707.

Vrolijk, P., Chambers, S.R., Gieskes, J.M., O'Neil, J., 1990. Stable isotope ratios of interstitial fluids from the Northern Barbados accretionary prism, ODP Leg 110, in: Moore, J.C., et al.

(Eds.), Proc. ODP, Sci. Results, pp. 181-205.

Vrolijk, P., Myers, G., Moore, J.C., 1988. Warm fluid migration along tectonic melanges in the Kodiak accretionary complex, Alaska. J. Geophys. Res. 93, 10,313-310,324. 
Wada, I., Wang, K., 2009. Common depth of slab-mantle decoupling: Reconciling diversity and uniformity of subduction zones. G-cubed 10, 1-36.

Wagner, W., Pruss, A., 2002. The IAPWS formulation 1995 for the thermodynamic properties of ordinary water substance for general and scientific use. J. Phys. Chem. Ref. Data 31, 387-535.

Wellsbury, P., Mather, I., Parkes, J.R., 2002. Geomicrobiology of deep, low organic carbon sediments in the Woodlark Basin, Paciфc Ocean. FEMS Microbiology 42, 59-70.

Westbrook, G.K., Mascle, A., Biju-Duval, B., 1984. Geophysics and the structure of the Lesser Antilles forearc, in: Biju-Duval, B., Moore, J.C., et al. (Eds.), Proc. DSDP, Init. Repts, vol 78A, p. doi:10.2973/dsdp.proc.2978a.2102.1984.

Wibberley, C., 2002. Hydraulic diffusivity of fault gouge zones and implications for thermal pressurization during seismic slip. Earth Planets Space 54, 1153-1171.

Wibberley, C., Shimamoto, T., 2005. Earthquake slip weakening and asperities explained by thermal pressurization. Nature 436, 689-692.

Wiersberg, T., Schleicher, A.M., Horiguchi, K., Doan, M.-L., Eguchi, N., Erzinger, J., 2015. Origin and in situ concentrations of hydrocarbons in the Kumano forearc basin from drilling mud gas monitoring during IODP NanTroSEIZE Exp. 319. Applied Geochemistry 61, 205-216. 
Yamaguchi, A., Ujiie, K., Nakai, S., Kimura, G., 2012. Sources and physicochemical characteristics of fluids along a subduction-zone megathrust: A geochemical approach using syn-tectonic mineral veins in the Mugi mélange, Shimanto accretionary complex. G-cubed 13, $1-22$.

Yang, Y., Aplin, A.C., 2007. Permeability and petrophysical properties of 30 natural mudstones. J. Geophys. Res. 112, 1-14. doi:10.1029/2005JB004243.

Yang, Y., Aplin, A.C., 2010. A permeability-porosity relationship for mudstones. Mar. Petrol. Geol. 27, 1692-1697.

Yu, Z., Lerche, I., 1996. Modelling abnormal pressure development in sandstone/shale basins. Mar. Petrol. Geol. 13, 179-193.

Yue, H., Lay, T., Schwartz, S., Rivera, L., Protti, M., Dixon, T.H., Owen, S., Newman, A.V., 2013. The 5 September 2012 Nicoya, Costa RicaMw 7.6 earthquake rupture process from joint inversion of high-rate GPS, strong-motion, and teleseismic P wave data and its relationship to adjacent plate boundary interface properties. J. Geophys. Res. 118, $5453-5466$. 
Table 1

\begin{tabular}{|c|c|c|c|c|c|c|c|c|c|c|c|}
\hline Sample & $\begin{array}{l}\text { S1 (mg } \\
\text { HC/g } \\
\text { rock) }\end{array}$ & $\begin{array}{c}\mathrm{S} 2 \text { (mg } \\
\mathrm{HC} / \mathrm{g} \\
\text { rock) }\end{array}$ & TpeakS2 $\left({ }^{\circ} \mathrm{C}\right)$ & $\begin{array}{l}\text { Tmax } \\
\left({ }^{\circ} \mathrm{C}\right)\end{array}$ & $\begin{array}{c}\text { S3 (mg } \\
\text { co/g } \\
\text { rock) }\end{array}$ & $\begin{array}{c}\text { S4 } \quad \text { (mg } \\
\mathrm{cO} / \mathrm{g} \\
\text { rock) }\end{array}$ & $\mathrm{PC}(\%) \mathrm{c}$ & $\mathrm{RC}(\%) \mathrm{c}$ & TOC(\%) & $\begin{array}{l}\mathrm{HI} \text { (mg } \\
\mathrm{HC} / \mathrm{g} \\
\mathrm{TOC})\end{array}$ & $\begin{array}{l}\text { OI (mg } \\
\mathrm{CO}_{2} / \mathrm{g} \\
\mathrm{TOC})\end{array}$ \\
\hline 101 & 0,01 & 0,06 & 637 & 595 & 0,29 & 3,27 & 0,01 & 0,11 & 0,12 & 50 & 242 \\
\hline 102 & 0,01 & 0,09 & 393 & 351 & 0,23 & 16,01 & 0,02 & 0,57 & 0,59 & 15 & 39 \\
\hline 54 & 0,01 & 0,08 & 639 & 597 & 0,27 & 13,47 & 0,02 & 0,55 & 0,57 & 14 & 47 \\
\hline 46 & 0 & 0,07 & 548 & 506 & 0,41 & 4,95 & 0,02 & 0,17 & 0,19 & 37 & 216 \\
\hline 64 & 0,01 & 0,07 & 646 & 604 & 0,22 & 12,72 & 0,04 & 0,5 & 0,54 & 13 & 41 \\
\hline 69 & 0 & 0,03 & 530 & 488 & 0,12 & 8,31 & 0,01 & 0,31 & 0,32 & 9 & 38 \\
\hline 76 & 0 & 0,06 & 640 & 598 & 0,08 & 6,06 & 0,01 & 0,23 & 0,24 & 25 & 33 \\
\hline 82 & 0,01 & 0,08 & 533 & 491 & 0,41 & 10 & 0,02 & 0,36 & 0,38 & 21 & 108 \\
\hline 83 & 0,01 & 0,06 & 647 & 605 & 0,22 & 14,56 & 0,02 & 0,59 & 0,61 & 10 & 36 \\
\hline 92 & 0 & 0,05 & 360 & 318 & 0,08 & 0,12 & 0,01 & 0 & 0,01 & & \\
\hline 85 & 0,01 & 0,1 & 646 & 604 & 0,28 & 12,05 & 0,02 & 0,48 & 0,5 & 20 & 56 \\
\hline 200 & 0,01 & 0,07 & 533 & 491 & 0,45 & 9,32 & 0,02 & 0,32 & 0,34 & 21 & 132 \\
\hline
\end{tabular}


Table 2

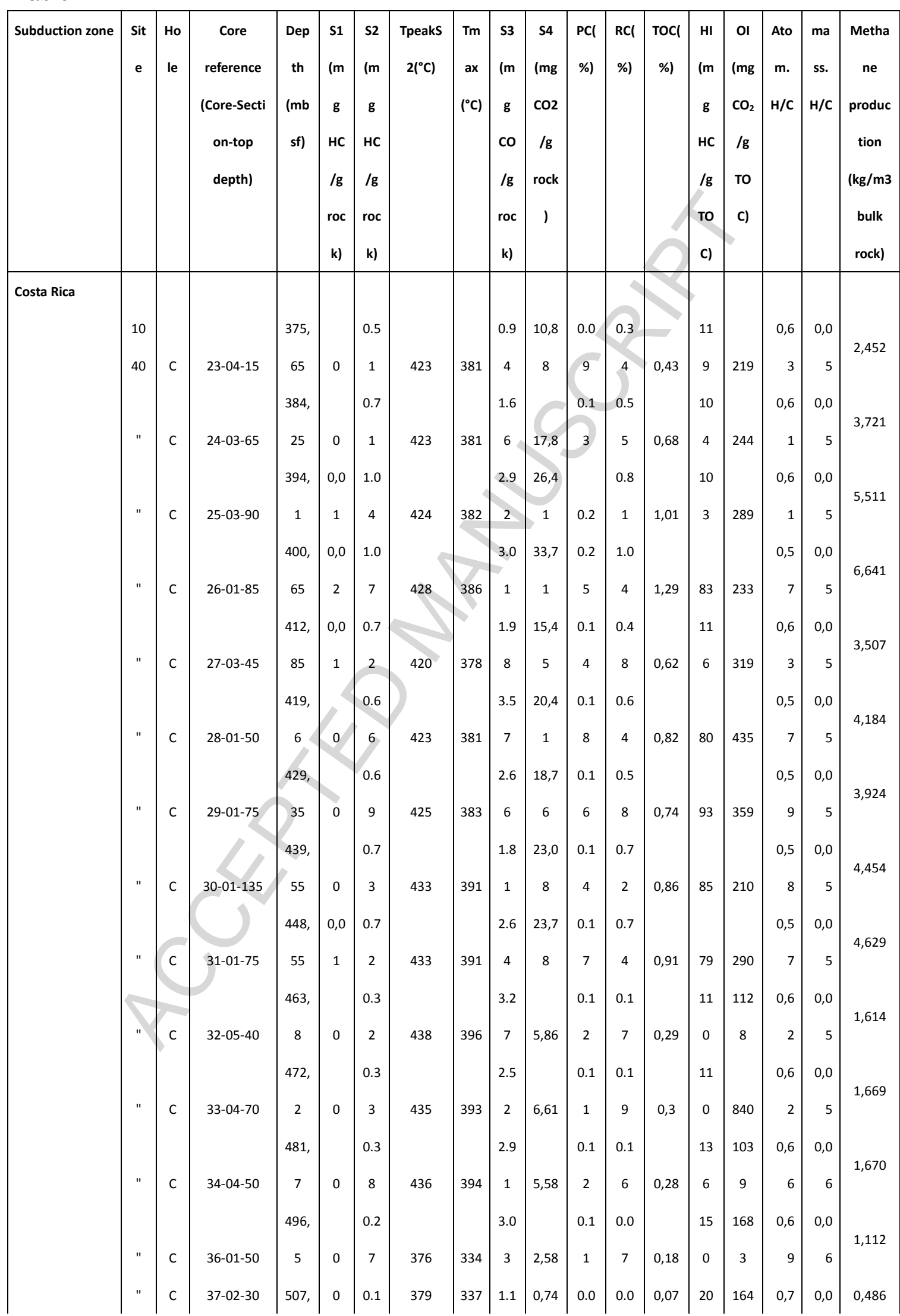




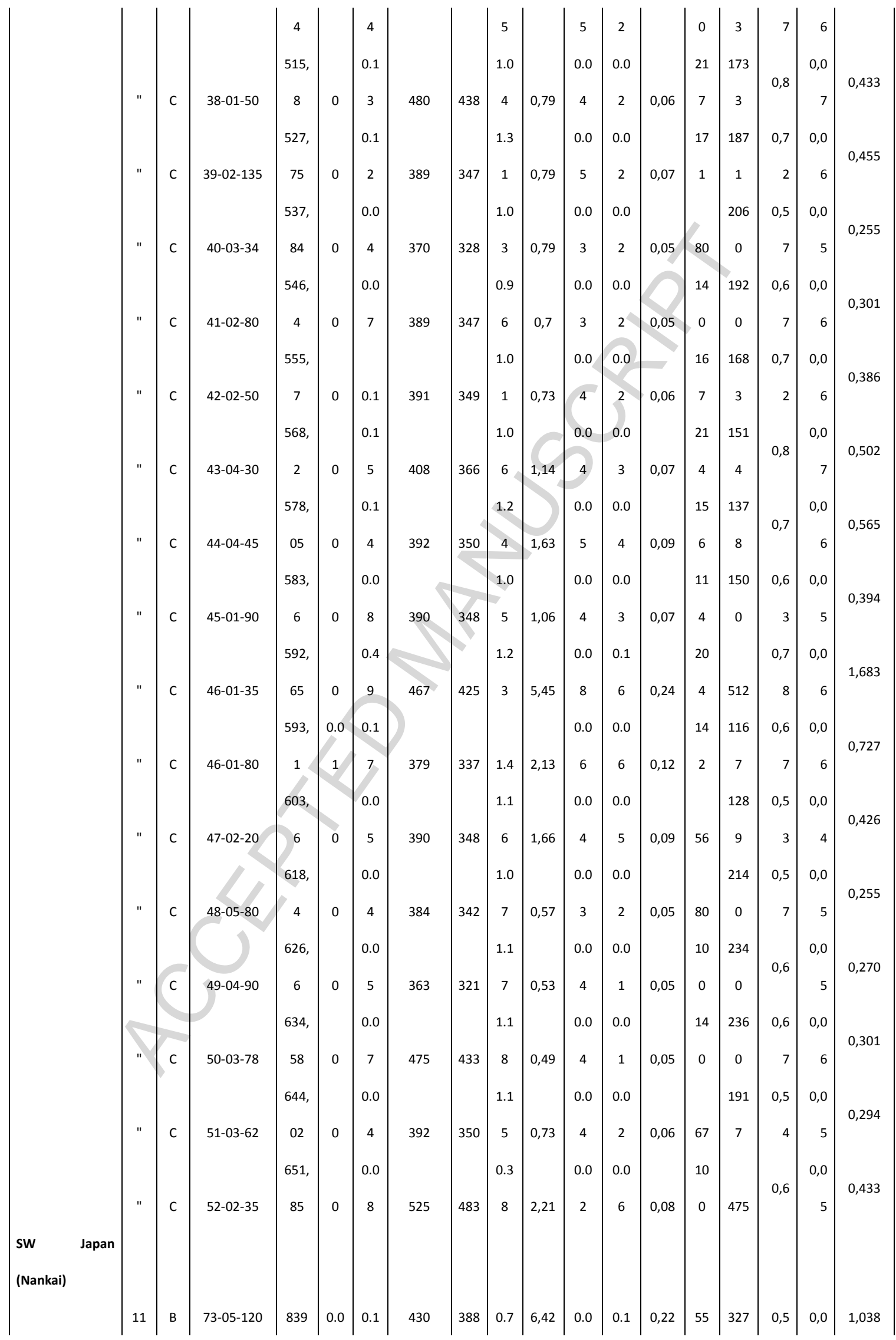




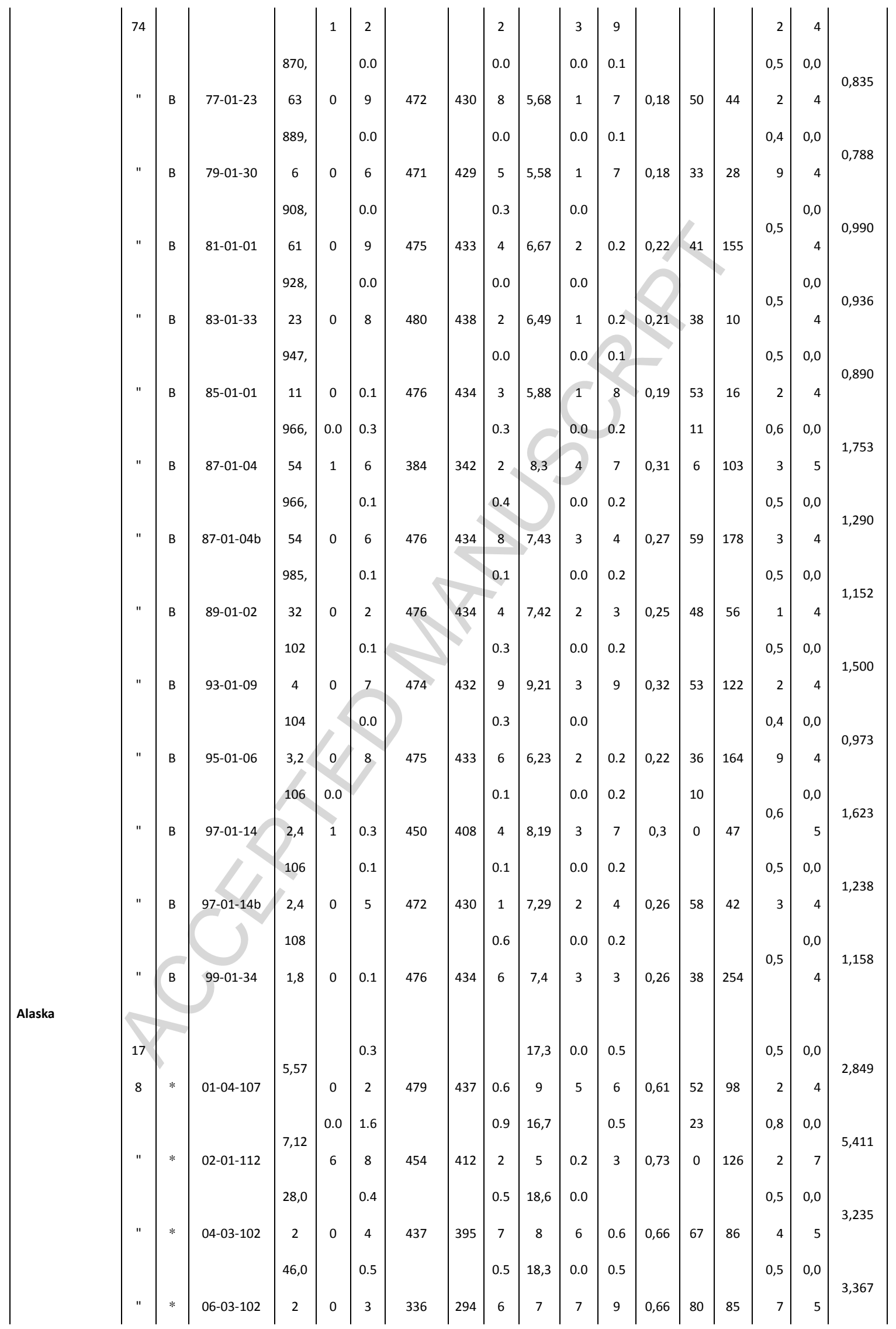




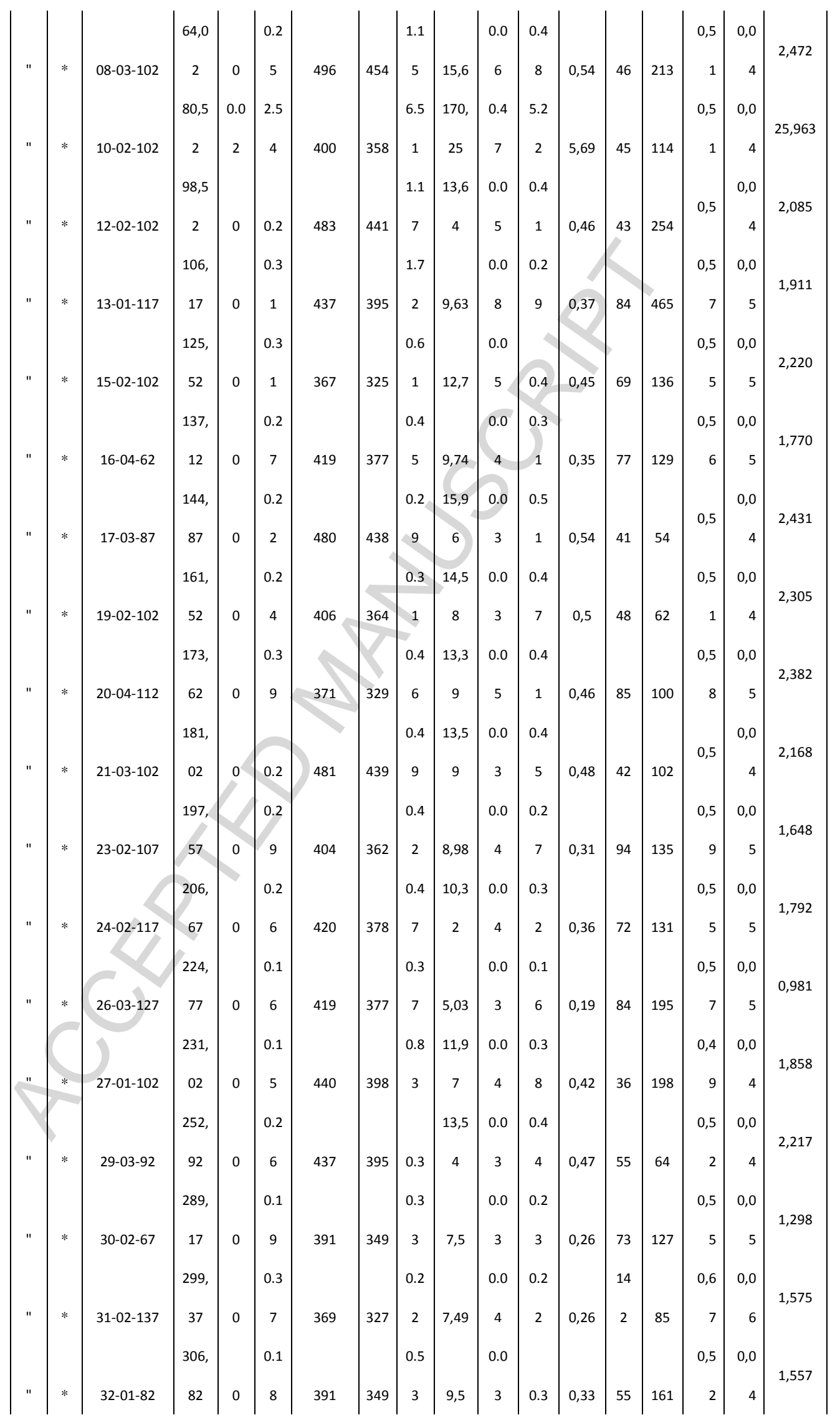




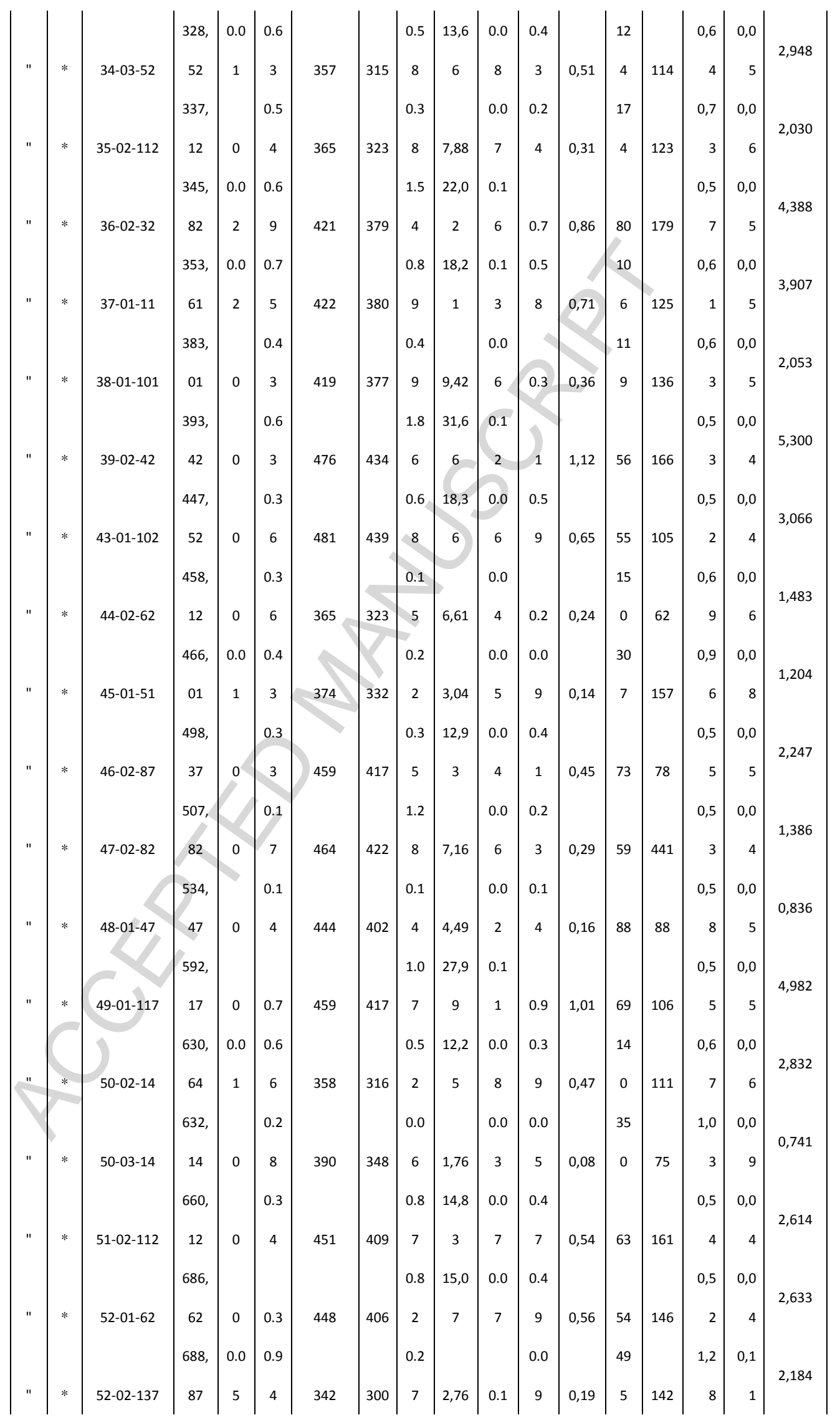




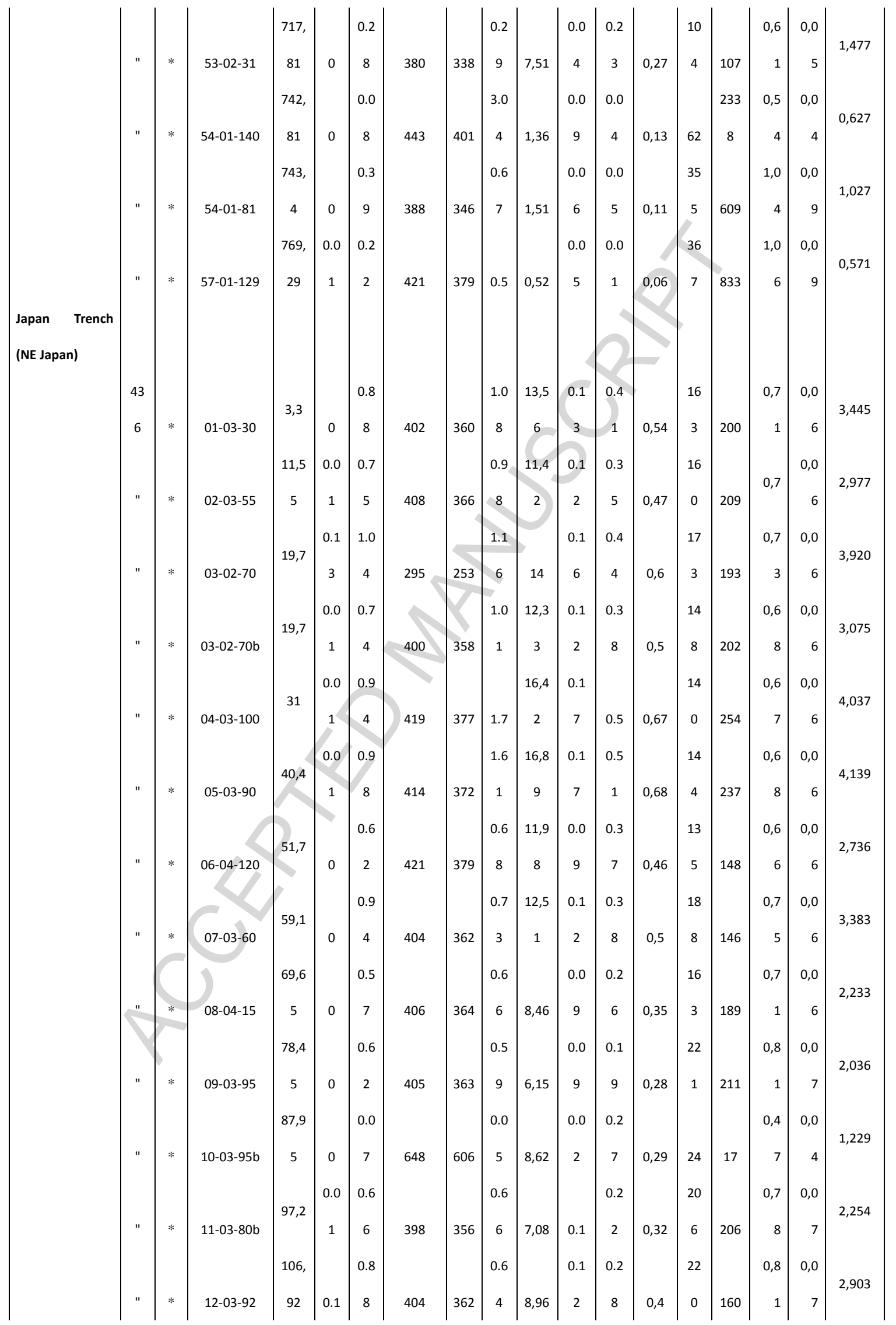




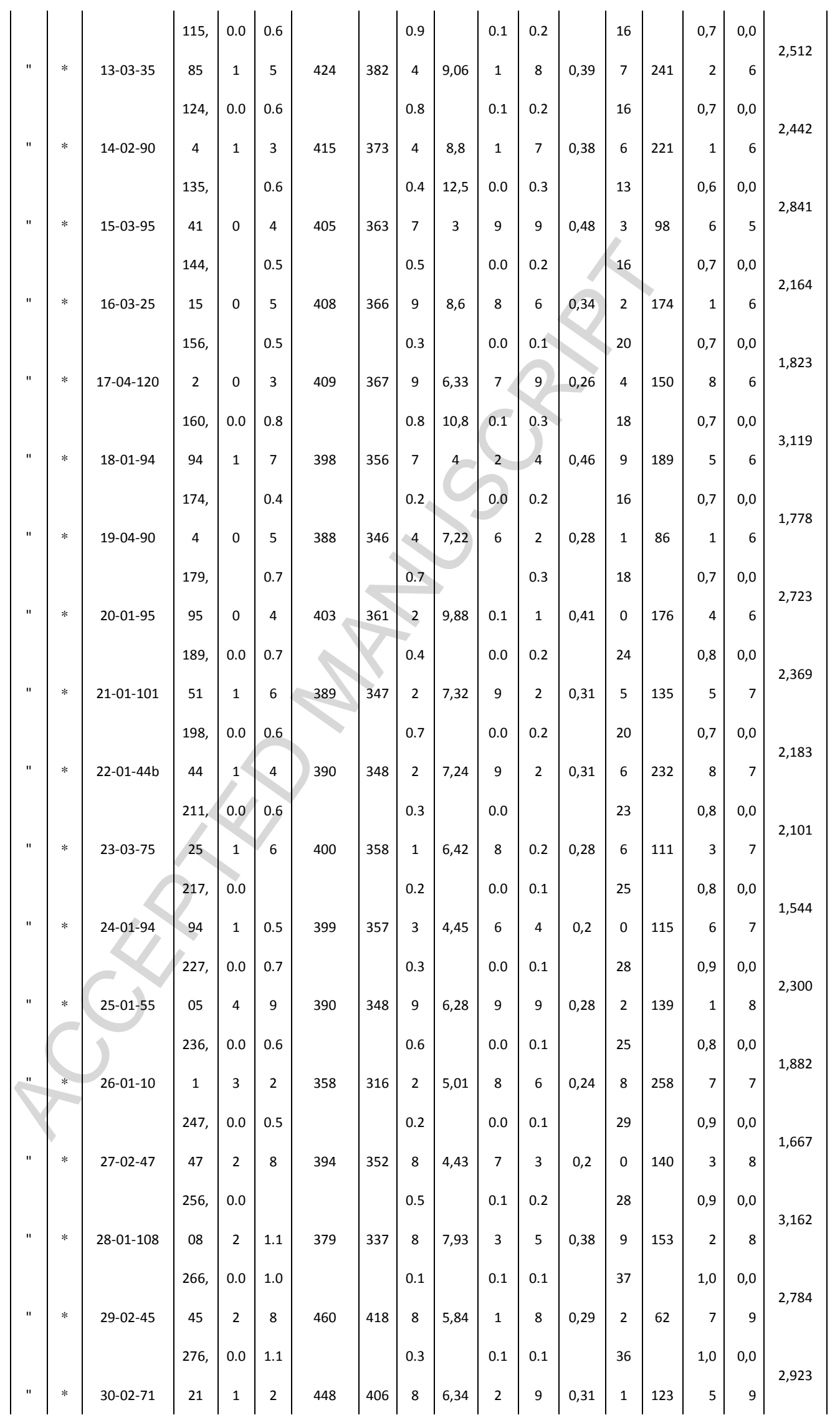




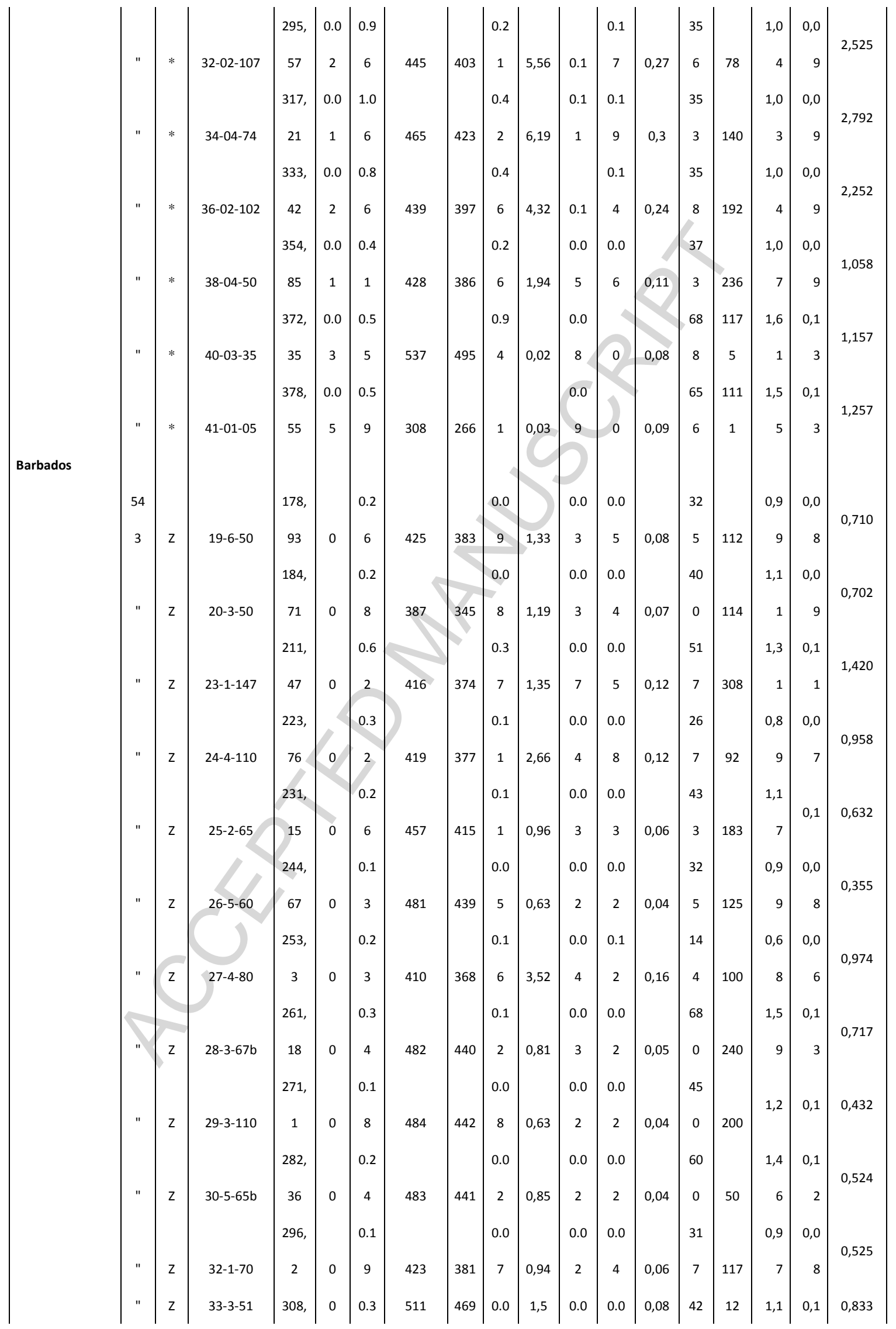




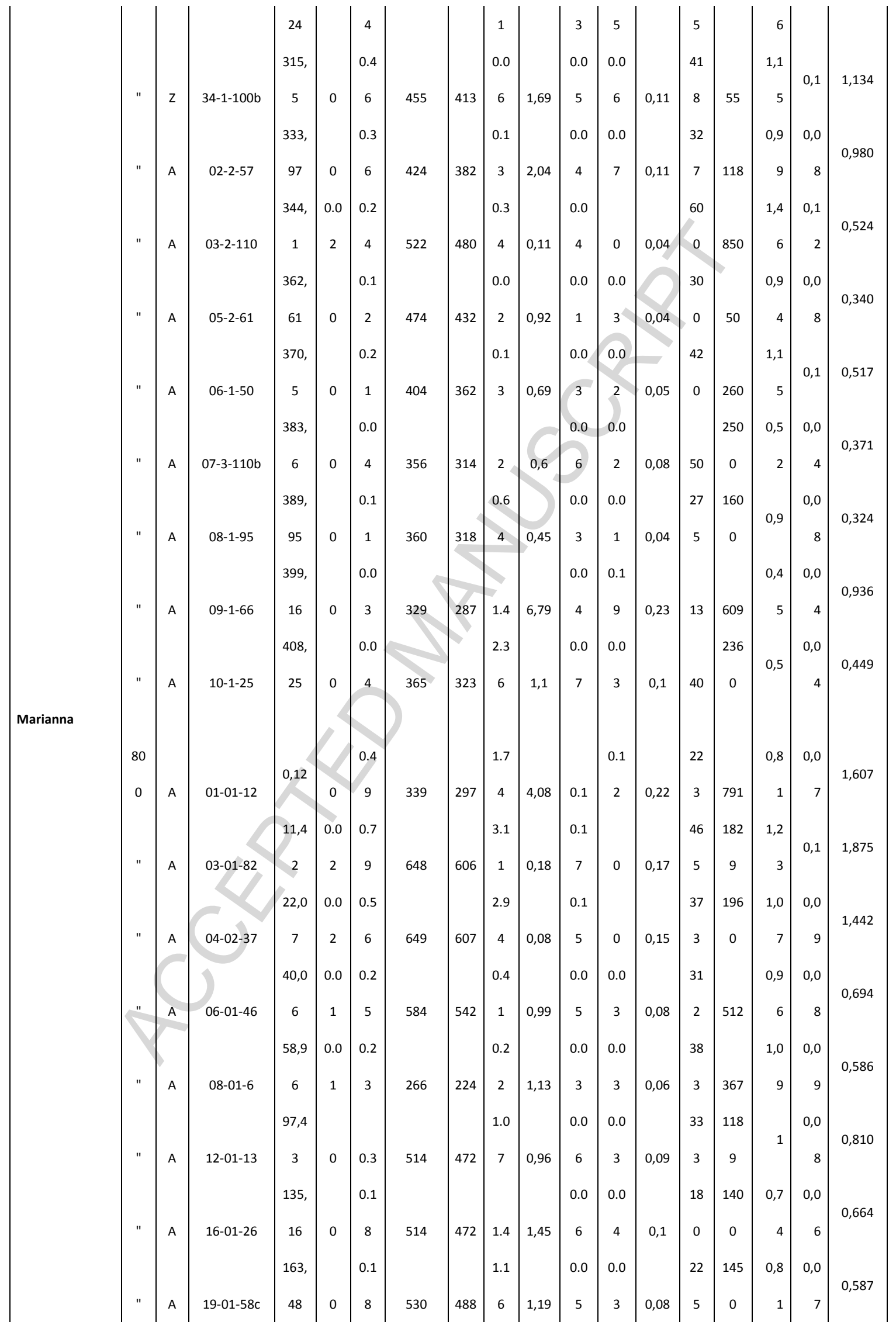




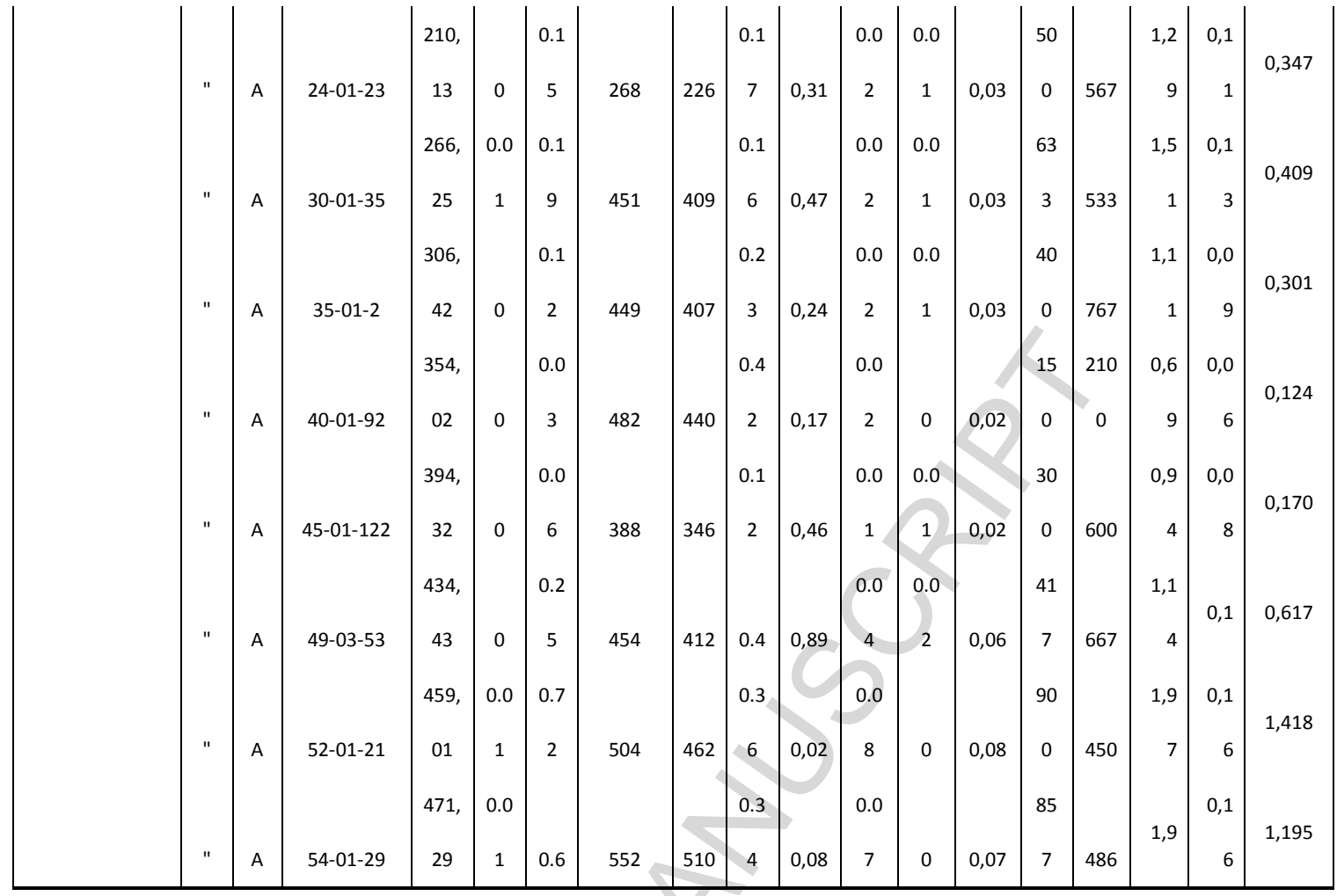




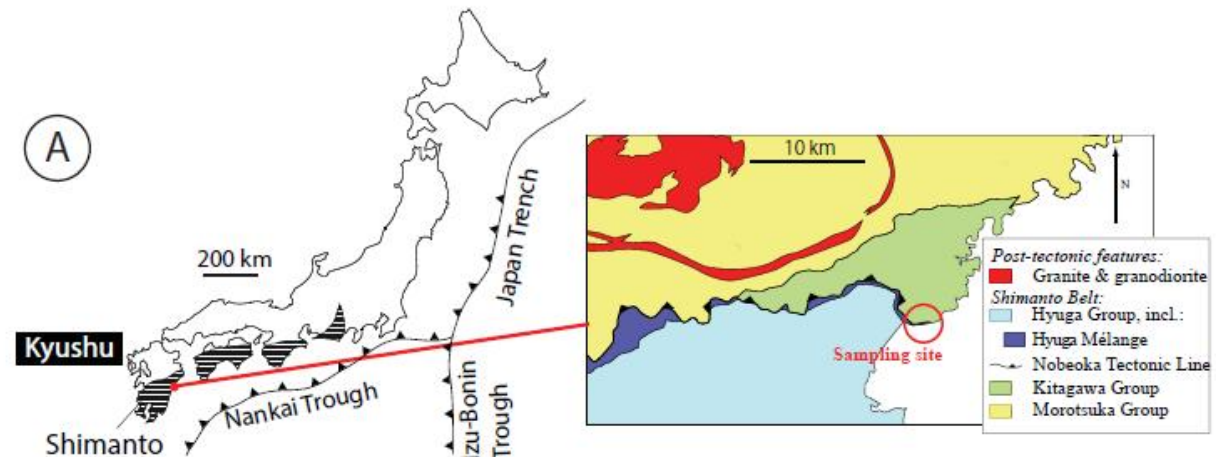

Belt

(B)

Focal plane depth decrease

(B)

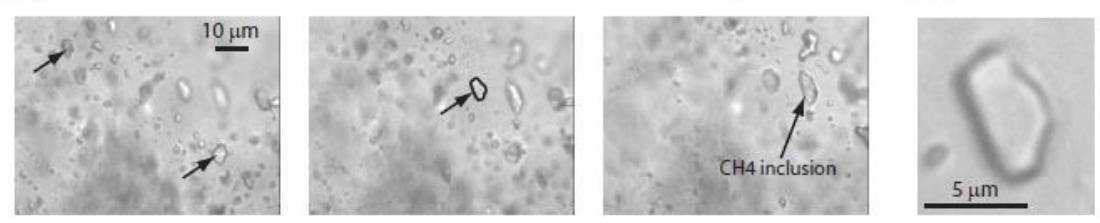

Figure 1: A) Sample site of quartz veins containing the studied fluid inclusions in the Hyuga mélange unit from the Shimanto Belt, on Kyushu Island, Japan. B) Photomicrographs of secondary methane-rich fluid inclusions. The three pictures, taken by slightly changing the focus of the microscope, highlight the fluid inclusion distribution along a plane at low angle with the surface of the thin section, corresponding to a healed microfracture. $\mathrm{B}^{\prime}$ ) Close-up view of a characteristic fluid inclusion, in the center of photomicrograph in B). The inclusion has a regular shape and is filled by a single, methane-rich phase. 


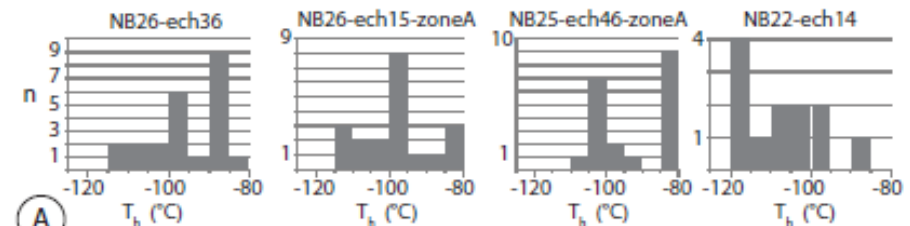

(A) $T^{-120} T_{h}^{-100}(C)$

$\begin{array}{cc}120 & -100 \\ T_{h}(C)\end{array}$
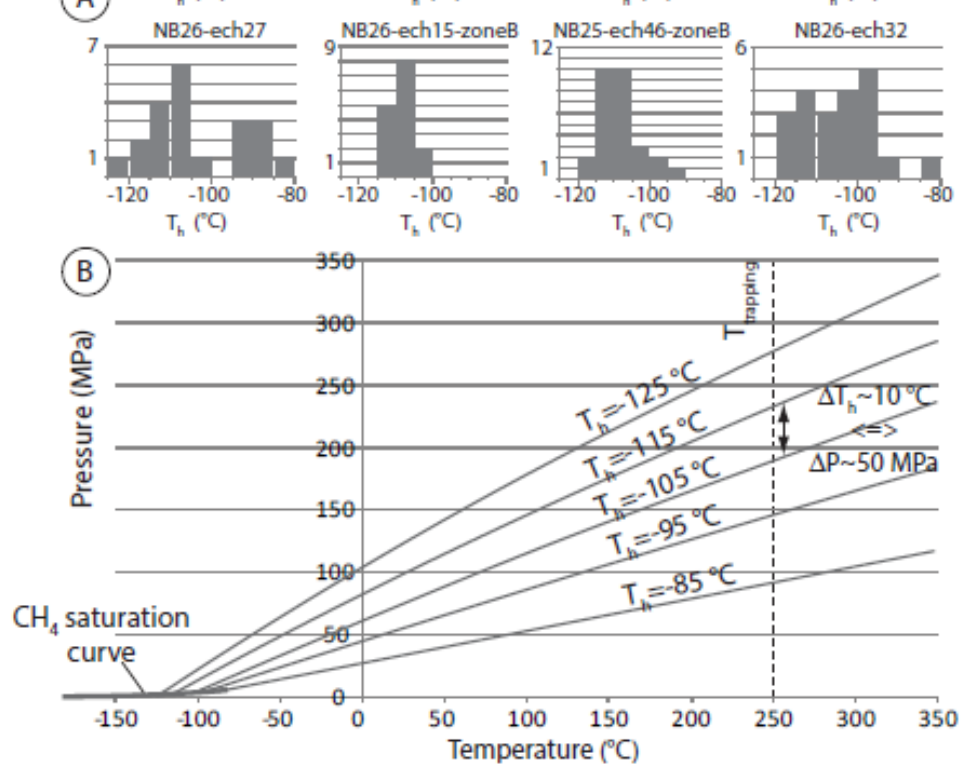

Figure 2: A) Temperatures of methane homogenization of methane-rich fluid inclusions. Each plot corresponds to inclusions along a single plane. B) Trapping pressure of the fluid, inferred as the intersection of the isochore of its host inclusion with the $\mathrm{T} 250^{\circ} \mathrm{C}$ isotherm. The large scatter in homogenization temperatures of the inclusions in a given plane reflects the large variations in fluid pressure over the short time necessary for the microfracture plane to heal. For example, a $\Delta \mathrm{T}$ of $\sim 10^{\circ} \mathrm{C}$ in homogenization temperatures converts into a pressure variation $\triangle \mathrm{P} \sim 50 \mathrm{MPa}$. 


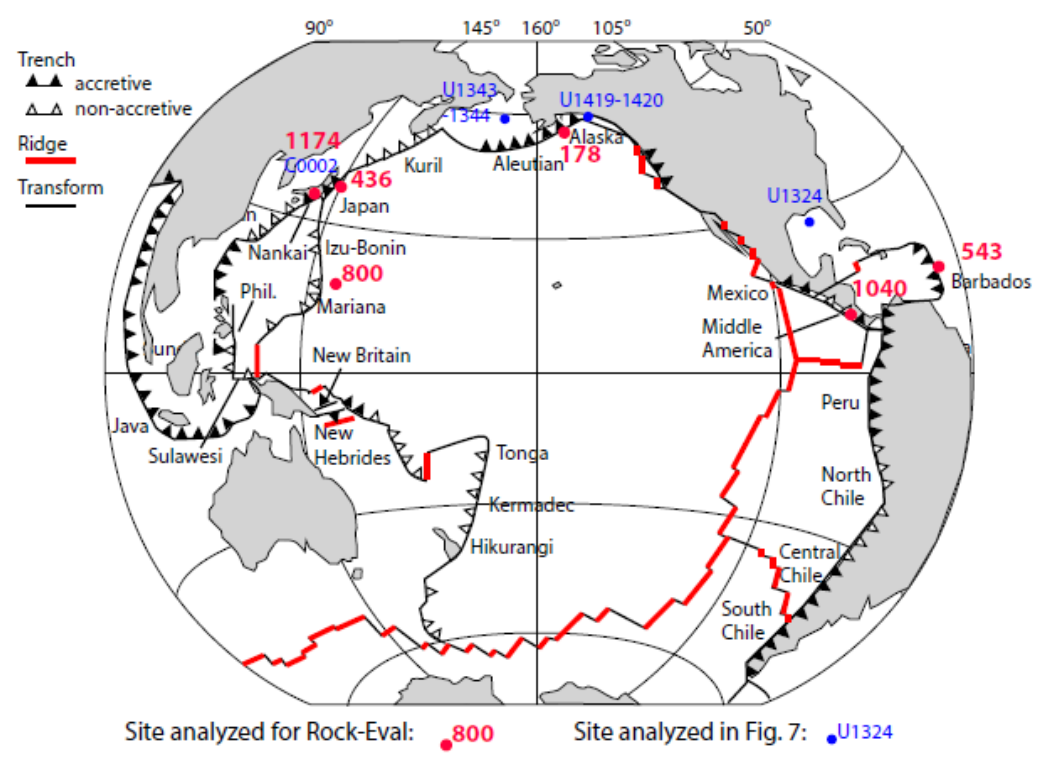

Figure 3: Distribution of core samples analyzed in Fig. 6, 7 and Tab. 2. The underlying map, showing the plate boundary nature, is adapted from Von Huene and Scholl (1991). 


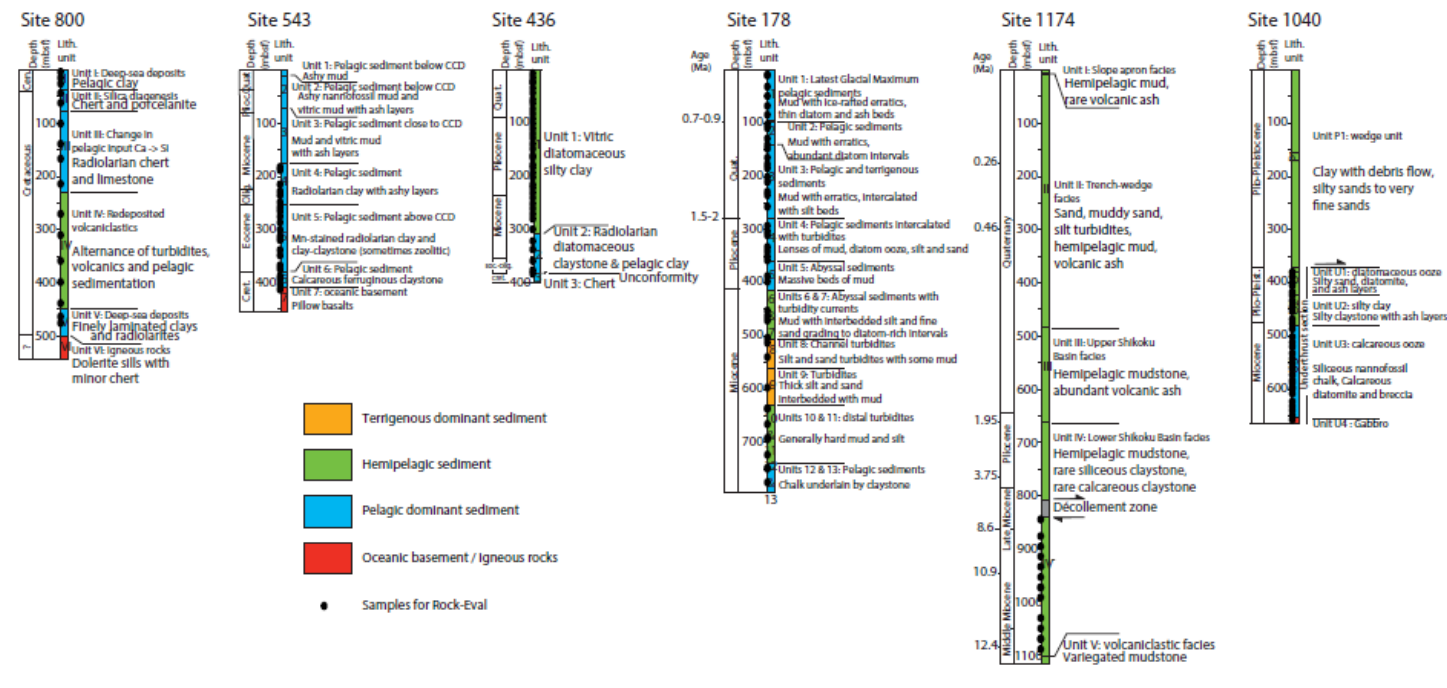

Figure 4: Lithostratigraphic column of all core samples analyzed with Rock-Eval (Figs. 5, 6 and Tab. 2). 


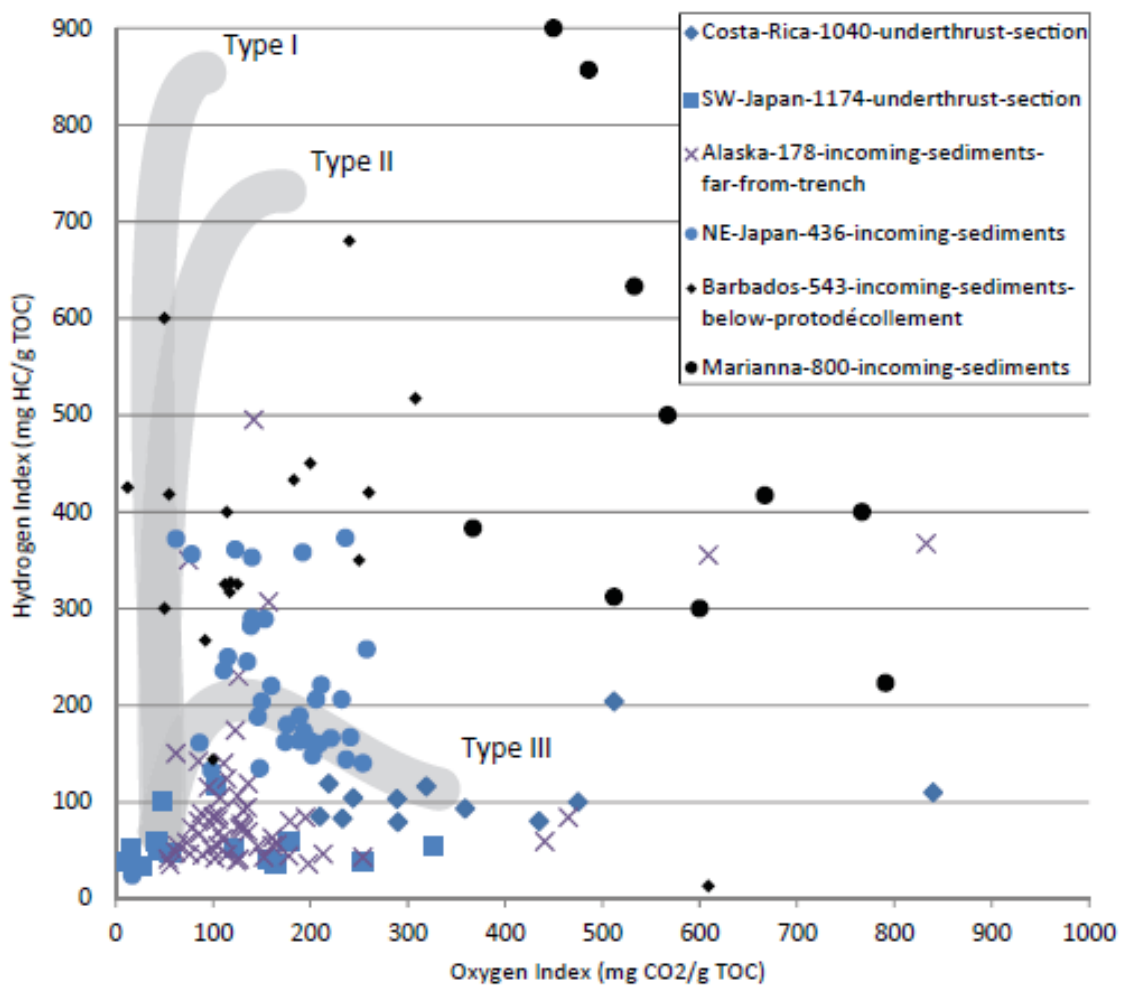

Figure 5: Rock-Eval analyses of ODP/DSPS/IODP sediment samples shown in a pseudo Van-Krevelen diagram, with the three generic types of $\mathrm{M}$. 


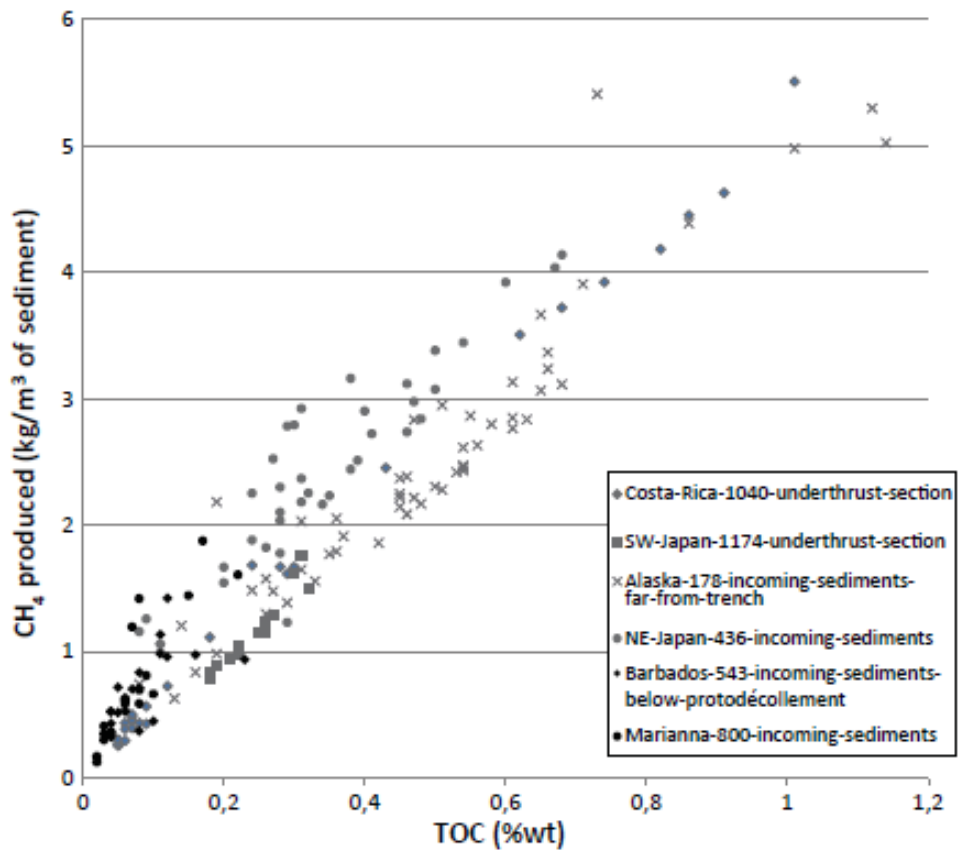

Figure 6: Potential methane productivity as a function of their ToC for sediments in worldwide subduction zones. Methane productivity is derived from TOC and HI parameters given by RockEval analysis of sediments core samples (see 4.2.2). Blue/black symbols refer to ocean-ocean/ ocean-continent subduction zones, respectively. 


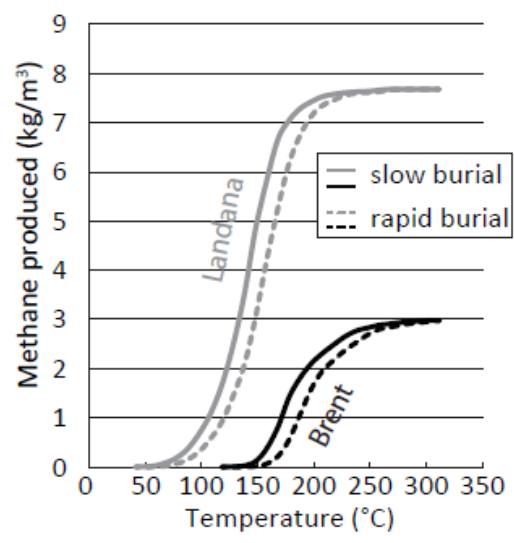

Figure 7: Cracking of $O M$ resulting from the increase in temperature, calculated using the software Temis Suite 2008 from the Beicip Franlab and a TOC of $0.5 \%$ t. We considered two kinds of OM, representative of marine ("Landana") and terrigenous ("Brent") kerogene, and rapid $\left(300^{\circ} \mathrm{C}\right.$ in $\left.1.5 \mathrm{Ma}\right)$ or slow $\left(300^{\circ} \mathrm{C}\right.$ in $\left.15 \mathrm{Ma}\right)$ burial-increase in $\mathrm{T}$. For terrigeneous

material, irrespectively of burial rate, cracking occurs principally in the $\mathrm{T}$ range $150-250^{\circ}$ c. 
(A)

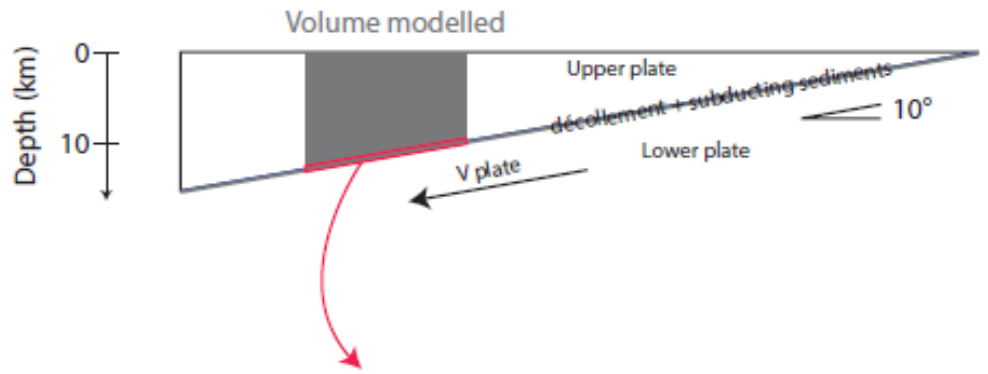

(B)

\section{fluid flow out:}

-through the upper plate

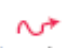

$\leadsto$

$150^{\circ} \mathrm{C}$

-through the overpressured décollement $\sim$

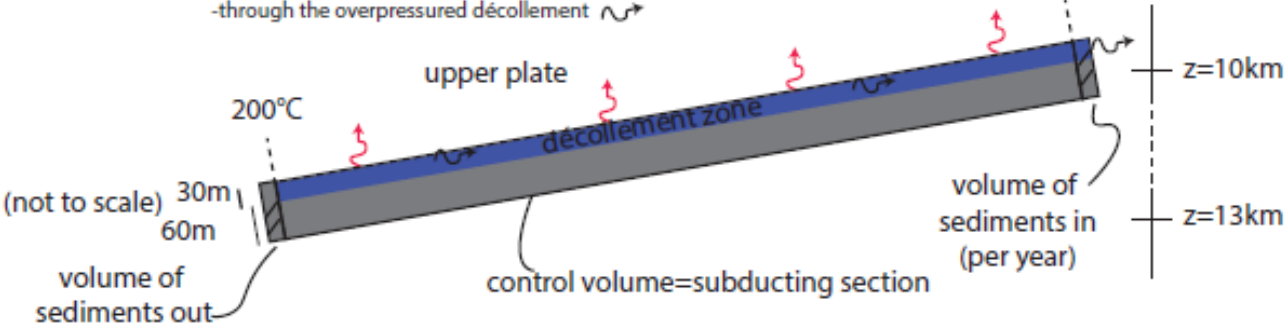

sedimentso

(per year)

Figure 8: Model of thermogenic cracking of OM. (A) The domain modelled numerically in section 8 is shown as the grey area. It comprises a thin section of subducting sediments at its bottom and the overlying upper plate. (B) Close-up view of the subducting sediments at the bottom of the modelled domain. It is composed of $60 \mathrm{~m}$ of undeformed material below a $\sim 30 \mathrm{~m}-$ thick décollement zone accommodating all the deformation. The $90 \mathrm{~m}$-thick section (=control volume) is affected by thermal cracking of OM. The upper limit of the control volume is at a depth of $\sim 10 \mathrm{~km}$, corresponding to the isotherm $150^{\circ} \mathrm{C}$ for a gradient of $15^{\circ} \mathrm{C} / \mathrm{km}$. The overpressure within the control volume and above is the result of the balance between gas production and gas leakage (through the décollement and the upper plate). 


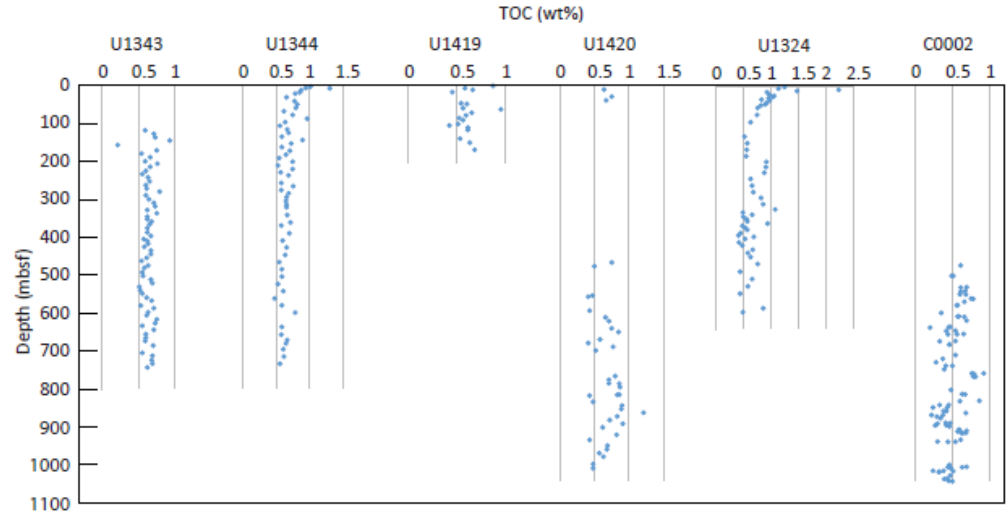

Figure 9: TOC as function of depth in several deep sea sediment columns. Drilling sites are located at a fixed position with respect to the source of OM, so that the supply of oM can be considered as constant with time of deposition/depth in the column. The associated lithostratigraphic columns are described in Supplemental File. 


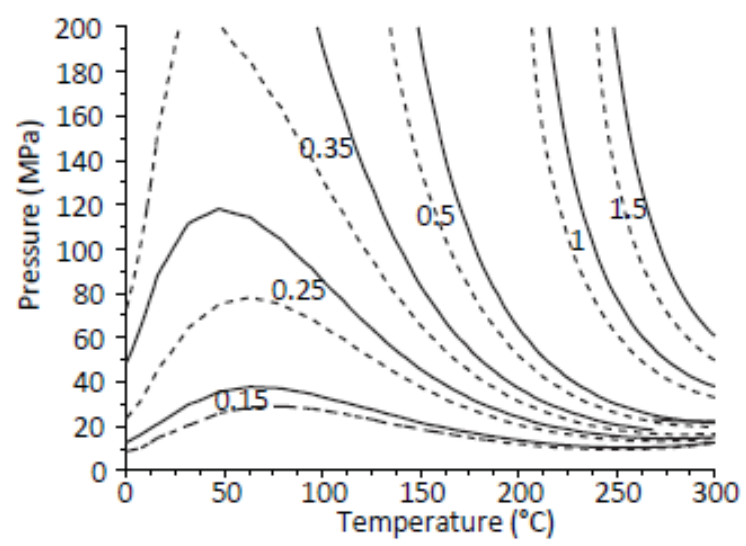

Figure 10: Curves of iso-solubility in mol/kg of methane in pure water (dashed lines) and seawater (solid lines), calculated from Duan and Mao (2006). 


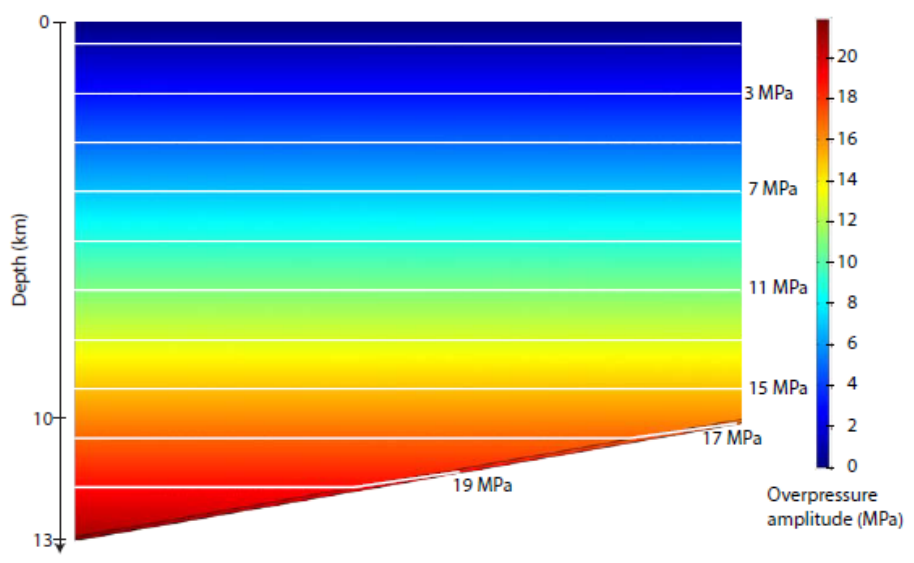

Figure 11: Field of overpressure ( $\triangle \mathrm{P}=\mathrm{Pf}$ - Pf hyd) for the case where permeability is set at 10-21m2 for the upper plate and at 10-22m2 for the subducting sediment. The maximum overpressure, $22 \mathrm{MPa}$, is located in the lower left corner of the model. 


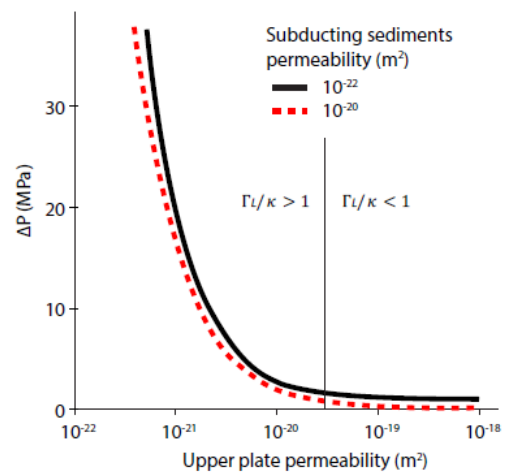

Figure 12: Maximum overpressure $\Delta \mathrm{P}$ as a function of subducting sediment and upper plate permeability. Overpressure amplitude is controlled by upper plate permeability. Significant, i.e. >10MPa, overpressure occur only when the permeability of the upper plate is lower than $\sim 2$ 10-21m2. The criterion $\Gamma \mathrm{L} / \mathrm{K}=1$ is defined in Neuzil (1995) as the threshold for overpressure to develop (see 9.3.3). 
(A)

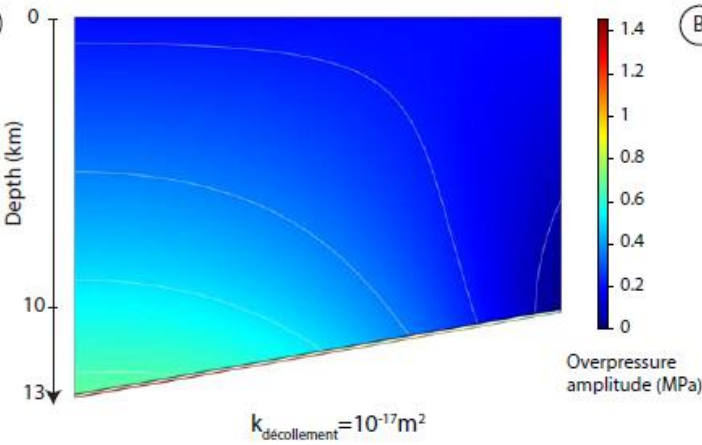

(B)

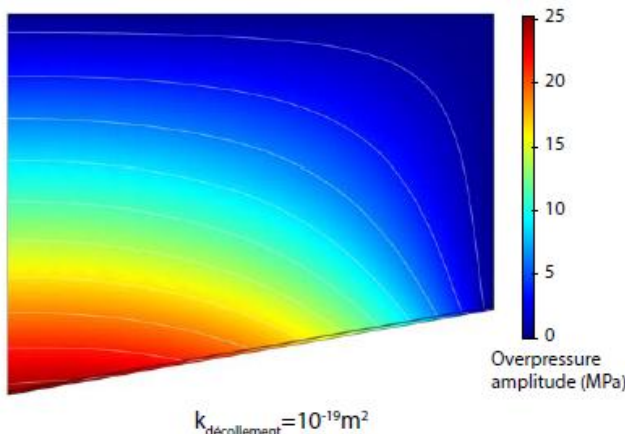

Figure 13: Field of overpressure ( $\triangle \mathrm{P}=\mathrm{Pf}$ - Pf_hyd) for the case where permeability is set at $10-17 \mathrm{~m} 2$ (A) and $10-19 \mathrm{~m} 2$ (B) for the décollement zone and at $5.10-22 \mathrm{~m} 2$ for the upper plate. In the case (A) where the décollement has a relatively high permeability, it enables an efficient drainage of the subducting sediments and prevents large overpressure to develop. The case of a low permeability décollement zone (B) is similar to the models where the outflow is vertical. 


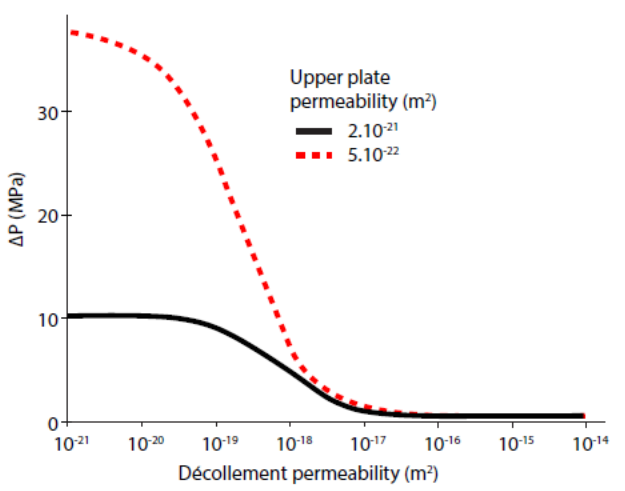

Figure 14: Maximum overpressure $\Delta \mathrm{P}$ as a function of décollement and upper plate permeability. Décollement with a permeability larger than $10-18 \mathrm{~m} 2$ efficiently drains the fluid out of subducting sediments and dissipates overpressure, while décollement permeability lower than $\sim 10-18 \mathrm{~m} 2$ results in significant overpressure build-up. 


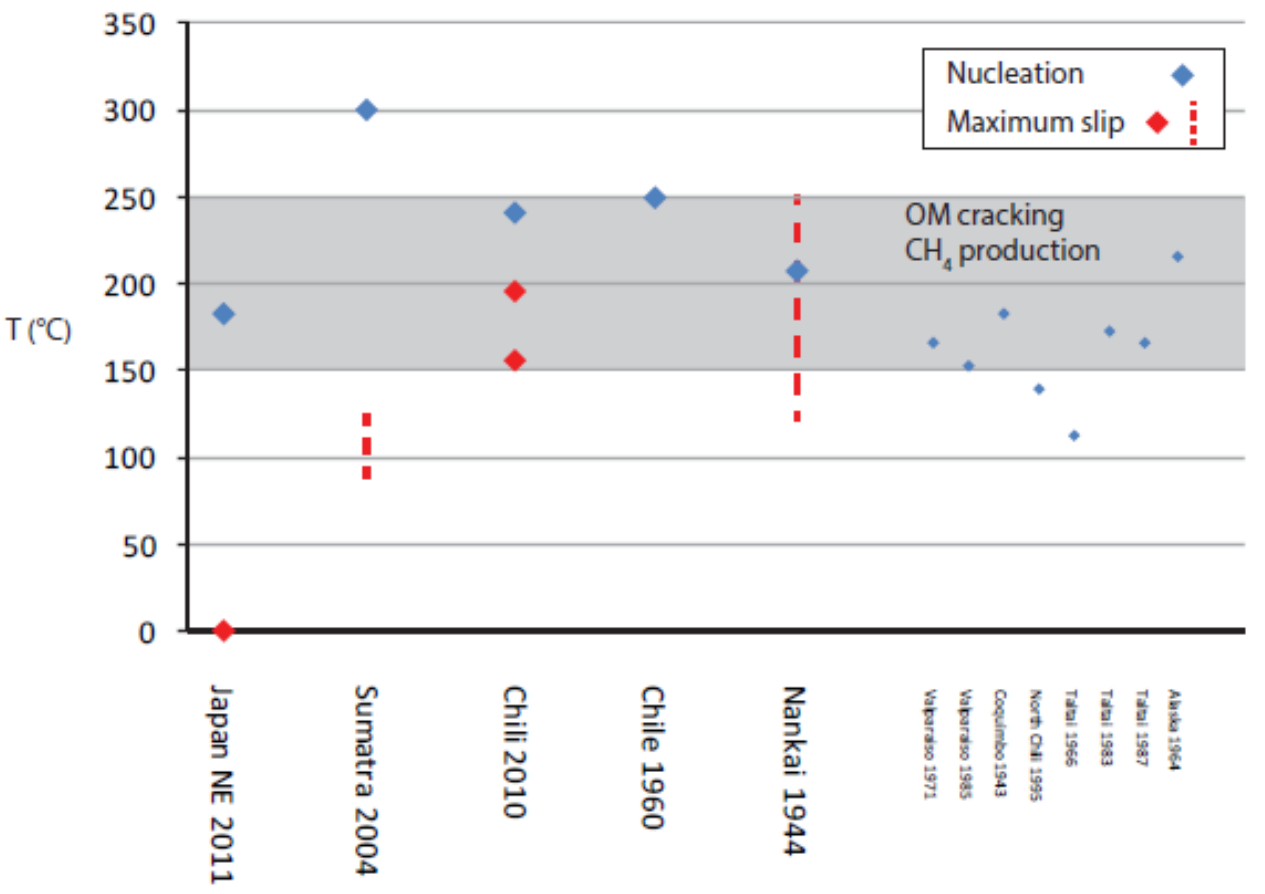

Figure 15: Comparison of the subduction zone mega-earthquakes temperatures characteristics with the T-range of OM thermal cracking and methane production for Type III OM (gray box) . Temperature of the slip maximum/nucleation for mega-earthquakes were determined using relocalized hypocenters/slip zones and thermal models according to: Japan NE 2011 - (Lay et al., 2011; Suzuki et al., 2012; Wada and Wang, 2009), Sumatra 2004 - (Engdahl et al., 2007; Rhie et al., 2007; Syracuse et al., 2010; Wada and Wang, 2009), Chile 1960 and 2010 - (Vigny et al., 2011; Völker et al., 2011), Nankai 1944 - (Marcaillou et al., 2012), other south american earthquakes and Alaska 1964 - (Oleskevich et al., 1999). For Sumatra 2004, the T of the zone of maximum coseismic slip is lower than $125^{\circ} \mathrm{C}$, while for Nankai 1944 , the maximum coseismic slip is defined as >1m. For Maule earthquake (Chile 2010), two patches of maximum slip were identified (Vigny et al., 2011). 


\section{Highlights}

Thermal cracking of organic matter in suduction zones leads to fluid overpressure

Fluid at depth is a mixture of immiscible methane-rich and water-rich fluids

Significant fluid overpressure involves detrital organic matter in sediments

No overpressure in ocean-ocean subduction zones

Fluid overpressure possibly favors earthquake generation 